\title{
PLANNING FOR A COASTAL CITY: SAN CLEMENTE'S LOCAL COASTAL PROGRAM
}

\author{
A Professional Project \\ presented to \\ California Coastal Commission, \\ City of San Clemente, and \\ the Faculty of California Polytechnic State University, \\ San Luis Obispo
}

\author{
In Partial Fulfillment \\ of the Requirements for the Degree \\ Master of City and Regional Planning
}

by

Atousa Zolfaghari

May 2013 
(C) 2013

Atousa Zolfaghari

ALL RIGHTS RESERVED 
TITLE:

AUTHOR:

DATE SUBMITTED:

COMMITTEE CHAIR:

COMMITTEE MEMBER:

COMMITTEE MEMBER:

COMMITTEE MEMBER:
Planning for a Coastal City: San Clemente's Local Coastal Program

Atousa Zolfaghari

May 2013

Dr. Kelly Main, Assistant Professor, City and Regional Planning

Chris Clark, JD, Lecturer, City and Regional Planning

Jeff Hook, Principal Planner at City of San Clemente

Jim Pechous, City Planner at City of San Clemente 


\begin{abstract}
PLANNING FOR A COASTAL CITY: SAN CLEMENTE'S LOCAL COASTAL PROGRAM
\end{abstract}

Atousa Zolfaghari

This professional project assesses current conditions and regulations within San Clemente's Coastal Zone, and provides recommendations to the City and California Coastal Commission through a draft Land Use Plan. The amended Land Use Plan will be included in the certified Local Coastal Program, which will govern decisions that determine the short and long-term conservation and use of coastal resources within San Clemente's Coastal Zone.

Local Coastal Programs (LCPs) are planning guides used by local governments for development within the Coastal Zone. They contain goals and policies for development and protection of coastal resources throughout coastal cities and counties in California. LCPs identify appropriate locations for various land uses based on their goal of environmental and sustainable development and growth. Each LCP contains two components: a Land Use Plan (LUP) and an Implementation Plan (IP). Generally, the LUP contains the Coastal Element of the General Plan and provides the overall goals and policies that protect a City's coastal resources. The IP is intended to implement the goals and policies in the City's Land Use Plan and includes sections of the City's Zoning Ordinance, and Specific Plans within the Coastal Zone. Although each LCP is unique to a coastal community, they all need to maintain statewide regulations through conformity with the Coastal Act requirements.

After the California Coastal Commission (CCC) has approved an LCP, the coastal permitting authority over most new development is transferred to the local government, but the CCC retains permanent coastal permit jurisdiction over all proposed development on public trust lands, tidelands, and submerged lands. The CCC will also review and approve any amendments to previously certified LCPs. 


\section{ACKNOWLEDGMENTS}

I would like to extend my sincere thanks to all those who helped me in the professional project process. First and foremost, I would like to thank my clients, Jeff Hook and Jim Pechous, for introducing me to the project and for their helpful comments and guidance the past year. Their confidence and trust in my abilities was essential to my success.

I would also like to thank my committee chair, Kelly Main, and committee member, Chris Clark, for their enthusiasm and support throughout the year, which was essential to my success.

Additional thanks to my Bungalove roommates, both past and present, for their love and encouragement over the past two years. 


\section{TABLE OF CONTENTS}

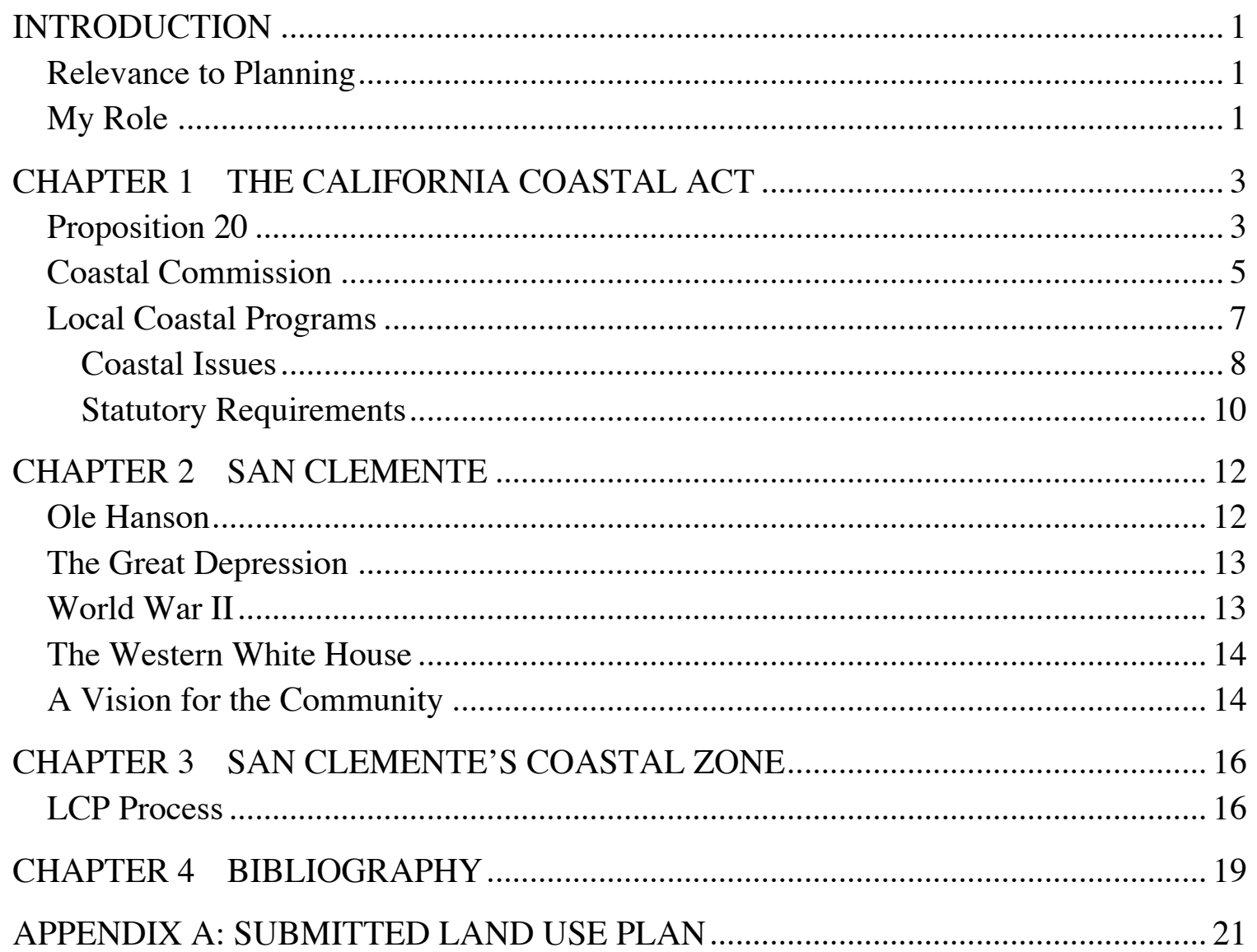




\section{INTRODUCTION}

\section{Relevance to Planning}

Researching Coastal Zone management and creating an LCP is a planning process. I have been in collaboration with stakeholders throughout the nine-month process, and held various meetings in San Clemente to gain staff input.

According to the Coastal Act of 1976, "each local government lying, in whole or in part, within the coastal zone shall prepare a local coastal program for that portion of the coastal zone within its jurisdiction" (Section 30500). Coastal cities that do not have an adopted LCP do not contain any permit authority over the section of their community that lies within the Coastal Zone. It is important to San Clemente's staff that they contain permit authority throughout all of their city boundaries, and this LCP will be a tool to guide them in that direction.

\section{My Role}

My role with the City of San Clemente consisted of creating a draft Land Use Plan for the Coastal Zone, consistent with the new General Plan and with State Law. I was originally hired by the City to begin this process, but decided to continue my work with the City and this project throughout the academic year.

The City prepared a draft Local Coastal Program over twenty years ago, but the documents was never completed or approved by the California Coastal Commission. As part of the General Plan update (which is in the final stages), the City is updating its Coastal Element and Land Use Element. With these changes, I was assigned to update the previous draft LCP and secure State approval. My process consisted of the following: 
1. Update the content and organization of the LCP for consistency with State law

2. Rewrite for clarity and brevity, as needed

3. Add graphics

The overall purpose of my project is to achieve State approval of a new Local Coastal Program that will allow the City greater autonomy in carrying out its coastal land use goals and programs. Also, to update the City's specific plans in anticipation of the new General Plan to be adopted in 2013, based on the City Council's preferred land use alternative.

Because the updated General Plan is not as detailed as the Coastal Commission staff would like the Land Use Plan to be, it will be a an independent document, rather than the City's Coastal Element (which was the original plan). The new format of the LCP will have an LUP that is adopted separately from the General Plan. The LUP will contain the policies from the Coastal Element of the City's General Plan plus addition information including development standards and policies, as requested by the Coastal Commission staff. The draft LUP was submitted to the Coastal Commission in March 2013 for review.

I have also created a draft Implementation Plan for the City, but it will not be submitted until staff receives Coastal Commission comments on the LUP to ensure consistency throughout both plans. 


\section{Proposition 20}

On November 7, 1972, California voters passed Proposition 20, the California Coastal Zone Conservation Act. This proposition launched and funded the California Coastal Commission to plan for and regulate new development and strong policies to protect public access to and along the shoreline.

The proposition stemmed from the controversy surrounding the planned coastal community of Sea Ranch in Sonoma County. Developer and architect Al Boeke initially envisioned a community that would preserve the area's natural beauty, but the plan eventually grew to include 10 miles of the Sonoma County coastline that would have been reserved for private use. Similar coastal projects decreasing public access along the coast were also proposed, prompting the formation of activist groups.

The group that placed Proposition 20 on the ballot was the Coastal Alliance, a grassroots campaign organization made up of more than 700 environmental, civic and labor organizations. Winning with more than $55 \%$ of the vote was a huge accomplishment for the Coastal Alliance, advocating their commitment to protecting the coast through comprehensive planning and regulation of coastal development.

The official ballot summarized the proposition as follows:

- Creates State Coastal Zone Conservation Commission and six regional commissions 
- Sets criteria for and requires submission of plan to Legislature for preservation, protection, restoration and enhancement of environment and ecology of coastal zone

- Establishes permit area within coastal zone as the area between the seaward limits of state jurisdiction and 1000 yards landward from the mean high tide line, subject to specified exceptions

- Prohibits any development within permit area without permit by state or regional commission

- Prescribes standards for issuance or denial of permits

- Appropriates five million dollars for the period of 1973 to 1976

The proposition originally allotted a four-year program to regulate development and directed the new Coastal Commission to draft a long-range plan to guide future conservation and development in the Coastal Zone, using maximum public input. Hundreds of public meetings were held, and in late 1975, the California Coastal Plan was submitted to the legislature and became the foundation for the California Coastal Act of 1976. This confirmed the state's goal in providing public access to the coast for all residents, and protecting coastal resources. The Act provided guidelines for coastal development with priority to commercial fishing, boating and other visitor-serving establishments.

While Proposition 20 allotted permit authority to the Coastal Commission for four years, the California Coastal Act of 1976 extended the Coastal Commission's authority indefinitely. Proposition 20 stated that the Coastal Commission "would terminate on the 
91st day after final adjournment of the 1976 Regular Session of the Legislature."

However, in 1976, "the legislature welded it in place with the California Coastal Act of 1976" (California Proposition 20).

\section{Coastal Commission}

Based on the California Coastal Act of 1976, the Coastal Commission is tasked with the following responsibilities within the Coastal Zone:

- coastal resource protection

- shoreline public access and recreation

- lower cost visitor accommodations

- cultural and historic resources

- terrestrial and marine habitat protection

- visual resources

- landform alteration

- protection of agricultural lands

- commercial fisheries

- industrial uses

- water quality

- offshore oil and gas development

- transportation

- development design

- power plants

- ports 
- public works

The mission of the California Coastal Commission is to "protect, conserve, restore, and enhance the environmental and human-based resources of the California coast and ocean for environmentally sustainable and prudent use by current and future generations" (Coastal Commission, 2007). The Coastal Commission is an independent quasi-judicial state agency that consists of twelve members appointed by the Governor, the Senate Rules Committee, and the Speaker of the Assemply. These members contain permit authority along California's 1,100 miles of shoreilne. The six Regional Commissions consist of:

- North: Del Norte, Humboldt, and Mendocino Counties

- North Central: Sonoma, Marin, and San Francisco Counties

- Central: San Mateo, Santa Cruz, and Monterey Counties

- South Central: San Luis Obispo, Santa Barbara, and Ventura Counties

- South: Los Angeles and Orange Counties

- San Diego: San Diego County

The Commission's funding has risen 21 percent since 1980 from $\$ 13.5$ million to $\$ 16.3$ million, while the full-time staff fell from 212 in 1980 to 125 in 2010 . There are currently 11 enforcement officers to investigate violations along the California coastline.

To accomplish the goals of the Coastal Commission, the Coastal Act established a unique partnership between the state and local governments that gave local governments the authority to regulate new coastal development under Local Coastal Programs approved by the Coastal Commission. 


\section{Local Coastal Programs}

According to the Coastal Act policies, development in the Coastal Zone requires a coastal permit from the Coastal Commission or local government through the Local Coastal Program (LCP). In order to obtain Coastal Zone permit authority, local governments are required to prepare Local Coastal Programs for the Coastal Zone portion of their jurisdiction. Once an LCP has been drafted, it is submitted to the Coastal Commission for comments and approval. The Coastal Commission must review the plan to ensure consistency with the Coastal Act before handing over Coastal Zone authority to local jurisdictions. Once an LCP is approved, the Commission's regulatory authority over issuing coastal development permits is turned over to the local government, while maintaining limited appeal authority. There are some cases, like areas with public trust lands, where the Commission retains jurisdiction in the Coastal Zone even with a certified Local Coastal Program. For jurisdictions with certified LCPs, the Commission does not retain permit authority. Instead, the Commission is responsible for reviewing LCP amendments, or reviewing coastal development permits issued by local agencies which have been appealed.

A Local Coastal Program acts as a General Plan for a local jurisdiction's Coastal Zone, and is composed of a Land Use Plan and an Implementation Plan. A Land Use Plan contains goals, policies, and implementaion actions for specific coastal land uses contained in the Coastal Zone. The Land Use Plan is often the Coastal Element of the local government's General Plan. The Implementation Plan further details how the policies contained in the Land Use Plan will be implemented, and includes a part of the City's zoning code. 


\section{Coastal Issues}

California's coast faces many challenges. LCPs address these challenges, along with those specific to the local jurisdiction, and have become a vital part of California's Coastal Zone management program. Because new coastal issues are arising over time, LCPs must constantly be updated to protect and enhance the coast (Bobo \& Shulman, 80). In the past decade alone, significant changes have occurred that directly affect the health of the coast. The population of Coastal Zone residents has increased, and changing development patterns are just a few issues in California which have impacted public access and coastal resource preservation. Global warming and sea-level rise are identified state concerns that all Local Coastal Programs must address in their Land Use Plans (California Coastal Commission).

On April 3, 2007, the Coastal Commission created an LCP update guide, which informed local governments of new issues that must be addressed in LCPS updated or created after 2007. Specific new concerns that should be addressed in updated LCPs include the following:

- Implementing the California Coastal Trail - the California Coastal Trail was completed in January, 2003 and has enhanced pedestrian public access and recreation along the coast.

- Temporary coastal events - these events may impede on public access, and must be addressed and mitigated to make sure public use is not denied.

- Protecting public parking - the Commission generally doesn't encourage excess public parking, but many local jurisdictions have shown a need for public parking to encourage public access. 
- Expanding alternative modes of transportation - to protect and enhance air quality in the coastal zone, alternative modes of transportation should be included.

- Time restrictions and user fees - to ensure people of all incomes have equal accessibility to the coast, limit user fees and manage time restrictions.

- Avoiding and mitigating beach encroachments - to ensure maximum public access, LCPs should include measures (or programs) to ensure that development avoids or minimizes and mitigates encroachment on beaches. The updated LCP should not allow new private development to encroach onto public beaches.

- Avoiding private impediments to beach access - public access is adversely affected by "private beach" and "private parking" signs, and should be mitigated in LCPs.

- Comprehensive beach management - management measures help address many issues concerning the beach, including access, recreation, facility upgrades, and protection of sensitive habitats and agricultural lands.

- Condominium hotels and timeshares - accommodations must ensure protection of public visitor-serving facilities as a priority use.

- An updated water quality and protection component - sea level rise is a major concern for all coastal communities, and must be addressed with mitigation plans along with the protection and enhancement of marine and coastal water quality.

- Marblehead Coastal, a 248-acre, specific plan area, has now been included in the LCP.

The Coastal Commission understands a community's need to grow and thrive, but sets these guidelines to protect coastal habitats and resources. The guidelines are intended to 
support the shared goal of meeting Coastal Act policies in the face of change, while recognizing that it is impossible to address every issue a coastal community may face.

\section{Statutory Requirements}

The Coastal Act of 1976 is intended to assure that coastal areas of California are developed in a manner responsive to public objectives. The Act establishes these objectives as coastal policies, and provides guidelines for municipal governments to reevaluate their coastal area planning and zoning concepts to achieve consistency with the Act.

The Act declares that "to achieve maximum responsiveness to local conditions, accountability and public accessibility, it is necessary to rely heavily on local government and local land use planning procedures and enforcement in carrying out the state's coastal objectives and policies" (California Coastal Act, 26). To accomplish this, each local government lying wholly or partly within the Coastal Zone is directed to prepare an LCP for its portion of the Coastal Zone.

Chapter three of the Coastal Act consists of a policies and a guide that discusses the ten key issues that must be addressed in each LCP. These are:

- Public Access

- Recreation and Visitor Serving Facilities

- Water Quality

- Natural Resources

- Agricultural Resources

- Planning and Locating New Development 
- Scenic Resources

- Coastal Hazards

- Shoreline Erosion and Protective Structures

- Energy, Industrial and Other Coastal Development

According to the Coastal Commission, an LCP shall consist of "a local government's land use plans, zoning ordinances, zoning district maps and implementing actions which, when taken together, meet the requirements of, and implement the provisions and policies of the Coastal Act at a local level" (City of San Clemente Coastal Element, 1995). These components make up the Land Use Plan and Implementation Plan of the LCP. 


\section{CHAPTER 2 SAN CLEMENTE}

San Clemente is a city in Orange County, California with a population of 63,522 , according to the 2010 census. Located on the California Coast, San Clemente lies midway between Los Angeles and San Diego at the southern tip of the county, and is known for its ocean, hill, and mountain views, a pleasant climate and its Spanish Colonial style architecture. San Clemente's city slogan is "Spanish Village by the Sea". The City has a total area of 19.5 square miles $\left(51 \mathrm{~km}^{2}\right)$.

\section{Ole Hanson}

"I vision a place where people can live together more pleasantly than any other place in America. I am going to build a beautiful city on the ocean where the whole city will be a park; the architecture will be of one type, and the homes will be located on sites where nearly everyone will have his view preserved forever" (Walker, 4).

The City of San Clemente was founded by Ole Hanson, a former Mayor of Seattle, Washington on December 6, 1925. In the early 1920s, Hanson formed a partnership with banker Hamilton H. Cotton and purchased 2,000 acres of land on the South Orange County Coast. Hanson was known as a great visionary, with a dream of creating a Spanish village by the sea.

On February 21, 1928, San Clemente was incorporated as a city. The incorporation became effective on February 28, 1928, officially marking the dawn of city-hood for San Clemente.

Ole Hanson died in 1940, but as a lasting tribute to San Clemente's Founder, December $6^{\text {th }}$ of each year is designated "Ole Hanson Day" in San Clemente. 


\section{The Great Depression}

The first year as an incorporated city proved San Clemente to be a thriving community. But by October of 1929, the stock market crashed and banks failed, leading to the Great Depression. The impact of the Depression on San Clemente was severe. Many residents lost their jobs or sources of income, bank foreclosed on many properties, and local businesses failed. Construction and development was the main industry at the time and with the severe decline in building, the City's economy also plummeted (much like the national economy). The City lost its tax base and was forced to retrench, eliminating several positions. Many people, including Ole Hanson, found themselves compelled to relocate, reducing the population from 1,000 to 250 (Walker, 127).

Because of foreclosures and quitclaims, Bank of America owned an abundance of property in the City. Feeling that the architectural restrictions hindered marketing and development, the Bank petitioned the courts to have the clause requiring Spanish architecture removed from the sales agreements. The court ruled in favor of the bank, circa 1937, marking an end to the deed restrictions which required Spanish architecture.

\section{World War II}

The bombing of Pearl Harbor on December 7, 1941 brought a wave of local changes to San Clemente. Shortly after World War II began, the federal government established a need for a Southern California military base to train Marines and protect the coast. A 122,000 -acre lot just south of San Clemente was allotted to the Department of the Navy, which established the location as US Marine Corps Camp Pendleton, named after General Joseph Pendleton, a former Marine who served in several wars from 1878 to 1924 (Walker, 143). 


\section{The Western White House}

President Richard Nixon purchased Casa Pacifica (originally the Cotton estate) in San Clemente, which made the City well known throughout the United States. The property became known as the Western White House during the Nixon presidency, bringing national and international attention that carried with it both advantages and disadvantages for the City. San Clemente became well known and tourism increased; however, it became necessary to close a popular portion of the beach near Trestles, which resulted in high-profile helicopter and marine surveillance. President Nixon's legacy lives on. The San Clemente Historical Society established a local Nixon memorial in recognition of our most famous resident.

San Clemente has grown since the days of Ole Hanson, with its borders expanding inland toward the hills and its population growing from 1,000 persons in 1929 to 63,522 in 2010 (U.S. Census Bureau), with an estimated population of 70,000 by 2015 . The new residential projects will be accompanied by commercial and retail developments to provide for an economically balanced and stable community.

\section{A Vision for the Community}

A pivotal goal of the community is to maintain Ole Hanson's vision of a small-town village by the sea character. While containing a certified LCP is very important to the City, the Coastal Commission and City have conflicting goals. The main goal of the Coastal Commission is to ensure public access to the coast through visitor-serving facilities and tourism. While San Clemente understands the need for equal access, the community strives to retain its small town character. The essence of San Clemente is it's Spanish village by the sea character, and residents have made it very clear that they do 
not want their city to become a major tourist destination. This conflict of goals created a challenge in producing the Land Use Plan, and must be negotiated between the City and Coastal Commission through a certified LCP (City of San Clemente Housing Element). 
San Clemente's Coastal Zone includes natural, cultural and urban resources. The community shares a common goal of preserving and enhancing San Clemente's coastline, coastal access, and recreational attractions, while maintaining the small town village character of the community (City of San Clemente Coastal Element).

\section{LCP Process}

The LUP was certified with suggested modifications on October 6, 1981. Though this plan was certified, there were few unresolved issues, including public access and environmental protection of the canyons. A resubmitted LUP was certified with suggested modifications by the Commission on May 15, 1987, but this certification lapsed after six months. A second resubmitted LUP was certified and submitted on May 11, 1988. The City's General Plan update was then prepared and the Pier Bowl Master Plan was finished. The City eventually submitted an updated draft LUP to Commission staff and a formal LUP amendment was approved in 1995. This LUP also served as the Coastal Element of San Clemente's General Plan.

The Implementation Plan (zoning portion) was denied on October 6, 1981. Revised zoning was submitted in 1996 and was deemed incomplete. The LCP Implementation Plan was approved with suggested modifications on April 10, 1998. However, the certification has since lapsed. The LCP Implementation Plan was resubmitted on June 3, 1999, but was withdrawn on October 5, 2000 by city staff. The Commission found the Implementation Plan to be inconsistent with the Land Use Plan, requiring too many changes and edits for approval. 
Along with the additional components required in an updated LCP as of 2007, San Clemente will also be including third specific plan. The Marblehead Coastal Specific Plan was created on October 6, 1981, and includes 192 acres. Formerly known as the Reeves Ranch, the main issues are environmentally sensitive habitat areas, alteration of natural landforms, visual resources, recreation and visitor-serving facilities and hazard areas. While the issues related to this area were addressed through Commission's approval with conditions of permit 5-03-013 on April 9, 2003, this area was not included in the current Land Use Plan, but will be implemented in the updated Plan.

The City has a long history at working on the development and certification of a LCP. Provided below are some key millstones:

1981 The LUP was certified by Coastal Commission with suggested modifications on October 6, 1981. Unresolved issues include public access and environmental protection of the canyons however the City did not peruse a revised submittal until 1987.

1982 Coastal Commission approved an exclusion order that allows development that was determined not to have any potential impact on Coastal Resources to not require a $\mathrm{CDP}$.

1988 The Coastal Commission certified the City's Coastal Land Use Plan but did not certify the Implementation Plan finding that the IP did not adequately implant the LUP's goals and policies.

1993 The City completed a comprehensive update to the City General Plan. 
1995 The City completed a comprehensive update to the City LUP to be consistent with the General Plan.

1997 The City developed an Implementation Plan

1998 The Coastal Commission reviewed the City IP and provided a list of suggested modifications into the plan for inclusion.

1999 The City Council approved the Coastal Commission suggested modifications

2000 The Coastal Commission reviewed the amended IP which incorporated the suggested modifications and found it inconsistent with the LUP. Note: The reason the IP was not certified was due to a change in the make up of the Coastal Commissioners. The new Commission placed a higher standard on the protection of natural coastal resources, particularly water quality.

2000 The City withdrew its IP application to avoid a denial and to decide whether to proceed with the IP. The IP was placed on hold indefinitely.

2002 The City adopted the Storm Water Runoff Control Ordinance.

2006 The City is processing a General Plan and Coastal Land Use Plan Amendment to meet the requirements of the Orange County Storm Water Permit that includes measures that will improve water quality.

2012 The City hired Atousa Zolfaghari as an intern to create an updated draft LCP 
Bobo, B. \& Shulman, D. (1977). Managing california's coast: The problem of housing distribution. California Management Review (Pre-1986), 20(000001), 74-80.

California Coastal Act. (1977). Urban Design, 8(4), 26-27.

California Coastal Commission. (2007). Retrieved at http://www.coastal.ca.gov

California Coastal Zone Conservation Commissions. (1975). California coastal plan. Sacramento: Documents and Publication Branch.

California Proposition 20, Coastal Initiative Collection. Retrieved at http://www.oac.cdlib org/findaid/ark:/13030/kt500037jx/

City of San Clemente. “General plan: coastal element”. San Clemente, 1995.

Fischer, Michael L. (2007). California's coastal program: larger-than-local interests built into local plans. Journal of American Planning Association. Volume 51, Issue 3, 1985.

San Clemente Chamber of Commerce. "San clemente: the spanish village by the sea". San Clemente, 2007.

U.S. Census Bureau; 2010 Census of Population and Housing, Summary File 1; Table DP-1; generated by Atousa Zolfaghari; using American FactFinder; http://factf inder 2.census.gov/faces/tableservices/jsf/pages/productview.xhtml?pid =DEC _10_SF1_SF1 DP1\&prodType=table; (20 April 2013). 
Walker, Doris I. "The heritage of san clemente". Published by The Heritage of San Clemente Foundation. 2000. 
APPENDIX A: SUBMITTED LAND USE PLAN 


\section{CITY OF SAN CLEMENTE}

LOCAL COASTAL PROGRAM

\section{LAND USE PLAN}

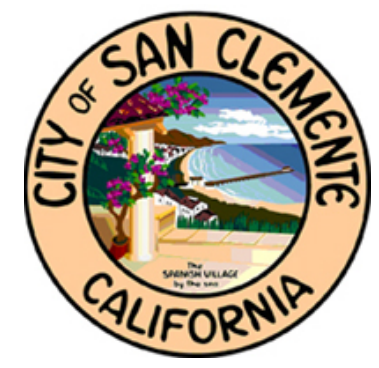

March 12, 2013 


\title{
LOCAL COASTAL PROGRAM
}

\author{
LAND USE PLAN
}

REVIEW DRAFT

City Manager, George Scarborough

Community Development Director, James Holloway

City Planner, Jim Pechous

Principal Planner, Jeff Hook AICP

Planning Intern, Atousa Zolfaghari

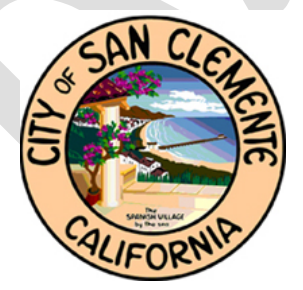

City of San Clemente

Community Development Department

910 Calle Negocio, Suite 100

San Clemente, CA 92673

(949)361-6100 


\section{TABLE OF CONTENTS}

\section{CHAPTER 1: INTRODUCTION}

\subsection{Purpose \\ 1.2 Goals \\ 1.3 Policies \\ 1.4 How to Use This Plan \\ 1.5 The Coastal Act}

\section{CHAPTER 2: COASTAL ZONE AREA DESCRIPTION}

2.1 Introduction

2.2 Environmentally Sensitive Habitat

2.3 Cultural Resources

2.4 Access Routes

2.5 Shoreline Access

2.6 Urban Setting

2.7 Recreational Resources

\section{CHAPTER 3: GOALS AND POLICIES}

3.1 Overview of Coastal Policies

3.2 Coastal Land Use Goals and Policies
A. Residential
B. Commercial and Mixed Use
C. Industrial Land Use
D. Public and Institutional Land Use
E. Open Space Land Use
F. Special Districts
G. Planning and New Development

3.3 Coastal Access Goals and Policies
A. Circulation/Transportation/Parking Policies
B. Coastal Access Policies

3.4 Recreation and Visitor-Serving Facilities Goals and Policies
A. Coastal Visitor-Serving Facilities Policies
B. Recreation Policies

3.5 Coastal Visual and Historic Resources Goals and Policies
A. Visual Resource Policies
B. Historic Resource Policies

3.6 Water and Marine Resources Goals and Policies

3.7 Environmentally Sensitive Habitat Goals and Policies 


\section{CHAPTER 4: IMPLEMENTATION MEASURES}

4.1 Overview of Coastal Implementation Measures

4.2 Land Use

4.3 Shoreline Access

4.4 Recreational and Visitor Serving Facilities

4.5 Visual and Historic Resources

4.6 Water and Marine Resources

4.7 Environmentally Sensitive Habitat

4.8 General Implementation

CHAPTER 5: DEFINITIONS

\section{TABLE OF FIGURES}

Table 1.1: $\quad$ Land Use Plan Organization Matrix

Figure 2.1: Coastal Zone Boundaries

Figure 2.2: Coastal Canyons

Figure 2.3: Coastal Reefs

Figure 3.1: Coastal Land Use

Table 3.1: Coastal Land Use Classifications

Figure 3.2: Coastal Access Points

Table 3.2: Hotels, Motels and Inns within the Coastal Zone 


\section{CHAPTER 1: INTRODUCTION}

\subsection{Purpose}

San Clemente's coastline provides many benefits. It is the main influence on our community's identity, it creates a desirable climate and living environment, it provides stunning scenery and recreational opportunities, it attracts tourists and businesses, and provides diverse marine and shore habitats that are home to many plant and animal species. Coastline protection and land use often involve competing interests and needs. These interests must be carefully balanced to ensure long-term coastal protection and an environmentally sustainable future for our community.

The Coastal Zone is a distinct geographic area defined and governed by the California Coastal Act, which establishes legislative requirements for the use and development in the Coastal Zone. This Land Use Plan fulfills a portion of the requirements of state law and, in combination with the Implementation Program, which includes the zoning ordinance, specific plans and other implementing documents, comprises San Clemente's Local Coastal Program (LCP).

The Coastal Act defines an LCP as “a local government's land use plans, zoning ordinances, zoning district maps, and other implementing actions, which, when taken together, meet the requirements of, and implement the provisions and policies of [the Coastal Act] at the local level." The City's LCP consists of: 1) a Land Use Plan and 2) a Local Implementation Plan.

1. The Land Use Plan indicates the kinds, location, and intensity of land uses, the applicable resource protection and development policies, and, where necessary, a listing of implementing actions.

2. The Implementation Plan consists of the zoning ordinances, zoning district maps, and other legal instruments necessary to implement the land use plan.

After LCP certification, San Clemente will have final coastal development permit authority in most areas of the Coastal Zone. The Coastal Commission will retain original permit jurisdiction over areas such as submerged lands, tidelands, and public trust lands and appellate authority over local development approvals in specified geographic areas for major public works projects and major energy facilities. In authorizing coastal development permits, the City must make the finding that the development conforms to the certified LCP.

This document establishes the Coastal Land Use Plan portion of the Local Coastal Program, prepared in accordance with the California Coastal Act of 1976. The Coastal Land Use Plan sets forth goals, objectives, and policies that govern the use of land and water in the coastal zone within the City of San Clemente. 


\subsection{Goals}

In developing the goals for the Coastal Land Use Plan, the City has focused on the objectives set by the State Legislature for the Coastal Act. However, in a broader sense, we realize that the coast is a precious resource and a fundamental part of our identity. We have a deep and abiding responsibility for its long term care which transcends legal requirements. Accordingly, the primary goals for our Coastal Zone are to:

a. Sustain healthy natural habitats, natural resources, and the marine and shoreline environment;

b. Be accessible to residents and visitors;

c. Be a valued and cherished scenic resource; and

d. Reflect our cultural and historical identity;

e. Provide recreational and visitor-serving opportunities;

f. Be characterized by land uses and development that follow the City's Local Coastal Program and are consistent with the Coastal Act.

\subsection{Policies}

The policies stated in this chapter are directly related to the desired goals and the identified issues within the community, and are intended to achieve San Clemente's vision for the future. In general, the Coastal Policies address the following:

a. Provide for the appropriate mix and type of land uses which will attract visitors to San Clemente and serve the existing and future needs of the community;

b. $\quad$ Provide for the revitalization, adaptive reuse, and upgrade of deteriorated neighborhoods and districts;

c. Require new development within the Coastal Zone to be consistent with the policies of the California Coastal Act;

d. Provide and maintain a comprehensive and safe beach access network;

e. Provide and maintain recreational areas, recreational activities, and visitor serving facilities;

f. Protect, where appropriate, public view corridors and historic resources;

g. Provide and maintain a safe and healthy beach for the enjoyable utilization of the marine environments;

h. Protect and preserve, where possible, significant wildlife habitats which exist in the Coastal Zone;

i. Maintain San Clemente as a unique and distinctive place in southern Orange County and the greater region

Policy Intent

Plan policy provides for the preservation of the existing residential neighborhoods in the Coastal Zone. With the exception of the Marblehead Coastal area, residential growth is limited to infill development. Only the area located between Avenida Pico and Trafalgar 
Lane would realize any significant changes in density as existing medium and high density residential properties build out to their maximum unit densities.

\subsection{How to Use This Plan}

The Land Use Plan contains goals, policies, and implementing actions for specific coastal land uses contained in the plan. The Coastal Act contains coastal resources planning and management policies that address public access, recreation, marine environment, land resources, development, and industrial development. The Coastal Land Use Plan addresses these topics under the following chapters:

\begin{tabular}{|l|l|l|}
\hline \multicolumn{1}{|c|}{ Topic } & \multicolumn{1}{|c|}{ Section and Page } & \multicolumn{1}{c|}{ Coastal Act Reference } \\
\hline Introduction & Chapter 1 & Sections 30000-30012 \\
\hline Coastal Zone Area Description & Chapter 2 & Sections 30103, 30168 \\
\hline $\begin{array}{l}\text { Coastal Access and Recreational } \\
\text { and Visitor-Serving Opportunities }\end{array}$ & Chapter 3 & $\begin{array}{l}\text { Sections 30210-30214, 30220- } \\
\text { 30224, and 30252 }\end{array}$ \\
\hline $\begin{array}{l}\text { Sensitive Habitats, Natural } \\
\text { Resources, and the Marine } \\
\text { Environment }\end{array}$ & Chapter 4 & Sections 30230-30237, and 30240 \\
\hline Scenic and Cultural Resources & Chapter 5 & \\
\hline Coastal Hazards and Development & Chapter 6 & Sections 30251-30253 \\
& & Sections 30007, 30212.5, 30213, \\
& & $30221-30223,30235-30236$, \\
& & $30250,30252-30253,30255$, \\
& Chapter 7 & $30260,30262,30600$, and \\
\hline Definitions & & Sections 30100-30122 \\
\end{tabular}

Table 1.1: Land Use Plan Organization Matrix

Each chapter is divided into sections and subsections. Each section or subsection begins with the identification of relevant goals, followed by a narrative of the local setting and policies adopted by the City to address the requirements of the Coastal Act.

\subsection{The Coastal Act}

The California State Legislature enacted the Coastal Act in 1976 to ensure protection of California's coastline by regulating human land uses and development within the Coastal Zone. It also established the California Coastal Commission as the management and regulatory agency to protect and enhance Coastal Zone resources.

The basic goals of the Coastal Act are to:

1. Protect, maintain, and where feasible, enhance and restore the overall quality of the coastal zone environment and its natural and artificial resources. 
2. Achieve orderly, balanced utilization and conservation of coastal zone resources taking into account the social and economic needs of the people of the state.

3. Maximize public access to and along the coast and maximize public recreational opportunities in the coastal zone consistent with sound resources conservation principles and constitutionally protected rights of private property owners.

4. Give priority to coastal-dependent and coastal-related development over other types of development within the Coastal Zone.

5. Encourage state and local initiatives and cooperation in preparing procedures to implement coordinated planning and development for mutually beneficial uses, including educational uses, in the coastal zone.

\section{Local Coastal Program and Land Use Plan Benefits}

a. Promote sandy beaches for recreational and shoreline protective benefits;

b. Protect coastal recreation resources through sand retention and replenishment;

c. Improve maintenance of existing and new bluff retention devices (e.g., retaining walls, engineered fills, upper bluff devices) to minimize their scope, maximize the preservation of natural beach and bluff, for aesthetics and safety;

d. Recognize the benefits and importance of a wide sand beach, natural bluffs, surf breaks, and other recreational resources for residents, visitors and businesses;

e. Prevent new development in geologically unstable areas; and,

f. Restrict new bluff retention devices on the coastal bluffs unless all other reasonably feasible options for protecting bluff top principal structures are deemed infeasible, and when allowed, that they are as small as possible and aesthetically managed and maintained to minimize their impacts.

g. Potential for improved public safety.

h. Streamline permit approval process for bluff retention devices that meet certain reasonable pre-approved criteria;

i. Align applicable provisions of the City's land development policies and regulations and municipal code with the current requirements of state law through the adoption of the LCP;

j. Increase local control as the City will be authorized to approve projects in the coastal zone, in a streamlined manner, without a need for CCC hearing;

k. Protect City facilities and infrastructure over time;

I. Provide provisions to encourage visitor serving commercial uses;

m. Provide provisions to protect coastal access, public views, and enhance public parking near the beach;

n. Protect Coastal Zone biological resources, including California native plants, animals and environmentally sensitive habitat; 
o. Protect historic and archeological resources;

p. Create the framework for long term planning to address coastal erosion and sea level rise; and,

q. Potentially increase tax revenues resulting from establishment and maintenance of a wide sandy beach with an expected increase in tourism and visitor spending resulting in more Transient Occupancy Taxes (TOT), sales taxes, increased property values and increases in the local share of property taxes. 


\section{CHAPTER 2: COASTAL ZONE AREA DESCRIPTION}

\subsection{Introduction}

San Clemente's Coastal Zone includes natural, cultural, and urban resources. In order to develop a Land Use Plan that preserves and enhances San Clemente's ocean front, coastal access, and recreational attractions, it is important to identify these resources. This chapter identifies significant habitat areas, cultural resources, access and circulation routes, shoreline access points, the urban environment, and the recreational resources within the Coastal Zone.

\subsection{Environmentally Sensitive Habitat}

San Clemente is committed to restoring, preserving and enhancing marine resources and Environmentally Sensitive Habitat Areas (ESHAs), including wetlands, estuaries, riparian areas, sand dunes and other natural habitats in the Coastal Zone. "Environmentally sensitive habitat" means any ecosystem or habitat that has rare plant or animal life or is itself rare (see definitions in Chapter 5). An example of an environmentally sensitive habitat is the Coastal Sage Scrub plant community, which is not only environmentally important because it supports a variety of native plants and animals (including two rare species: the California Gnatcatcher and the Cactus Wren), but also because the habitat itself is becoming increasingly scarce. Environmentally sensitive habitat areas in San Clemente's Coastal Zone are limited to the few remaining undeveloped areas in the Coastal Zone. There are limited amounts of wetlands, riparian, native grasses, and coastal sage scrub on the 253 acre Marblehead Coastal site, an area of deferred certification. There are also eight coastal canyons within the urban areas of San Clemente's Coastal Zone that contain valuable open space and habitat. Many consist of coastal sage scrub and are designated as Environmentally Sensitive Habitat Areas. A comprehensive detailed assessment of biological resources within the Coastal Zone has not been completed. The approximate boundaries of the Coastal Zone are depicted in Figure2.1 below: 


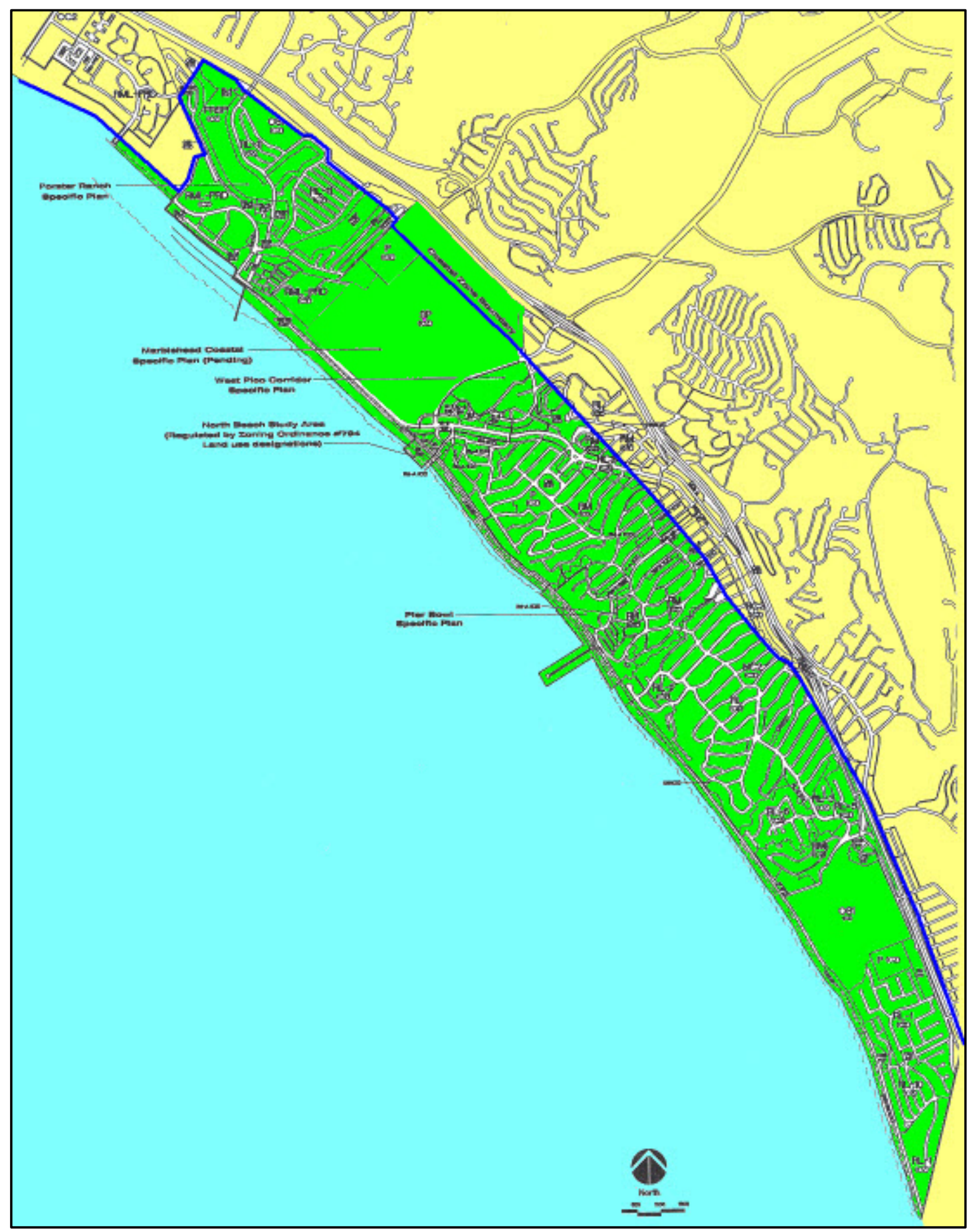

Figure 2.1: Coastal Zone Boundaries

\section{A. Coastal Bluffs and Canyons}

The coastal bluffs and canyons contain important natural habitat. The coastal canyons in San Clemente include; the two Marblehead Coastal Canyons, Palizada Canyon, Trafalgar Canyon, Toledo Canyon, Lobos Marinos Canyon, Riviera Canyon, Montalvo Canyon, and Calafia Canyon, as shown in Figure 2.2. The coastal bluffs in San Clemente run parallel to 
the coastline, interrupted only where coastal valleys and canyons intersect with the bluff face.

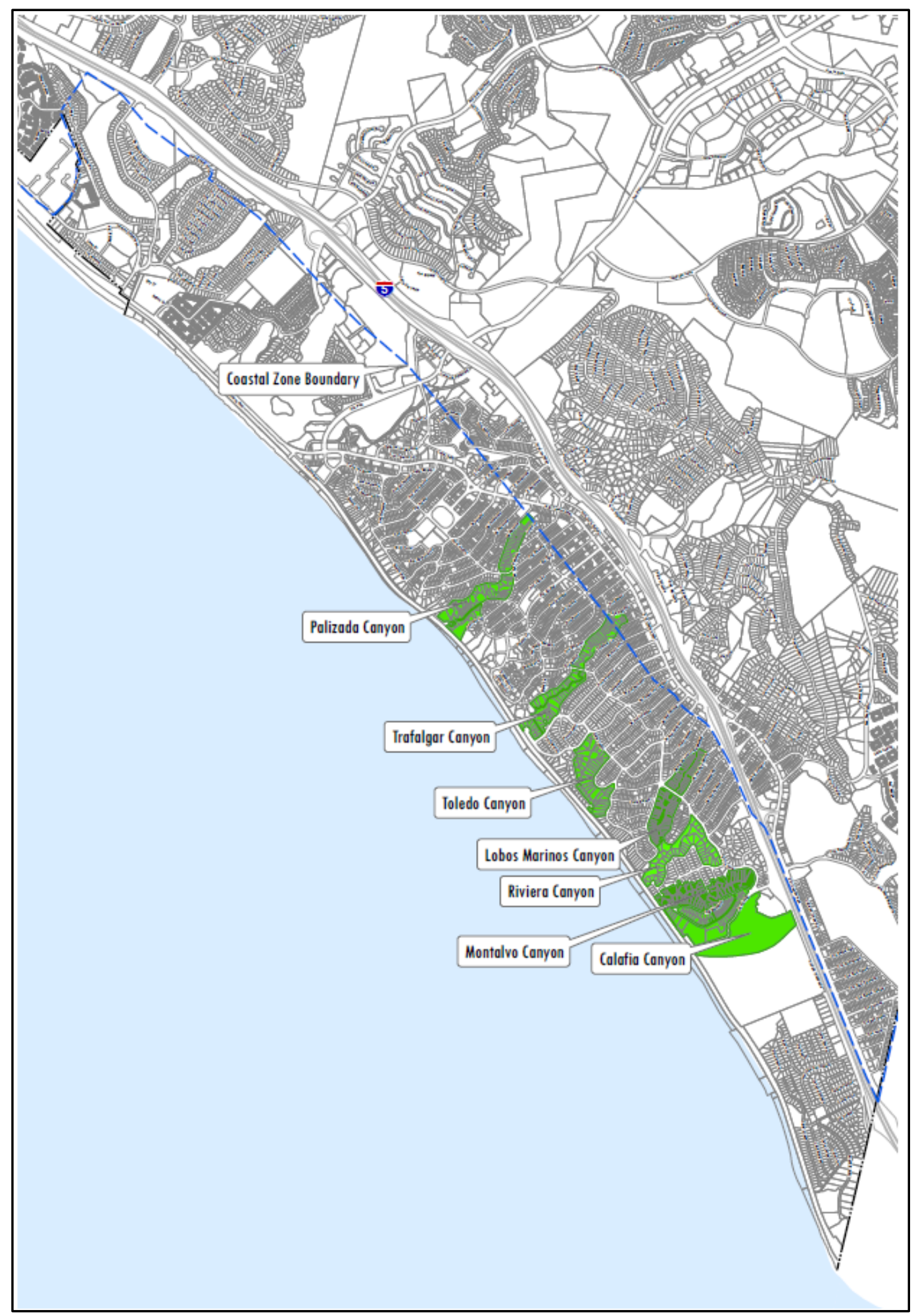

Figure 2.2: Coastal Canyons 
No rare or endangered plants or animals have been reported to exist within the coastal canyon habitat of San Clemente; however Blochman's Dudleya (Dudleya blochmaniae ssp. Bloch-maniae), a small succulent plant, is recognized by the California Native Plant Society as a rare plant which has been placed on its Inventory of Rare and Endangered Plants as Rank "1B.1", signifying it as being a rare endemic which is highly threatened in it limited habitat range. Populations of the Blochman's Dudley are known to exist along the bluffs on Marblehead Coastal and the San Clemente State Park. A preservation area has been established as part of the Marblehead Coastal development project.

The coastal canyons contain areas of flourishing coastal sage scrub as well as areas of coastal sage scrub intermixed with introduced vegetation. The native vegetation is drought tolerant and has deep root systems which help consolidate the surface soils on coastal canyons and coastal bluffs. There are no permanent water courses found within them; the principal source of water is runoff from excessive residential irrigation. The coastal bluffs support Coastal Bluff Scrub habitat, a variation or subset of Coastal Sage Scrub. This habitat is characterized by species especially tolerant of coastal conditions.

San Clemente's coastal canyons represent remnants of what was once a much larger habitat zone. Most of the City's coastal canyons (the only exception being the canyons located in Marblehead Coastal) are surrounded by residential development. The canyons have been cut off from larger habitat areas since the 1930s. Urbanization around the coastal canyons has led to the introduction of invasive non-native plants. In addition, the introduction of domestic animals has impacted the native fauna. The introduction of domestic dogs and cats from the surrounding urban areas impacts native bird, small mammal, and reptile populations. Despite these impacts, indicator species of Coastal Sage Scrub and Coastal Bluff Scrub plant communities are present. The primary environmental value of these habitat areas is that they represent an ever diminishing resource within urbanized portions of the coast.

The City's canyon and bluff preservation policies in the Municipal Code establishes requirements that prevent development from encroaching into the coastal canyons and bluffs and seeks to preserve wildlife corridors connecting these habitat "islands." These policies do not, however, fully protect the area's habitat from the effects of urban development and uses. The original integrity of the habitat in coastal canyons cannot be restored without linking the canyons to larger open space areas. Since creating wildlife corridors is not always a feasible option, restoration measures should be designed to enhance integrity of the habitat but should not be expected to return these areas to a state that existed prior to their isolation. Developing a successful restoration program for Coastal Sage Scrub and Coastal Bluff Scrub will be difficult because invasive plant species will continue to encroach into the canyons. To compound this problem, the canyons (with the exception of Marblehead Coastal and Calafia Canyons) are divided into hundreds of 
privately owned parcels, limiting the scope of any replanting plan to small fragments, rather than to the canyon as a whole.

\section{B. Topography}

Coastal bluffs are the vertical landform that lines most of the San Clemente coastline. The exceptions are the locations where streams have cut into the bluffs to form arroyos, canyons, or gently sloping valleys. The coastal bluffs and canyons are the prominent topographic feature within the Coastal Zone.

The origin or geomorphology of the coastal bluffs began, as the coastline was slowly uplifted from the ocean bottom during the Pliocene Epoch (1.6 million years ago). For this reason, marine fossils--similar to the species living in deep water today--show up in the Capistrano Formation (the marine deposit that makes up much of San Clemente's coastal bluffs).

The uplifted coastline has formed a steep bluff face. As the coastline emerged, coastal processes began to work- on the bluff face. The wave action then eroded away the bluff face and caused chunks of the bluff to break off, further steepening the face. In San Clemente, this erosional process has been interrupted by the development of the railroad and Pacific Coast Highway. There is no longer a wave undercutting effect on the bluff face. However, over steepened conditions of the bluff face exist as a direct result of the railroad and the Coast Highway. Large talus accumulations at the base of the bluff are periodically removed by maintenance crews whose purpose is to keep Pacific Coast Highway and the railroad open. Despite the elimination of natural processes, the coastal bluff remains a very prominent coastal feature.

The City's Land Use Plan and the Coastal Act contain policies for restricting development on coastal bluffs. There are some cases where the bluffs have been developed; however, this development occurred prior to the enactment of the Coastal Act. In other instances, the coastal bluffs have been graded in the interest of public safety, which is the reason for grading the Marblehead Coastal bluffs along the Coast Highway.

\section{Marine Environment}

San Clemente's coastal marine environment is limited to a continuous open coast sandy beach. Such beaches are sparsely populated by marine plants and animals in comparison with rocky shores. There is a large diversity of marine animals that can be found along San Clemente's shoreline: however, only six or seven common animals occur in any abundance on heavily surf swept sand beaches. Two of these animals, the Pismo Clams and Razor Clams, are now rare, due to the loss of sand, deterioration of water quality and human activities. Animals commonly found along the beach include the following: 
- Several species of isopods (e.g. pill bugs), including Alloniscus perconvexus and Tylos punctatus. These are air breathing animals one quarter inch to one inch long which make Mole-like burrows just beneath the sand surface.

- Sand crabs, Emerita analoga often occur in dense patches on the beach, with the largest individuals at the lowest level of the beach sand. They reach a maximum size of about 1-1/2 inches long. Spiny sand crabs, Blepharipoda occidentalis, also about 1-1/2 inches long, occur in the sub tidal region of sandy beaches, as do Archaeomysis maculate, a small shrimp like crustacean.

- Various clam species inhabit the sandy beach. These include Bean Clam, Donax gouldi, a small, wedge shaped clam averaging one inch in length; a Razor Clam, Sisiqua patula, a long (shell up to six inches) thin clam with fragile shining valves; and the Pismo Clam; Tivela stultorum, a large (up to seven inches or more in length), slow-growing species, which requires surf to survive.

- An elongate hydroid, Chytia bakeri, often found on Pismo Clams and Beans Clams, is the only hydroid found on exposed sandy beaches.

- Glycera sp., a Bloodworm, is a bright red opeliid worm about 1-1/2 to 2 inches long, which lives in a narrow band at about mid tide level. A Polychaete worm, Nainereis dendritica, which reaches a length of 12 inches is sometimes found at and below the lowest tide level.

The near shore and surf zone contain a number of fish species, many of which are popular as food. These species include Surf Perch, Corbina and Striped Bass. While not an intertidal form, the famous Grunion, Leuresthes tenius, a Smelt-like fish, is common in the local area. San Clemente is not a principal breeding ground for the Grunion.

In addition to the sandy beach and near shore habitats, there are numerous rock and clay finger reefs off the San Clemente shoreline that help form kelp forest and rich marine habitat, as shown in Figure 2.3. Three of the larger reef formations include:

- West Reef

The main portion of this rock reef is located approximately 1.700 feet off shore from Mariposa Point. There are a number of smaller rock formations located between the outer reef and the shoreline. These rocks are partially exposed during mean low tide. The reef is an occasional surf spot during larger swells and is known for its exceptional fishing and diving. This rock reef is an important habitat for a large number of marine species. The rocks located along the coastline are a good location to observe inter coastal species during extreme low tides.

- San Mateo Rocks 
These rocks, with a total exposed surface area at mean low tide of approximately 14,000 square feet, are located 2,400 feet offshore, opposite the Riviera storm drain. This is an important habitat area, supporting an extensive array of marine life. California Sea Lions, Zalophus Californianus, are often observed basking themselves on the rocks. The San Mateo Rocks are relatively undisturbed because wave and tidal action make it extremely difficult to approach them.

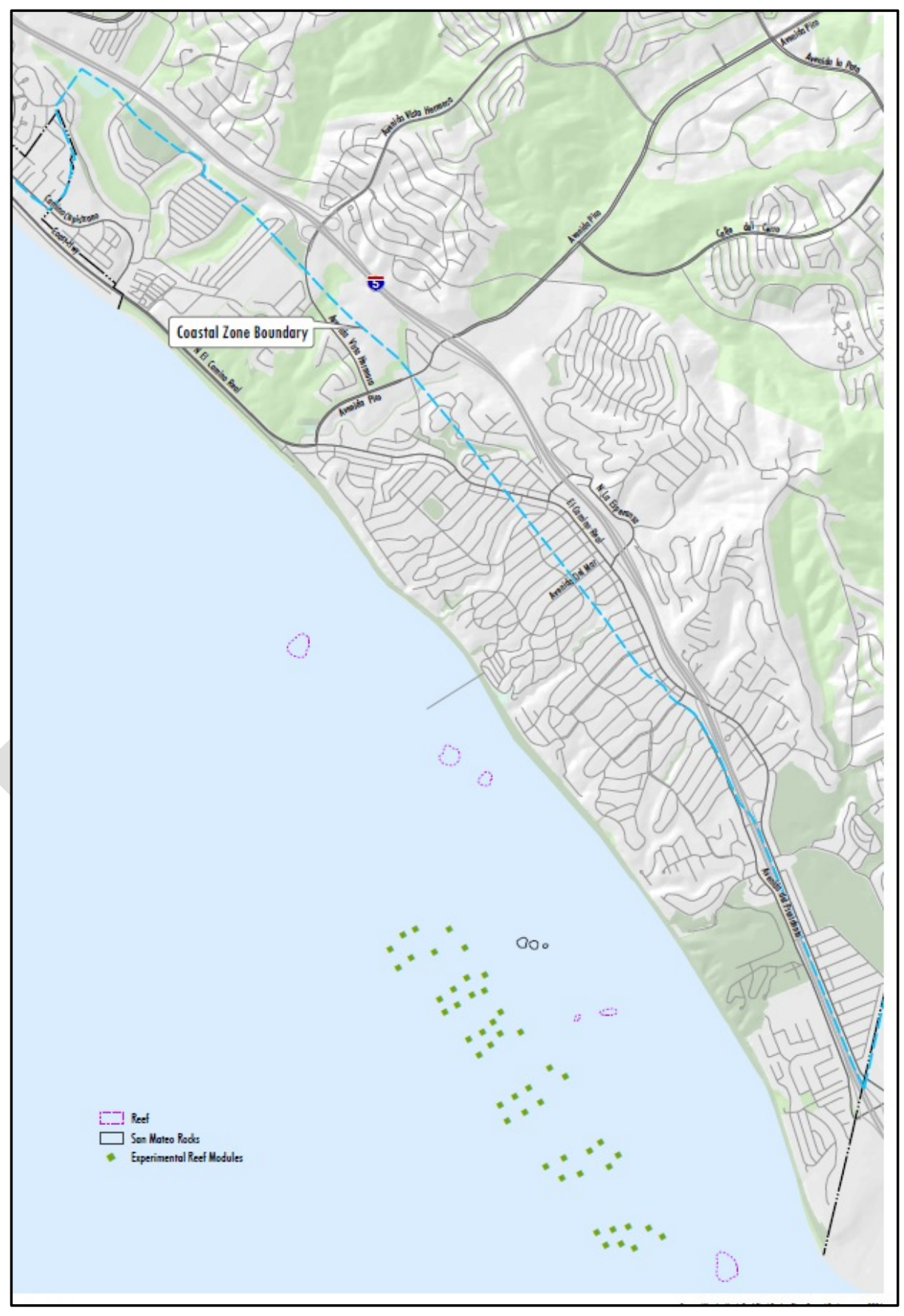

Figure 2.3-Coastal Reefs 
- Pier Pilings and Artificial Reefs

The San Clemente Pier wharf pilings form a distinctive habitat area. Pilings are of interest to students of marine biology because they clearly demonstrate life

- Zones of the near shore environment. There is an artificial reef located along both the north and south sides of the Municipal Pier. The pilings and artificial reef create a living environment for both marine plants and animals, which, in turn, help to make the pier a good place for fisherman.

Water in the San Clemente Coastal Zone serves a variety of purposes: it is a habitat for marine life, a recreation and visual resource, and a recipient of storm runoff. Assuming current conditions persist, existing plant and animal life along the sandy beach can probably maintain themselves indefinitely. It is questionable whether Pismo and Razor Clams can ever be re-established within the intertidal zone as long as heavy recreational use, dramatic shifts (erosion and accretion) of sand and pollution continues. Neither of these animals is rare or endangered 'or unique to the San Clemente Area.

The City's Coastal Zone is primarily urban in nature. As such, the water and marine resources in the area are impacted by pollutants normally associated with urban activities and land uses. Nuisance and storm water runoff is the principal source of pollutants discharged into the ocean within San Clemente's Coastal Zone. The list of potential pollutants is quite long and includes fertilizers, pesticides, vehicle hydrocarbons, greases, oil, rubber, plastics, asbestos, paint and metal fragments, bacterial organisms, and coarse litter, all of which can enter coastal waters through storm drains and flood control channels. In addition, the SERRA sewage outfall, located north of the City's Coastal Zone at Capistrano Beach, contributes organic material, bacteria, viruses, and possibly toxic substances. The San Onofre Nuclear Power Plant, located south of the City, contributes heat and thermal pollution.

Extensive urbanization and recreational use of San Clemente's beach over a number of years has resulted in a situation where the principal animals remaining are those which coexist well with man.

\subsection{Cultural Resources}

San Clemente residents and visitors enjoy spectacular scenic resources and unique cultural resources. Coastal Act policies require the protection of scenic coastal areas and the preservation of cultural resources. Scenic resources include coastal bluffs, coastal canyons, and scenic views corridors from publicly-owned properties and along or through public rights-of-way. Historic and cultural resources include sites, districts, structures and distinctive landscapes that convey the City's unique cultural, historical, or architectural 
heritage. Distinctive cultural resources in the Coastal Zone are located in but not limited to the Del Mar/T-Zone, North Beach, Los Molinos and Pier Bowl areas.

Founded by Ole Hanson in 1925, San Clemente was envisioned as a "little Spanish Village by-the-Sea". Development followed a unifying theme which required white stucco buildings with red tile roofs. Many of San Clemente's earlier Spanish style residential, commercial, and public buildings remain, lending a unique character to the community. Those buildings constructed during the Ole Hanson era (1925-1945) that have not been torn down constitute the City's list of historical structures. This totals 210 structures, the majority of which are located within the City's Coastal Zone. Five of the City designated historic structures are considered to be especially significant, with all but one included on the National Register of Historic Places. These are:

\section{- Hotel San Clemente}

Located at 114 Avenida Del Mar in the heart of San Clemente's downtown, this three story building was constructed in 1927 . The building was built by Ole Hanson and designed by Wilmer Hershey. The hotel was listed on the National Register of Historic Places in 1988.

- Oscar Easly Block Building

This building is located at 101 El Camino Real, where El Camino Real intersects with Avenida Del Mar. Best recognized by its Moorish arches, which can be seen from Avenida Del Mar, the building was constructed in 1929. The owner/builder was Oscar Easly and the architect was Virgin Westburg. The building was listed on the National Register of Historic Places in 1983.

- Casa Romantica

The Casa Romantica, 415 Avenida Granada, is located on the coastal bluffs overlooking the Pier Bowl. This structure is the original home of Ole Hanson, the City's founder. Ole Hanson built the Casa Romantica in 1927; the architect was Carl Lindbom. The Casa Romantica is the City's most recent addition to the National Register of Historic Places, listed in 1994.

- Ole Hanson Beach Club

The Ole Hanson Beach Club, located at 105 Avenida Pico, is one of many public buildings given to the town by Ole Hanson. Constructed in 1927, the swimming pool staged the United States Olympic Trails for swimming that same year. The Beach Club is one of the City's primary recreational and entertainment centers. The architect who designed the Beach Club was Virgil Westburg. The Beach Club was listed on the National Register of Historic Places in 1981.

- Casa Pacifica/Western White House

The Casa Pacifica was built in 1927 by H.H. Cotton. The original estate included 110 acres. Approximately one-half of the original estate was used for stables and a one-half 
mile race track. The Cottons raised and trained thoroughbred horses there for over thirty years. The Casa Pacifica property was subdivided in the 1960s; the original ten room home, however, has remained unaltered over the years. President Richard Nixon purchased the Cotton Estate in 1969. During Mr. Nixon's presidency, the Casa Pacifica became known worldwide as the "Western White House." President Nixon sold the Casa Pacifica in 1979 and the property is now owned by Gavin Herbert.

\subsection{Access Routes}

\section{A. Regional Vehicular Circulation}

The principal component of the regional transportation system affecting San Clemente is the San Diego Freeway (I-5). This freeway provides a direct link with the Orange County/Los Angeles metropolitan areas, as well as with San Diego.

Pacific Coast Highway provides a second regional link for beach access is San Clemente. Paradoxically, the Coast Highway is outside the Coastal Zone in San Clemente for much of its length. Known as El Camino Real throughout San Clemente, it defines the major commercial business district of the City. El Camino Real is subject to heavy utilization and congestion on summer weekends and on all holidays.

\section{B. Public Transportation}

There are four bus service lines in the City operated by the Orange County Transportation Authority (OCTA). Public transit services in San Clemente are described in detail below:

Route 1 operates all seven days of the week and connects San Clemente to Long Beach. Within the City of San Clemente, Route 1 runs along El Camino Real. Outside of the City, it runs along Pacific Coast Highway (PCH). This route has timed stops at the intersection of El Camino Real and Santa Margarita and El Camino Real and Avenida Pico within the City. Weekday service frequency is approximately every half hour, with service provided from 4:30 AM to 11:00 PM, and weekend/holiday service frequency is approximately every hour, with service provided from 5:20 AM to 9:30 PM.

Route 91 operates all seven days of the week and connects San Clemente to Laguna Hills. Within the City of San Clemente, Route 91 runs along El Camino Real and Los Molinos. Outside of the City, it runs along Paseo De Valencia, Camino Capistrano, Del Obispo Street and $\mathrm{PCH}$. This route has a timed stop at the intersection of Avenida Pico and Los Molinos within the City. Weekday service frequency is approximately every 35 minutes, with service provided from 4:57 AM to 11:16 PM, and weekend/holiday service frequency is approximately 45 minutes, with service provided from 6:50 AM to 8:24 PM.

Route 191 operates all seven days of the week and connects San Clemente to Mission Viejo via Rancho Viejo Road, Camino Capistrano and El Camino Real. This route has a 
timed stop at the intersection of El Camino Real and Santa Margarita, San Clemente Pier, San Clemente Metrolink Station within the City. Weekday service frequency is approximately every 30 minutes during the AM and PM peak hours, with service provided from 6:00 AM to 7:52 PM, and weekend/holiday service frequency is approximately 60 minutes, with service provided from 6:06 AM to 7:30 PM.

Route 193 operates Monday through Friday and connects San Clemente Metrolink Station to "Pico Plaza" via Camino de Los Mares, Camino Vera Cruz and Avenida Pico. This route has a timed stop at San Clemente Metrolink Station, Wal-Mart San Clemente and Sears Plaza within the City. Weekday service frequency is approximately every 60 minutes, with service provided from 6:00 AM to 7:52 PM and weekend/holiday service frequency is approximately an hour, with service provided from 5:53 AM to 7:14 PM.

\section{Rail Service}

The railroad line between Los Angeles and San Diego runs through San Clemente. A single track, owned and maintained by the OCTA, parallels the coastline. Although the right-ofway is owned by the OCTA, the San Clemente Beach Trail - part of the California Coastal Trail - and protective fencing and improved, signalized pedestrian-grade crossings parallel the railroad tracks and are maintained by the City of San Clemente. Although there is only one railroad track serving the City of San Clemente, it is used by both Amtrak and Metrolink. The two passenger rail services operate separate stations in San Clemente at two different locations. The Amtrak station is located at San Clemente Pier (shared with Metrolink), while the Metrolink station is located at the north beach area. Rail services are described below:

Amtrak provides service for the purpose of recreation in the City of San Clemente. Trains (Pacific Surfliner and California Coastal Services) stop at the San Clemente Pier daily in the spring and summer, from late April to October. During the rest of the year, service is limited to weekends and holidays only. There are four northbound and southbound trains which serve this facility on the weekdays. On weekends, there are two trains (both northbound and southbound) which serve this facility. Regional access to this facility is via Avenida Del Mar and Avenida Madrid, which connect to El Camino Real. Local access to the station is provided through the driveway along Avenida Victoria. Paid parking spaces are currently provided at the station. OCTA bus Route 191/191A serves the station during summer.

Metrolink commuter trains inaugurated service for the City of San Clemente in 1995, providing peak hour commuter transportation to key cities in both Orange and Los Angeles Counties. Currently, two Metrolink lines provide service in the City of San Clemente (at San Clemente Metrolink Station and San Clemente Pier), which are the Orange County Line and Inland Empire - Orange County Line. There are 28 northbound and southbound trains 
which stop at San Clemente Metrolink Station on the weekdays when trains begin accessing the station at 5:04 AM and with service continuing until 7:57 PM. On the weekends, service begins at 9:15 AM and continues until 6:11 PM with 8 trains (both northbound and southbound) accessing the station. Regional access to this station is available from Avenida Pico and El Camino Real. Local access to the station is provided through the driveways along El Camino Real. Paid parking spaces are available at the station. OCTA bus Routes 91 and 191 service the station. Two northbound and two southbound Metrolink trains only stop at San Clemente Pier station on weekends.

\section{Bike and Pedestrian Circulation}

The City of San Clemente promotes safe, convenient and efficient facilities and programs for bicycle and pedestrian travel. There are several bike routes through the city of San Clemente - two run parallel to the coast: one along El Camino Real and one along South Ola Vista. The north/south routes are located on Avenida Pico, Camino De los Mares, and Avenida Vista Hermosa.

The City has a network of trails that run from the beach, up the canyons and along its ridge lines. These trails have been designed to provide a save walking, hiking and riding experience while maintaining San Clemente's coastal environment. The ridge line trails provide spectacular views of the coast in both directions and pristine coastal canyons in adjacent wildlife reserves. San Clemente is an unusual Orange County coastal city in that is bordered on two sides by protected wild lands easily accessible via to San Clemente's citizens the City's trail system.

\section{E. California Coastal Trail}

The City participated and consulted with the National Park Service, the State Department of Parks \& Recreation, the State Coastal Conservancy, and other public and private entities and interested parties in designing, locating, funding, acquiring, and implementing the California Coastal Trail (CCT) segment located within San Clemente's Coastal Zone.

This section of the California Coastal Trail (CCT), known as the "San Clemente Beach Trail", is a popular route used by pedestrians and bicyclists, linking beach access points from North Beach to Calafia State Beach. In the future, the Beach Trail will be part of a continuous trail system traversing the length of the state's coastline, designed and sited to link with contiguous trail links located along many Coastal jurisdictions.

The CCT in San Clemente has achieved these objectives:

a. Provides a continuous walking and hiking trail as close to the ocean as possible;

b. Provides maximum access for a variety of non-motorized uses by utilizing alternative trail segments where feasible;

c. Maximizes connections to existing and proposed local trail systems; 
d. Ensures that all segments of the trail have vertical access connections at reasonable intervals;

e. Maximizes ocean views and scenic coastal vistas;

f. Provides an educational experience where feasible through interpretive facilities.

\subsection{Coastal Access}

Public coastal access is a fundamental goal of the Coastal Act and a key part of San Clemente's charm. But the Coastal Act goes beyond just ensuring physical access. It also emphasizes the importance of recreation and visitor-serving land uses that meet a wide range of incomes and interests.

San Clemente offers many opportunities to use and enjoy the coast, including the many public beaches, ocean front parks, and numerous public access trails that link the community with the Pacific Ocean. San Clemente also provides visitor-serving commercial uses in the Coastal Zone, particularly within the Camino de los Mares, Los Molinos, North Beach, El Camino Real, Del Mar/T-Zone, and Pier Bowl areas. Visitor-serving facilities include hotels, motels, bed and breakfast inns, a youth hostel, time share units, campgrounds, restaurants, public parking lots, specialty retail, and other commercial recreational development.

\section{Public Parking}

A summary identifying the methods of access, types of public facilities, and extent of parking for each of the eighteen specific access points is presented in Table 2.1 
Land Use Plan of the Local Coastal Program, City of San Clemente

Table 2.1: Access Routes and Parking

\begin{tabular}{|c|c|c|c|c|c|c|}
\hline \multirow[t]{2}{*}{ Area Division } & \multirow[t]{2}{*}{ Location/Name } & \multirow{2}{*}{$\begin{array}{l}\text { Type of Public } \\
\text { Access }\end{array}$} & \multirow[t]{2}{*}{ Amenities } & \multicolumn{3}{|c|}{ \# of Parking Spaces } \\
\hline & & & & $\begin{array}{l}\text { Off- } \\
\text { Site }\end{array}$ & $\begin{array}{l}\text { On- } \\
\text { Site }\end{array}$ & Total \\
\hline \multirow[t]{2}{*}{ Estrella/North } & Poche & $\begin{array}{l}\text { Stairs \& tunnel } \\
\text { beneath PCH }\end{array}$ & None & 0 & 10 & 10 \\
\hline & $\begin{array}{l}\text { Capistrano Shores } \\
\text { Mobile Home Park }\end{array}$ & None (Private) & None & 0 & 0 & 0 \\
\hline \multirow[t]{4}{*}{ Pico/Palizada } & North Beach & Footpath & $\begin{array}{l}\text { Picnic table, snack } \\
\text { bar, showers, } \\
\text { restrooms, volleyball } \\
\text { courts, play area \& } \\
\text { fire pits }\end{array}$ & 250 & 100 & 350 \\
\hline & Dije Court & Stairway & None & 0 & 10 & 10 \\
\hline & Ave. W. El Portal & Stairway & None & 0 & 10 & 10 \\
\hline & Mariposa & Asphalt ramp & None & 0 & 15 & 15 \\
\hline \multirow[t]{6}{*}{ Presidio/Central } & Linda Lane City Park & Foot-Path & $\begin{array}{l}\text { Turf picnic area, } \\
\text { restrooms, volleyball } \\
\text { courts, showers }\end{array}$ & 135 & 0 & 135 \\
\hline & Corto Lane & Stairway & $\begin{array}{l}\text { Shares Linda Lane } \\
\text { amenities }\end{array}$ & 0 & 5 & 5 \\
\hline & $\begin{array}{l}\text { San Clemente } \\
\text { Municipal Pier }\end{array}$ & Foot-Path & $\begin{array}{l}\text { Restaurant, tackle, } \\
\text { restrooms, showers, } \\
\text { picnic tables }\end{array}$ & 133 & 102 & 235 \\
\hline & "T" Street & Foot-Path & $\begin{array}{l}\text { Restrooms, showers, } \\
\text { fire pits, picnic } \\
\text { tables, volleyball } \\
\text { courts }\end{array}$ & 0 & 150 & 150 \\
\hline & La Boca del Canon & None (Private) & None & 0 & 0 & 0 \\
\hline & Lost Winds & Foot-Path/Stairs & None & 0 & 10 & 10 \\
\hline \multirow[t]{6}{*}{ Calafia/South } & Riviera & Stairway & None & 0 & 10 & 10 \\
\hline & Montalvo & $\begin{array}{l}\text { Foot- } \\
\text { Path/Stairway }\end{array}$ & None & 0 & 0 & 0 \\
\hline & Calafia-S.C. State Beach & Foot-Path & $\begin{array}{l}\text { Restrooms, snack } \\
\text { bar, fire pits, } \\
\text { showers }\end{array}$ & 210 & 0 & 210 \\
\hline & $\begin{array}{l}\text { San Clemente State } \\
\text { Beach }\end{array}$ & Footpath/Tunnel & $\begin{array}{l}\text { Restrooms, showers, } \\
\text { picnic tables, BBQs }\end{array}$ & 200 & 0 & 200 \\
\hline & Ave. de as Palmeras & None (Private) & None & 0 & 0 & 0 \\
\hline & Calle Ariana & None (Private) & None & 0 & 0 & 0 \\
\hline Totals & & & & 928 & 422 & 1,350 \\
\hline
\end{tabular}




\subsection{Urban Setting}

The Coastal Zone is approximately 2,058 acres in area, of which approximately 80 percent is developed. Aside from the now vacant (in 2013) Marblehead Coastal property, the State Park, several city parks, beaches, bluffs and coastal canyons, the Coastal Zone consists mostly of urbanized areas with residential, commercial and or industrial development. The last significant parcel of undeveloped land in San Clemente and in the Coastal Zone is the 253 acre Marblehead Coastal site, located southwest of the Interstate 5 Freeway (1-5) and bounded by $1-5$ and Marblehead Inland across the freeway to the northeast, the Shorecliffs and Colony Cove residential areas to the northwest, the Avenida Pico corridor and North Beach areas to the southeast, and El Camino Real (Pacific Coast Highway) to the southwest. Marblehead Coastal consists of approximately 248 acres of land and has several significant features, including coastal canyons and bluffs, which are visible from many areas of the community. Proposed uses which are approved for development under the Marblehead Coastal Specific Plan include:

a. Regional commercial center with approximately 640,000 square feet of retail uses;

b. Coastal visitor-serving commercial uses at the southerly corner of the the site, to include visitor-serving services and facilities, located adjacent to ocean view parks and the entertainment-oriented North Beach; and

c. Two residential neighbhorhoods consisting of 313 dwellings, parks and trails.

\subsection{Recreational Resources}

Ole Hanson realized recreational spaces and opportunities are an important aspect in providing a high quality of life for the citizens of San Clemente. Perhaps the greatest recreational asset of San Clemente is its coastal setting, enjoying a sunny Mediterranean climate with mild winters and warm summers. The vast open space areas along San Clemente's eastern, southern, and western borders (Camp Pendleton, Cleveland National Forest, and the Pacific Ocean) have helped to maintain its small town character and enhanced its recreational opportunities. The beaches, parks, and community focal areas within San Clemente's Coastal Zone provide a wide range of recreational opportunities. This section describes San Clemente's most valuable recreational resources. Figure 2-25 identifies the location of recreational amenities in the Coastal Zone.

\section{A. Municipal Pier}

With the development of San Clemente, Ole Hanson provided a-number of recreational facilities. Two of these facilities within the Coastal Zone, the Municipal Pier and the Ole Hanson Beach Club remain in use today. The quarter mile long Municipal Pier was built as a gift to the community in 1928. The Municipal Pier has been destroyed by large surf and rebuilt several times, most recently in 1983 . The primary recreational use of the Pier is for fishing and for quiet strolls to enjoy the beautiful setting and sunset. At the base of 
the pier is the Fisherman's Restaurant and Bar.

\section{B. Ole Hanson Beach Club}

The Ole Hanson Beach Club and swimming pool was also built in 1928, and has since been a focal area for recreational activities for San Clemente. The Beach Club is situated at North Beach on Avenida Pico and Boca de la Playa. The Beach Club has two meeting rooms, two outdoor terraces, showers, bathrooms, kitchen facilities, a six lane 25-yard pool and an instructional pool. The Beach Club is used for a variety of uses including: open lap swimming, recreational swimming, swim lessons, scuba, water aerobics, recreational classes, City meetings, and for weddings and receptions.

\section{Community Center/Senior Center And Public Library}

The San Clemente Community Center, Senior Center, and Public Library are situated in the heart of downtown San Clemente at Avenida Del Mar and North Calle Seville. The Community Center contains an auditorium, kitchen, art gallery, meeting rooms, and the offices of the Beaches, Parks, and Recreation Department. The surrounding grounds offer shuffleboard courts and passive open space area. The Library Complex, in addition to housing the County Library, include two multi purpose rooms, an arts and crafts room, and a kitchen area. The Senior Center is utilized for a wide variety of functions such as dining, films, arts and crafts, meetings, and a variety of other functions.

\section{Parks}

There are a total of eight City operated parks located within the Coastal Zone:

\section{- Community Center Park}

The Community Center Park is located at the northeast corner of Avenida Del Mar and North Calle Seville. The park has an area of 1.75 acres and includes meeting rooms, outdoor shuffleboard, and a grass play area. The library and Senior Center are immediately adjacent to the Community Center.

\section{- San Gorgonio Park}

This 23 acre community park is located south of the San Diego Freeway (I-5) between Via San Gorgonio, Avenida Vaquero and Calle Vista Torito. Facilities at this park include two Little League diamonds, a football field, a soccer field, a basketball court, picnic facilities, restrooms, and 130 parking spaces.

- Bonito Canyon Bicentennial Park

Bonito Canyon is an 11 acre community park located north of El Camino Real at Calle 
Valle. This park facility includes a picnic area, Little League diamond, children's play area, restrooms, and a grass play area. Bonito Canyon is also the location of the Boys and Girls Club facility, which includes two indoor gyms, game room, arts and crafts and meeting room. There is parking for 60 vehicles.

\section{- Max Berg Plaza Park}

This 3.62 acre neighborhood park is located in the block surrounded by El Prado, Calle Puente, Avenida Aragon, and Avenida Del Poniente. The park contains a children's play area, rose garden, fountain, restrooms, and grass play area.

\section{- $\quad$ Linda Lane Park}

Linda Lane Park is a four acre site located within the Pier Bowl and Linda Lane, adjacent to the beach. Recreational amenities include coastal access, swings and creative play equipment, picnic tables, benches, grass play area and metered parking.

\section{- $\quad$ Parque Del Mar}

Parque Del Mar is located in the heart of the Pier Bowl Area. This park primarily serves as an extension of the pier and beach facilities. The Parque Del Mar is a linear park that extends from the Beachcomber Hotel to the base of the bluff below the Casa Romantics. Parque Del Mar includes the main entrance to the Municipal Pier, the Amtrak Station, picnic tables, and passive open space.

\section{- Leslie Park}

Situated between Calle de 10 s Alamos and the Coastal Bluff, Leslie Park is a 4,500 square foot pocket park. The park is divided into two viewing levels, which are connected by a walkway and set of stairs built in 1980 . There is no beach access from this park. Leslie Park provides panoramic views up and down the coast from the top of a steep cliff.

\section{- $\quad$ Calafia Beach Park}

Calafia Beach Park is located at the end of Avenida Calafia at the mouth of a coastal canyon. The lower portion of this park includes coastal access, bathrooms, showers, and a beach concession facility. A portion of this park is located on the coastal bluff overlooking the beach and parking area. This area includes passive open space with benches and scenic vistas. 


\section{E. Schools}

Three schools are located within the City's Coastal Zone and provide active recreation areas:

\section{- $\quad$ Concordia Elementary School}

This school is located west of Avenida Presidio and south of the San Clemente State Park boundary and contains a baseball diamond and children's play area.

- Las Palmas Elementary School

Located on Calle Puente between Del Poniente and Avenida Aragon, this school has a baseball diamond, soccer field, and children's play area.

- Shorecliffs Middle School

Located at 240 Via Socorro, the school includes basketball and volleyball courts, track and a sports field.

\section{F. Beaches}

Located between the Dana Point Headlands and San Mateo/Cotton's Point is the Capistrano Bight. Within the Capistrano Bight is a southwestern facing stretch of coastline with pristine sandy beaches, four-and-one-half miles of which make up the San Clemente coastline. San Clemente beaches are popular for surfing, body boarding, sun bathing, volleyball, fishing, and other ocean related activities. The beaches within San Clemente are divided into State, City, and private beaches.

\section{- $\quad$ San Clemente State Beach}

San Clemente State Beach includes 6,000 feet of shoreline, and 110 acres of campground area at the southern end of San Clemente's Coastal Zone. The campground facilities accommodate approximately 180,000 visitors a year although the number of campers will fluctuate from year to year based on weather conditions. The San Clemente State Beach campgrounds are one of the most heavily utilized facilities in the State Park system. There are currently 157 camping spaces: 85 family camp sites; 72 with disposal hookups for campers. In addition there is one group campsite that accommodates up to fifty people. 
The San Clemente City Beach includes two miles, or approximately twenty acres, of coastline. Annually, City beaches receive approximately two million visitors. The number of visitors in any one year is greatly dependent on the summertime weather. The most heavily used City beaches are the Pier Bowl, North Beach, and "T" Street. The Pier Bowl, with its concentration of year around activities, is the City's most popular beach. Some of the facilities on the beach include: the Municipal Pier, volleyball courts, fire pits, picnic areas, beach concession stands, restrooms, and showers.

\section{- $\quad$ Private Beaches}

Two sections of the City's coastline at the City's extreme northern and southern borders are privately owned, restricting the access and use of these beaches. The northern section of private beach begins at the City's northern border and stretches south approximately one mile. This section of beach is owned by Shorecliffs Homeowners Association, Palm Beach Mobile Home Court, the Capistrano Shores Mobile Home Park, and several private owners. Near the City's southern border is approximately one half mile of beach owned by the Cypress Cove and Cypress Shores Homeowners Associations.

\section{G. Surfing Areas}

San Clemente is a well known surfing area and is the home of many of the world's past, present and future surfing professionals. The surf areas located within or near the City's Coastal Zone are valuable recreational resources that are enjoyed year round. There are a total of eight established surfing areas within the City's boundaries. Perhaps the most well known surfing beaches in the area, are Trestles and San Onofre, located just south of the San Clemente city limits. From north to south the surfing beaches within San Clemente include:

- Pochè - Pochè includes both a reef break and beach break and is located in the northern portion of the City's Coastal Zone.

- 204-Considered both a rock reef break and a beach break; 204 is located just south of North Beach.

- The Pier - The Pier is a beach break where wave shape is enhanced by the buildup of sand next to the pier. The Pier break is located on the north side of the Municipal Pier. Surfing on the south side of the Pier is prohibited.

- T-Street - T-Street is a reef break that is located in front of the T-Street overpass. During the 
summer, surfing is not allowed due to its popularity with body boarders and bodysurfers. Surfing is allowed at the beach break just south of T-Street (named "Beach House").

- Lost Winds - Lost Winds is a beach break that is located in front of the Lost Winds access point.

- Riviera - Riviera is a beach break located adjacent to the Riviera Beach storm drain and access point.

- State Park - State Park is a beach break that is located south of the Calafia Beach access point.

- Cotton's Point - Cotton's Point is located at the very southern edge of the City limits and is an outstanding left point break. The closest public access is the Trestles access.

\section{H. Community Events}

San Clemente holds a variety of community events during the year. Some of theses events include:

- The Ocean Festival - Billed as "The Greatest Show on Surf' the Ocean Festival features a variety of ocean related events. Held during the month of July, the Ocean Festival continues to increase in attendance and the number of events since its early beginning in 1977 as a lifeguard competition. In addition to the traditional lifeguard competition, ocean events also include surfing contests and legends presentation, sand castle building contest, ocean related arts and displays, presentations on the history of surfing, music, biathlon competition, swimming contest, junior king neptune and little mermaid competitions, and more.

- The Fiesta - The Fiesta, held during the month of August, is an annual block party event on Avenida Del Mar. During the Fiesta, downtown streets are closed to vehicles and Avenida Del Mar is transformed into a giant stage where the music plays all day long. This carnival atmosphere includes three stages where performers play music that range from country to rock-and-roll. There are also rides and games for children, food, drinks and other types of street entertainment.

- Fourth of July Fireworks - The Fourth of July Fireworks show is among the most popular of San Clemente's community events. The fireworks show first began at the end of the Municipal Pier in the 1950's and has continued every year since. The Fourth of July 
weekend is the most popular weekend of the year and attracts thousands of people to the City's beaches. 


\section{CHAPTER 3: GOALS AND POLICIES}

\subsection{Overview of Coastal Policies}

This portion of the Land Use Plan establishes the goals and policies that will determine the manner in which growth, development and preservation occur in the City's Coastal Zone. The policies in Chapter 3 of the Coastal Act (Public Resources Code Sections 30200 through 30263) are the guiding policies of the Land Use Plan. This Element is consistent with the policies stated in the other "elements", or chapters, of San Clemente's General Plan. The policies stated in this chapter are directly related to the desired goals and the identified issues within the community, and are intended to achieve San Clemente's vision for the future.

In general, the Coastal Policies address the following:

1) Provide for the appropriate mix and type of land uses which will attract visitors to San Clemente and serve the existing and future needs of the community;

2) Provide for the revitalization, adaptive reuse, and upgrade of deteriorated neighborhoods and districts;

3) Require new development within the Coastal Zone to be consistent with the policies of the California Coastal Act;

4) Provide and maintain a comprehensive and safe beach access network;

5) Provide and maintain recreational areas, recreational activities, and visitor serving facilities;

6) Protect, where appropriate, public view corridors and historic resources;

7) Provide and maintain a safe and healthy beach for the enjoyable utilization of the marine environments;

8) Protect and preserve, where possible, significant wildlife habitats which exist in the Coastal Zone;

9) Maintain San Clemente as a unique and distinctive place in southern Orange County and the greater region

\subsection{Coastal Land Use Goals and Policies}

The Land Use Plan utilizes the same land use designations found in the Land Use Element of the City's General Plan. This section defines the general land use policies of the Coastal Zone pertaining to density, height, design and development standards. Land use policies in the Land Use Plan provide for the development while preserving unique natural features of the coastal environment. This section describes the policy intent, goals and policies for all land use categories within the Coastal Zone (see the Coastal Land Use Map, Figure 3.1 and Table 3.1).

\section{A. Residential Land Use Policies \\ Policy Intent}


Plan policy provides for the preservation of the residential neighborhoods in the Coastal Zone. With the exception of Marblehead Coastal's 313 proposed dwellings, residential growth is limited to infill development. Only the area located between Avenida Pico and Trafalgar Lane would realize any significant changes in density as existing medium and high-density residential properties gradually build out to their maximum allowed densities.

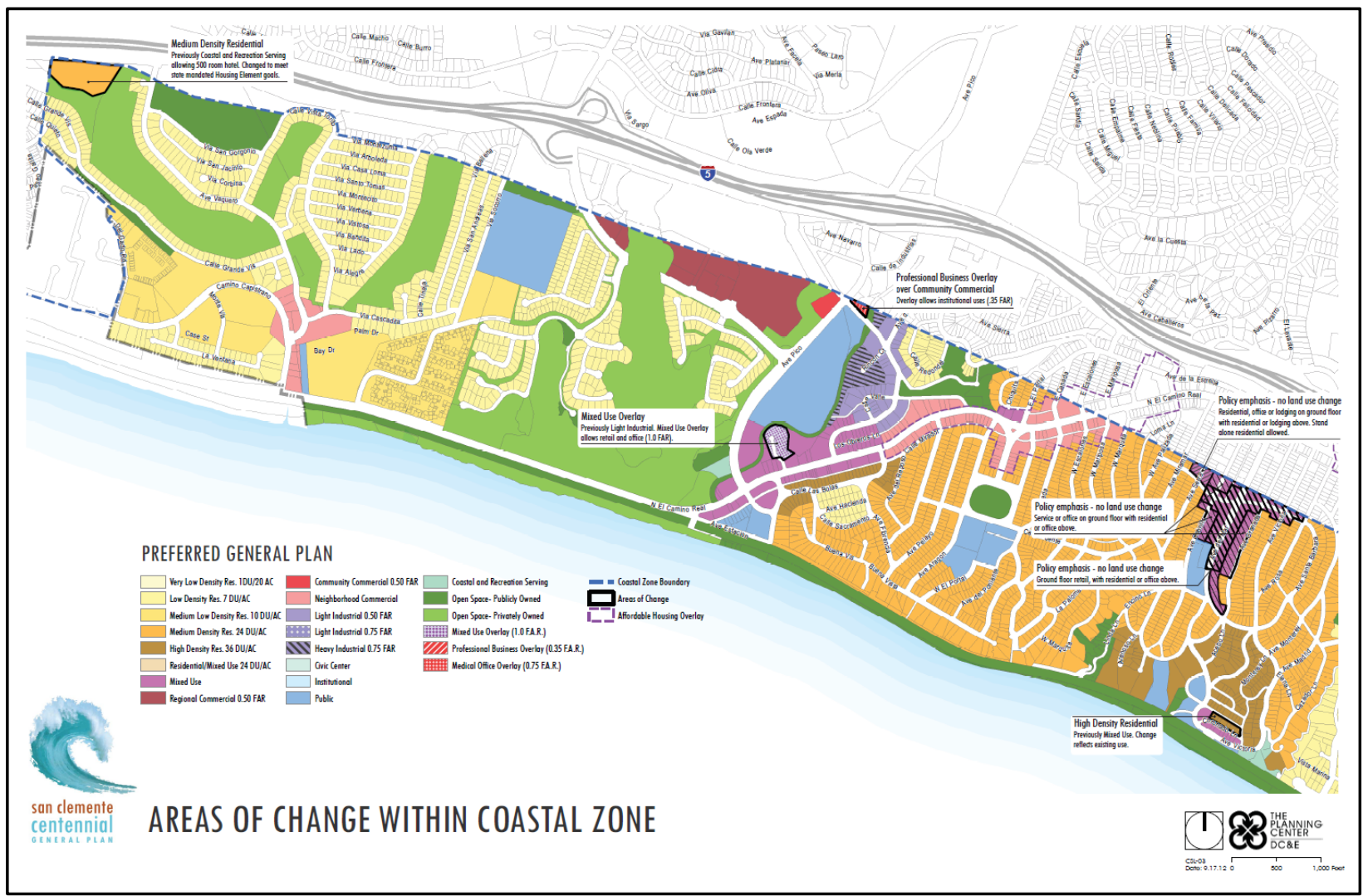

Figure 3.1: Coastal Land Use

\section{Goal}

1. Retain and enhance established residential neighborhoods to meet the diverse economic and physical needs of the existing and future residents of the City.

\section{Policies}

1.1 Accommodate the development of a variety of housing types, styles, tenure and densities that are accessible to and meet preferences for different neighborhood types (e.g., mixed use pedestrian environments and traditional suburban neighborhoods), physical abilities and income levels, pursuant to the Land Use Plan and Housing Element. 
1.2 Require residential developments to be designed to promote safe and convenient access to nearby commercial centers, community facilities, parks, open space, transit facilities, bikeways, trails and other amenities, as applicable.

1.3 Maintain elements of residential streets that unify and enhance the character of the neighborhood, including parkways, street trees, and compatible setbacks

Single Family Residential

1.4 Require that single-family houses and sites be designed to convey a high level of architectural and landscape quality in accordance with the Urban Design Element and Zoning Code and in consideration of the following:

1) Varied and distinct building elevations, facades, and masses (avoiding undifferentiated "box-like" structures)

2) Building scale and massing compatible with existing development;

3) Use of extensive site landscaping to complement the architectural design of the structure

4) Minimization of amount and width of the paving of front yards for driveway and garage access

5) Location and design of garages so that they do not dominate the street frontage

1.5 Accommodate the development of single family residential units at a maximum density of 4.5 units per acre or 7.0 units per gross acre as stipulated in Table 3-1 in areas designated as "RL."

\section{Multi-family Residential}

1.6 Require that multi-family residential projects be designed to convey a high level of quality and distinctive neighborhood character in accordance with the Urban Design Element and Zoning Code. New multi-family housing development projects shall:

1) Use building materials, colors, and forms which complement the neighborhood, while allowing flexibility for distinguished design solutions

2) Design all building elevations to convey the visual character of individual units rather than a single, continuous building mass and volume

3) Visually hide or buffer subterranean parking garages

4) Use a well-defined roofline

5) Include separate, well-defined entries to convey the visual character of individual identity of each residential unit. Entries may be developed onto exterior facades, interior courtyards, and/or common areas 
6) Locate and design parking areas and garages to be architecturally integrated with and complementary to the main structure

7) Use adequate site landscaping

8) Include setbacks, consistent with the surrounding neighborhood, along the street frontage containing landscaping. Building entries shall be connected to public sidewalks to encourage safe and convenient pedestrian access

9) Reduce the length and width driveway paving in relation to landscaping

10) Provide on-site open space amenities that are accessible and of sufficient size to be usable by tenants, in common areas and/or with individual units pursuant to the Zoning Code

1.7 Accommodate the development of single and multi-family residential units at maximum densities as stipulated in Table 3-1:

1) "RVL": maximum density of one unit per 20 gross acres or legal parcel of record, whichever is smaller

2) "RL": maximum density of 4.5 units per gross acre and 7.0 units per net acre.

3) "RML": maximum density of 7.0 units per gross acre or 10.0 units per net acre

4) "RM": maximum density of 15.0 units per gross acre or 24.0 units per net acre

5) " $\mathrm{RH}^{\prime}$ : maximum density of 24.0 units per gross acre or 36 units per net acre

1.8 Require that multi family residential projects be designed to convey a high level of quality and distinctive neighborhood character in accordance with the Urban Design Element.

Residential Infill

1.9 Require that new residential development in existing residential neighborhoods or along commercial corridors be compatible with existing structures, including the:

1) Mitigation of noise, traffic (automobile and truck), and lighting impacts of abutting commercial uses, where applicable

2) Use of complimentary building materials, colors, and forms, while allowing flexibility for distinguished design solutions

\section{B. Commercial and Mixed-Use Land Use Policies}

\section{Policy Intent}

Plan policy provides for the attraction and accommodation of an expanded range of retail, office, restaurant, entertainment, hotel and other commercial uses intended to support the needs of coastal visitors and the daily needs of residents. Plan policy also provides for the development of mixed commercial and residential areas. Mixing such uses is intended to reduce vehicular trips and associated air pollution, housing opportunities in proximity to jobs 
and services, and along with the City's newly adopted "Complete Streets" policies, establish active, pedestrian- and bicycle-oriented districts which enhance the quality of life and the vitality of the City's coastal activity areas. The plan concentrates mixed-use projects in the three coastal activity centers, Downtown, the Pier Bowl, and North Beach.

\section{Goal}

2. Provide for the development of resident and visitor-serving, recreation oriented commercial and supporting uses which are in harmony with, yet capitalize on the ocean and beachfront and hillsides and canyons and are attractive and compatible with adjacent residential neighborhoods and commercial districts.

\section{Policies}

2.1 Accommodate the continuation of existing and development of a mix of new neighborhood, visitor-serving commercial centers in areas designated respectively as "NC" and "CRC" in accordance with the density and height standards stipulated in Table 3-1.

2.2 Accommodate the development of a mix of residential and commercial uses in areas designated as "MU" in accordance with the density and height standards stipulated in Table 3-1.

2.3 Accommodate the development of commercial uses in overlay areas designated as "-p".

2.4 Require that new development protect community character by providing architecture, landscaping and urban design in a manner that achieves a high level of quality, distinctive character and compatibility with existing uses and development, and that respects the architectural character and scale of adjacent buildings, in accordance with the Land Use Element and the Urban Design Element.

2.5 Require distinctive entry and informational signage, street trees, street furniture, pedestrian-scaled lighting, and other improvements to uniquely identify individual commercial districts.

2.6 Designate lands for the development of coastal related commercial, recreational, lodging, and supporting uses on the Coastal Land Use Plan Map and establish standards to ensure their compatibility with adjacent residential neighborhoods and commercial districts. 
2.7 Require that commercial projects abutting residential neighborhoods be designed and operated to protect residents from the effects of noise, light, odors, traffic, parking and other operational impacts.

2.8 Require the maintenance of commercial areas to ensure they reflect our expectations for a quality environment and remain competitive with commercial facilities located outside of the City.

2.9 Permit a range of horizontally and vertically mixed uses appropriate to key areas in the City.

2.10 Apply flexible development standards to respond to changing market demands as long as they contribute to the vision and desired community character and are consistent with Coastal Act policies.

Pedestrian, Bicycle and Transit Access

2.11 Require commercial projects to be designed to promote convenient access to and from nearby neighborhoods, transit facilities, bikeways, and other amenities.

Ground Floor Retail

2.12 In pedestrian-oriented environments, such as the Coastal visitor-serving Downtown Core, we require retail uses to be located on the ground floor and near the public sidewalk to provide convenience and good visibility for shoppers.

2.13 Whenever possible, we require off-street parking to be screened and located on the side or at the rear of buildings.

Upper Floors

2.14 Where buildings over two stories are allowed, we require building facades above the second floor to be set back from lower, street-facing facades to minimize building height and bulk, pursuant to the Zoning Ordinance, Design Guidelines, and applicable Specific Plans.

\section{Stand Alone Residential}

2.15 Where new, stand alone residential developments are allowed within areas designated for mixed use, we require development to be compatible with adjacent commercial and mixed uses and with adjacent neighborhoods. Such developments shall:

1) Buffer the residential use from abutting commercial uses. 
2) Adequately mitigate the noise, traffic, parking (automobile and truck), and lighting impacts of abutting commercial uses.

3) Locate and design dwellings to provide adequate security and privacy for residents; and prevent adverse impacts on the integrity and continuity of other commercial uses by considering the long term needs of commercial and residential uses, such as commercial loading, solid waste and recycling storage, private open space, landscape buffers, noise and odors.

\section{Industrial Land Use Policies}

\section{Policy Intent}

Lands designated for the accommodation of industrial, business park, and similar uses provide employment opportunities for the City's residents. The Plan provides for the retention of light and heavy industrial uses and the development of new industrial uses and related commercial uses in the Los Molinos area while allowing for the revitalization of the area into a cohesive business park.

\section{Goal}

3. Diverse employment opportunities located in areas that provide strategic advantages for employer to locate in San Clemente, while minimizing impacts on surrounding neighborhoods.

\section{Policies}

3.1 Accommodate the continuation of existing and the development of new light manufacturing, research and development, professional offices, supporting retail commercial (including, but not limited to, sales areas for manufacturers and photocopy stores), restaurants, financial institutions, and similar uses in areas designed as "I 2".

3.2 Accommodate the development of heavy manufacturing and related industrial uses in areas designated as I 3, according to the density and height standards stipulated in Table 3-1.

3.3 Permit development according to the following standards for intensity and height:

1) "I 2": a maximum FAR of 0.50 and height of two (2) stories.

2) "I 3": a maximum FAR of 0.75 and height of two (2) stories, which may be increased to accommodate unique physical site operations. 
3.4 Require that projects be designed and developed to achieve a high level of quality, distinctive character, and compatibility with existing uses and development in accordance with the policies contained in the Land Use Element and the Urban Design Element.

\section{Automobile Related}

3.5 Permit the development of fueling stations and support facilities in commercial and business park districts, provided they are:

1) Designed to convey a high quality architectural and landscape character, consistent with the overall character and image of the City, as specified in the Urban Design Element

2) Located at a limited number of key activity intersections, as designated in the Specific Plans for the Ranches.

3.6 Permit the continuation of gasoline stations and supporting service facilities located along major streets and highways in 2012 and require that expansions or modifications of such facilities be designed to convey a high quality architectural and landscape character, consistent with the overall character and image of the City as specified in the Urban Design Element.

3.7 Permit the development of auto-related service and repair uses (e.g., tire shops, lube and tune, and other similar uses) in commercial and business park districts and designated sites within specific plans provided that the facilities for such uses are designed to convey a high quality architectural and landscape character, consistent with the overall character and image of the City as specified in the Urban Design Element.

3.8 Prohibit new and expanded automobile related uses along El Camino Real and in other commercial and mixed-use areas of the City designated to promote pedestrian activity.

3.9 Consider all auto service and repair uses located along El Camino Real, existing as of date of adoption of this General Plan, to be legal, conforming land uses

\section{Public and Institutional Land Use Policies}

\section{Policy Intent}

The Plan designates lands for public and institutional uses such as governmental administrative, recreational, cultural, and educational to support the existing and future population and development of the City. 


\section{Goal}

4. Provide for the continuation of existing and the development of new public cultural, religious, and institutional uses and facilities which meet the needs of the residents.

\section{Policies}

4.1 Allow the continuation of public recreational, cultural (libraries, museums, etc.), educational, institutional (governmental, police, fire, etc.), and health and social service uses at their locations as of the date of adoption of this General Plan. We also allow the development of new Public and Institutional uses in areas designated as Institutional and in any other land use zone where they complement and are compatible with adjacent land uses

4.2 Allow new private and non-profit recreation, cultural, educational, institutional, and health and social service uses in areas designated for commercial or business park uses, and other uses as are identified on the Land Use Plan, provided they are compatible with adjacent uses

4.3 Allow for the continuation of existing and development of new religious facilities in any land use zone where they are compatible with adjacent uses.

4.4 Allow for the continuation of existing and development of new child and adult day-care facilities in any land use zone where they are compatible with adjacent uses.

4.5 Establish standards for City-owned facilities and coordinate with other public agencies to ensure that public buildings and sites are designed to be compatible in scale, mass, character, and architecture with existing buildings and to ensure they follow design standards in this General Plan for the district or neighborhood in which they are located, including the use of landscaped setbacks, walls, and other appropriate elements to mitigate operational and visual impacts on adjacent land uses.

4.6 Allow for the continuation of existing public recreational, cultural (libraries, museums, etc.), educational, institutional (governmental, police, fire, etc.), and health uses at their present locations and development of new uses in areas designated as "P" on the Coastal Land Use Map and in other land use zones where they complement and are compatible adjacent land uses and development is contingent on City discretionary review and approval.

\section{E. Open Space Land Use Policies}

\section{Policy Intent}


Lands are designated for parks, beaches, passive open space, and recreational trails to provide recreational opportunities and maintain the scenic beauty of the community. Plan policy includes the continuation of existing parks, beaches, and trails; preservation of open space which is publicly owned, encumbered by easements, or maintained by homeowners associations; dedication of new parklands and open space through the development review process; preservation of coastal canyons and significant environmental habitats, and the construction of new pedestrian and bike trails in the City.

\section{Goal}

5. Preserve open spaces for the City's residents which provide visual relief, amenities and recreational opportunities, protect environmental resources, protect the population from environmental resources, protect the population from environmental hazards, and are in balance with new development

\section{Policies}

5.1 Designate lands for the provision of recreational open spaces on the Coastal Land Use Plan Map which are sufficient to meet the needs of existing and future residents.

5.2 Designate lands for the provision of passive and visual open space on the Coastal Land Use Plan Map, which provide a balance to the urban and suburban development of the City.

5.3 Designate lands for the protection of significant environmental resources and protection of life and property from environmental hazards on the Coastal Land Use Plan Map.

5.4 Provide for the development of additional open spaces for recreational purposes in accordance with the Beaches, Parks and Recreation Element and Beaches, Parks and Recreation Master Plan.

5.5 We acquire and maintain the most current information available regarding the status and location of sensitive biological elements (species and natural communities) and use this information to guide decisions that could affect biological resources.

5.6 In natural areas that are undeveloped or essentially so, we require applicants for proposed projects to:

1) avoid significant impacts, including retention of sufficient natural space where appropriate;

2) retain watercourses, riparian habitat, and wetlands in their natural condition; 
3) maintain habitat linkages (wildlife corridors) between adjacent open spaces, water sources and other habitat areas and incorporated these into transportation projects and other development projects to maintain habitat connectivity;

4) incorporate visually open fences, or vegetative cover (Clarify what "visually open fences" and "vegetative cover" mean) to preserve views, ensure continued access and to buffer habitat areas, open space linkages or wildlife corridors from development, as appropriate;

5) locate and design roads such that conflicts with biological resources, habitat areas, linkages or corridors are minimized; and

6) utilize open space or conservation easements when necessary in order to protect sensitive species or their habitats.

5.7 We prohibit development and grading which alters the biological integrity of Environmentally Sensitive Habitat Areas, or "ESHAs", including riparian and other wildlife corridors, unless no feasible project alternative exists which reduces environmental impacts to less than significant levels, or it is replaced with habitat of equivalent value, as acceptable to the City Council.

Where no environmentally feasible alternative exists, development within Riparian Corridors shall avoid removal of native vegetation; prevent erosion, sedimentation and runoff; provide for sufficient passage of native and anadromous fish; prevent wastewater discharges and entrapment; prevent groundwater depletion or substantial interference with surface and subsurface flows; and protect and reestablish natural vegetation buffers.

5.8 We preserve the habitat of threatened and endangered species in place as the preferred habitat conservation strategy.

5.9 We encourage activities which improve the natural biological value, integrity and corridor function of the coastal canyons and bluff areas through vegetation restoration of California native landscaping, control of non-native species, and landscape buffering of urban uses and development.

5.10 We support and will follow the U.S. Fish and Wildlife Services Orange County Southern Subregion Habitat Conservation Plan (HCP) and Habitat Management Program.

5.11 To change a property's Open Space designation to another designation allowing uses other than Open Space uses shall require an affirmative vote of registered voters in San Clemente. 


\section{F. Special Districts \\ Policy Intent}

Plan policy provides for a hierarchy of special districts which, due to their unique character and land uses, are considered in further detail to address their functional role and physical form. The special districts include: Downtown San Clemente, Pier Bowl, North Beach and Marblehead Coastal. The policy intent for each of these districts is as follows:

\section{Downtown}

Downtown San Clemente, which functions as the symbolic "core" of the City, will continue to emphasize its pedestrian and "village" character. Coastal visitor-serving uses, with residential units on the upper stories, are encouraged. Architecture is required to be Spanish Colonial Revival, and site design will emphasize building along street frontages that incorporate courtyards, arcades, streetscape, and similar designs to encourage pedestrian activity.

\section{Pier Bowl}

The Pier Bowl is a high activity, coastal visitor-serving and pedestrian-oriented activity center serving the community and tourists and capitalizes on its exceptional ocean views and location abutting the beach and San Clemente Pier. Ole Hanson's former home (now the Casa Romantica Cultural Center and Gardens) is located here, along with many other historic properties. The Pier Bowl is another key area of the City with a rich heritage.

The Pier Bowl is defined by its exceptional beach experience, rich history, nearby amenities, and its own Amtrak/Metrolink station. It is an ocean-side recreation area with a mix of housing types, lodging beach- and community-serving retail uses, small-scale supporting services, and strong connections to other the Del Mar/T-Zone and North Beach areas. It also contains one of the City's most recognizable landmarks - the San Clemente Municipal Pier-a destination in its own right, offering dining, sightseeing, fishing and other recreation opportunities.

In addition to the General Plan Land Use Plan, development in the area is also guided by the Pier Bowl Specific Plan.

\section{North Beach/North El Camino Real}

The North Beach/North El Camino Real Focus Area is a unique, community- and coastal visitorserving entertainment hub and recreation area that serves as a gateway along the historic El Camino Real/Pacific Coast Highway from beach cities to the north. The area's ongoing revitalization is based on the community's desire to preserve and enhance its key assets: views of the ocean, access to the beach, a rich inventory of historic assets, access to passive and 
active recreation and numerous commercial retail and service opportunities for locals and visitors alike.

With access to the Metrolink rail station, the Beach Trail, numerous bikeways and pedestrian paths, and the historic El Camino Real corridor that connects many of the City's activity areas, the NB/NECR area is a key coastal visitor-serving, recreation and multimodal transportation hub for the community. There is a balance between automobile, bicycle and pedestrian orientation, and the Area is well connected to adjacent neighborhoods.

\section{Goal}

6. Develop special mixed-use districts for these key coastal activity areas within the Coastal Zone. The district will expand upon the general land use policies and standards previously identified in order to accommodate these areas' unique needs.

\section{Policies}

Pier Bowl

6.1 Preserve public view corridors consistent with the Urban Design Element [note: these are the same corridors identified in the Pier Bowl Specific Plan]. Ocean views are among the most valued assets in the Pier Bowl area. New development should take advantage of, and not obstruct these important view corridors.

6.2 Accommodate development that is compatible with coastal-oriented and communityserving commercial (including overnight accommodations), mixed residential and commercial, and public recreational uses whose function or scale are compatible with the recreational character of the area.

6.3 To address parking constraints during peak season and peak hour demand, we prioritize parking strategies that reexamine improved efficiencies at existing parking lots, encourage shared parking, explore greater use of and access to remote parking facilities, and minimize impacts to existing view corridors.

6.4 Provide strong connections to the Del Mar/T-Zone area with visual cues such as signage, landscaping and lighting and work with property owners and businesses to provide transit options for visitors seeking to visit both the Pier Bowl and Del Mar/T-Zone destinations.

6.5 Provide clear wayfinding signage at key locations throughout the area (e.g., train station, Pier Bowl parking lot, Casa Romantica, etc.) to direct visitors to local amenities. 
6.6 Preserve Pier Bowl historic resources and historic character through enforcement of the policies of the Historical Preservation and Urban Design Elements and enforcement of our Zoning Code, including the Spanish Colonial Revival Architectural Overlay.

6.7 Leverage Del Mar/T-Zone and Pier Bowl economic development efforts and special events to enhance regional appeal and encourage visitors to visit both destinations. The City will support efforts to develop tools that aid in the area's revitalization.

6.8 Provide a distinctive visual and physical environment for the Pier Bowl's public streetscape in accordance with the Urban Design Element, including the use of consistent street trees, landscape (planters), street furniture (benches, trash receptacles, news racks, etc.), street and crosswalk paving, pedestrian-scaled lighting, public and entry signage, and other appropriate elements.

6.9 Accommodate a mixture of residential, recreational and commercial land uses within the Pier Bowl by establishing land use as "MU 4-1-p-A," "MU 4-2-p-A," "MU4-3-p-A," "PA," "RM-A," "OS1," "RH-A" and "CRCI-PA" (see Table 3-1).

6.10 Preserve the historic Casa Romantica to ensure it continues to function as a cultural center and gardens, and ensure development is limited to structures that support the cultural center and do not change the facility's scale, architectural character and historic integrity, following the Secretary of the Interior's Standards for the Treatment of Historic Properties.

\section{North Beach/North El Camino Real}

6.11 Preserve North Beach historic resources, through measures such as considering the establishment of a historic district, ensuring new development is consistent with the Historic Preservation Element, providing historic preservation incentives, and enforcing the protective measures of the Zoning Ordinance. We encourage the rehabilitation and adaptive reuse of the historic Miramar Theatre as a movie theater, performing arts center or other high quality cultural use.

6.12 Maintain attractive gateways and informational signage signifying arrival to the North Beach/North El Camino Real area at the following locations along North El Camino Real: 1) the northern entrance to North Beach, 2) the historic entryways to Max Berg Plaza Park at El Portal, and 3) the southern entryway to the area at Avenida Palizada.

6.13 Preserve and enhance safe, convenient pedestrian and bicycle linkages to the shoreline for community and visitor access. 
6.14 Preserve the General Plan-designated view corridor from Avenida Pico through North Beach and encourage new development along El Camino Real to take advantage of ocean vistas.

6.15 Require that site, building and landscape development be of high quality design and materials and that it promotes pedestrian activity in accordance with the Urban Design Element, North Beach Specific Plan and Zoning Code.

6.16 Provide a distinctive visual and physical environment for the public streetscape in accordance with the Urban Design Element, including standards for the use of consistent street trees, landscape (planters), street furniture (benches, trash receptacles, news racks, etc.), street and crosswalk paving, pedestrian-scaled lighting, public and entry signage, and other appropriate elements.

6.17 Ensure the built environment is clean and well-maintained through coordination with property owners, local businesses and residents and adequately staffed code enforcement.

6.18 Pursuant to the Bicycle and Pedestrian Master Plan, we prioritize bikeway and pedestrian improvements that improve connectivity to the beach, coastal bikeways/pathways, the Los Molinos Focus Area, Downtown, Pier Bowl, Marblehead Coastal, nearby residential neighborhoods, recreation amenities, and to areas outside of the City.

6.19 Consider improvements to our alleyways to provide alternative pedestrian and bicycle routes.

6.20 Through a combination of parking standards, provision of public parking and incentives, we ensure adequate parking for residents, employees and visitors.

6.21 Encourage the development of shared parking facilities and shared parking management techniques.

6.22 Use parking incentives (e.g., subsidies or provision of public parking) to stimulate historic preservation or other public purposes and reserve the right to subsidize parking to provide community-wide economic benefits.

6.23 Consistent with the Beaches, Parks and Recreation Element, we provide ample recreational facilities and programs for residents and visitors.

6.24 Support the conversion of automobile-related uses in the area to conforming uses, such as recreation, entertainment and retail sales. We prohibit new automobile-related uses 
and proactively work with property owners of existing auto-related uses to improve the visual impacts of their properties.

6.25 While entertainment uses are a focus of revitalization of the area, we require new development to be compatible with nearby residential uses through horizontal distance requirements and building and site design standards established by the Zoning Ordinance and Specific Plan.

6.26 Create public-private business partnerships to develop City owned property and other privately owned land, to serve as a catalyst to transform the district into an active, mixed-use, recreation and entertainment hub.

6.27 Encourage property owners to renovate or upgrade their properties through a combination of incentives, grants and other programs (e.g., façade improvement programs).

6.28 Accommodate neighborhood community and coastal visitor serving commercial, mixed use residential and commercial, and parking uses by establishing land uses as "MU 3PA", "MU 2-p-A" and "P-A" (see Table 3-1).

6.29 Allow for the development of a train station and/or multi modal transportation center and ancillary facilities.

Los Molinos

6.30 Recognizing the industrial heritage of the area and its economic benefits to the community, we allow current property owners and business to maintain and expand their operations, consistent with the General Plan and Zoning Code.

6.31 Routinely communicate and collaborate with existing property owners and businesses to understand their needs, identify strategies to improve their businesses and properties, and ensure compliance with City standards and regulations.

6.32 Encourage the transition of the Pico Plaza commercial center with a Professional/Office Overlay [link to land use designation] that requires a master plan for employment and or educational/institutional uses. The Pico Plaza is also identified in the Housing Element as having potential for mixed, residential and commercial uses with an affordable housing component. Existing uses, including residential uses that are consistent with the underlying Community Commercial land use designation, continue to be allowed. 
6.33 Require future planning efforts to redevelop the existing Pico Plaza commercial center to reserve an adequate portion of the site to accommodate a transportation center in the event that coastal railroad tracks are relocated inland.

6.34 Pursuant to the Bicycle and Pedestrian Master Plan, we prioritize bikeway and pedestrian improvements that improve connectivity to areas east of Interstate 5 and west to the North Beach area and strengthen connectivity to nearby parks, recreation and open space resources.

6.35 Encourage an eclectic mix of architecture, paint colors, landscaping and public art throughout the area, consistent with City Design Guidelines and the Urban Design Element.

6.36 Work with property owners, businesses and nearby residents to avoid, and where they occur, resolve conflicts between industrial operations and residents' quality of life.

6.37 Maintain entryways and an attractive, well-defined landscaped edge along Avenida Pico and Calle de Los Molinos to signify arrival to the City of San Clemente and the Los Molinos area.

Del Mar/T-Zone (Downtown)

6.38 Preserve historic resources in the Del Mar/T-Zone area by implementing policies and programs in the Historic Preservation Element, historic preservation incentives, and enforcement of our Zoning Ordinance. Development and redevelopment within the TZone should exhibit high quality design and materials, linking it to the City's historical roots and reinforcing this Area's role as the heart of San Clemente.

6.39 Prioritize and guide land uses, particularly retail uses, to the locations identified in the Del Mar/T-Zone Mixed Use Guide and consistent with the Land Use Plan and Zoning Code.

6.40 Allow flexibility to accommodate market changes for the mix of uses identified in the Del Mar/T-Zone Mixed Use Guide, if doing so furthers the vision of the area and improves livability, reduces vehicular trips, creates community gathering places and activity nodes, or helps strengthen the character and identity of the area.

6.41 Encourage the development of outdoor dining and other similar uses which do not impede pedestrian use of the sidewalks.

6.42 Pursuant to the Bicycle and Pedestrian Master Plan and General Plan Mobility and Complete Streets Element, provide a bicycle and pedestrian friendly environment 
through a combination of traffic calming design measures; sidewalks and paseos that provide pedestrian access to surrounding neighborhoods, automobile and bicycle parking areas, and other amenities; and appropriate bicycle and pedestrian facilities that connect to other key areas such as North Beach, the Pier Bowl, City Hall, Casa Romantica, North and South El Camino Real, the Pacific Coast bike route, and other beach recreational areas.

6.43 Maintain a distinctive visual and physical environment for the Del Mar/T-Zone area's public streetscape in accordance with the Urban Design Element, including the use of consistent street trees, landscape (planters), street furniture (benches, trash receptacles, news racks, etc.), street and crosswalk paving, pedestrian-scaled lighting, public and entry signage, and other appropriate elements

6.44 Where feasible, require new development to link individual buildings and sites with adjacent development through the use of walkways in addition to street-abutting sidewalks.

6.45 Provide adequate and accessible parking for visitors, employees and residents through a comprehensive program of: 1) paseos and signage that provide better linkage between parking lots, structures and the core commercial area; 2) more efficient use of the public and private parking facilities around the district that improve circulation and district patronage; 3) provision of adequate off-street parking for employees; 4) the identification of shared use opportunities; and 5) enforcement of parking standards.

6.46 Provide public spaces, such as courtyards, plazas and paseos community gatherings and civic events through a combination of development standards, incentives and the use of public property (e.g., adjacent to community facilities or the temporary use of Avenida Del Mar).

6.47 Encourage unique, locally-based businesses and services that help maintain and enhance Downtown's unique village character.

6.48 Provide for the needs of residents and tourists by establishing Downtown mixed use districts designated as "MU 3-p-A and MU 3-A" (See Table 3-1).

6.49 Accommodate the development of community and Coastal visitor-serving commercial uses, including retail, financial, household supply and furnishings, eating and drinking establishments, food sales, drug stores, personal and business services, professional offices, art and cultural facilities, entertainment, overnight accommodations, facilities, and similar uses. 
6.50 Accommodate the development of residential uses on the second floor or higher of structures containing commercial uses and or parking on the lower levels with exceptions possible through discretionary review for buildings on the City's Historic Structures List.

\section{Marblehead Coastal}

6.51. Implement the City's General Plan and be responsive to the goal of preserving San Clemente's unique atmosphere, historical identity and significant natural features.

6.52 Promote regional coastal shopping opportunities, provide job opportunities and enhance tax revenues economic activity to help provide and maintain public facilities and services.

6.53 Enhance existing and future coastal access opportunities.

6.54 Enhance public recreation opportunities along the shoreline by providing upland recreation and Coastal visitor-serving areas that support recreational use of public beaches in the City.

6.55 Provide additional housing opportunities, including affordable and mixed-use housing.

6.56 Ensure long-term protection and enhancement of on-site wetlands and native plants and animals.

6.57 Support the on-going management of on-site plant and animal habitat resources to ensure they are restored and protected, pursuant to the Marblehead Coastal Specific Plan.

6.58 Ensure that new land uses and related infrastructure is designed, built and maintained in a manner that will protect nearby marine resources and beaches.

6.59 Ensure long-term bluff stability to protect public safety, coastal access and coastal recreation opportunities. 
Table 3.1: Coastal Land Use Plan Classifications

\begin{tabular}{|c|c|c|}
\hline Land Use Designations & $\begin{array}{l}\text { Maximum Density/Building } \\
\text { Height }\end{array}$ & Intention \\
\hline \multicolumn{3}{|l|}{ Residential } \\
\hline Residential Very Low (RVL) & $\begin{array}{l}1 \text { unit per } 20 \text { gross acres } / 25 \\
\text { feet }\end{array}$ & $\begin{array}{l}\text { Single-family detached homes, typically in an } \\
\text { estate setting }\end{array}$ \\
\hline Residential Low (RL) & $\begin{array}{l}4.5 \text { units per gross acre } \\
7.0 \text { units per net acre }\end{array}$ & Single-family detached homes \\
\hline $\begin{array}{l}\text { Residential Medium Low } \\
\text { (RML) }\end{array}$ & $\begin{array}{l}7.0 \text { units per gross acre } \\
10.0 \text { units per net acre }\end{array}$ & $\begin{array}{l}\text { Single-family detached and attached homes, } \\
\text { including clustered homes and townhomes }\end{array}$ \\
\hline Residential Medium (RM) & $\begin{array}{l}15.0 \text { units per gross acre } \\
24.0 \text { units per net acre }\end{array}$ & $\begin{array}{l}\text { Single-family detached and attached homes, } \\
\text { including clustered homes and townhomes, and } \\
\text { multifamily apartments }\end{array}$ \\
\hline Residential High (RH) & $\begin{array}{l}24.0 \text { units per gross acre } \\
36.0 \text { units per net acre }\end{array}$ & $\begin{array}{l}\text { Single-family attached homes, including } \\
\text { townhomes and condominiums, and multifamily } \\
\text { apartments }\end{array}$ \\
\hline \multicolumn{3}{|l|}{ Commercial } \\
\hline Neighborhood Serving (NC) & $\begin{array}{l}\text { NC 1: } 0.35 \text { FAR } \\
\text { NC 2: } 0.50 \text { FAR } \\
\text { NC 3: } 0.75 \text { FAR }\end{array}$ & $\begin{array}{l}\text { Local-serving retail commercial, personal service, } \\
\text { professional office, lodging, cultural facilities and } \\
\text { eating and drinking uses }\end{array}$ \\
\hline Community Serving (CC) & $\begin{array}{l}\text { CC 1: } 0.50 \text { FAR } \\
\text { CC 2: } 0.75 \text { FAR }\end{array}$ & $\begin{array}{l}\text { More intense development of local- serving retail } \\
\text { commercial; personal service; professional } \\
\text { office; hospital, medical offices, congregate care, } \\
\text { and related uses; lodging; cultural uses and } \\
\text { eating and drinking uses }\end{array}$ \\
\hline Regional Serving (RC) & 0.50-2.00 FAR & $\begin{array}{l}\text { Regional-serving retail commercial, } \\
\text { entertainment, dining, financial and professional } \\
\text { offices }\end{array}$ \\
\hline $\begin{array}{l}\text { Coastal and Recreation } \\
\text { Serving (CRC) }\end{array}$ & 1.00 FAR & $\begin{array}{l}\text { Coastal-oriented retail commercial, recreation, } \\
\text { dining, and lodging }\end{array}$ \\
\hline Light Industrial (LI) & $\begin{array}{l}\text { LI 1: } 0.35-0.50 \text { FAR } \\
\text { LI 2: } 0.75 \text { FAR }\end{array}$ & $\begin{array}{l}\text { A mixture of business park, research and } \\
\text { development, professional offices, light } \\
\text { industrial uses such as light assembly and } \\
\text { manufacturing, and supportive retail. Limited } \\
\text { retail and service commercial uses supporting } \\
\text { these areas are allowed. }\end{array}$ \\
\hline Heavy Industrial (HI) & 0.75 FAR & $\begin{array}{l}\text { Industrial uses including vehicle storage, } \\
\text { warehousing, and wholesaling }\end{array}$ \\
\hline \multicolumn{3}{|l|}{ Mixed Use } \\
\hline MU 1 & $\begin{array}{l}\text { 0.35 FAR without residential } \\
\text { 1.0 FAR with residential } \\
>24.0-36.0 \text { dwelling units per } \\
\text { acre }\end{array}$ & $\begin{array}{l}\text { A vertical or horizontal mix of Neighborhood } \\
\text { Serving (NC) and Community Serving (CC). } \\
\text { Attached and multifamily housing is permitted } \\
\text { on the second floor or higher. }\end{array}$ \\
\hline MU 2 & $\begin{array}{l}\text { 0.50 FAR without residential } \\
\text { 1.5 FAR with residential } \\
>24.0-36.0 \text { dwelling units per } \\
\text { acre }\end{array}$ & $\begin{array}{l}\text { A vertical or horizontal mix of Neighborhood } \\
\text { Serving (NC), Community Serving (CC), and } \\
\text { multifamily housing. }\end{array}$ \\
\hline MU 3.1 & 1.00 FAR without residential & A vertical or horizontal mix of Neighborhood \\
\hline
\end{tabular}




\begin{tabular}{|c|c|c|}
\hline MU 3.2 & $\begin{array}{l}\text { 2.00 FAR with residential } \\
\text { >24.0-36.0 dwelling units per } \\
\text { acre } \\
\text { 1.00 FAR without residential } \\
\text { 1.50 FAR with residential } \\
>10.0-24.0 \text { dwelling units per } \\
\text { acre }\end{array}$ & $\begin{array}{l}\text { Serving (NC), Community Serving (CC), and } \\
\text { multifamily housing, coastal visitor-serving retail } \\
\text { commercial, lodging and dining. } \\
\text { A vertical or horizontal mix of Neighborhood } \\
\text { Serving (NC) and attached and multifamily } \\
\text { housing. }\end{array}$ \\
\hline MU 4 & $\begin{array}{l}2.00 \text { FAR } \\
>24.0-36.0 \text { dwelling units per } \\
\text { acre }\end{array}$ & $\begin{array}{l}\text { A vertical or horizontal mix of Neighborhood } \\
\text { Serving (NC) and Community Serving (CC). } \\
\text { Attached and multifamily housing is } \\
\text { permitted on the second floor or higher. }\end{array}$ \\
\hline MU 5 & $\begin{array}{l}0.35 \text { FAR } \\
>24.0-36.0 \text { dwelling units per } \\
\text { acre }\end{array}$ & $\begin{array}{l}\text { Neighborhood Serving (NC) commercial uses and } \\
\text { attached and multifamily housing. }\end{array}$ \\
\hline \multicolumn{3}{|l|}{ Public and Institutional } \\
\hline Civic Center (CC) & 0.35 & Government offices \\
\hline Institutional (I) & N/A & Private institutions and religious facilities. \\
\hline \multicolumn{3}{|l|}{ Open Space } \\
\hline $\begin{array}{l}\text { Open Space (Private) } \\
\text { Open Space (Public) }\end{array}$ & $\mathrm{N} / \mathrm{A}$ & $\begin{array}{l}\text { Privately owned parklands, recreational facilities, } \\
\text { and golf courses. } \\
\text { Publicly owned existing and dedicated parklands, } \\
\text { recreational facilities, and golf courses. }\end{array}$ \\
\hline \multicolumn{3}{|l|}{ Overlays } \\
\hline $\begin{array}{l}\text { Central Business District } \\
\text { (CB) }\end{array}$ & $\begin{array}{l}\text { As specified in underlying } \\
\text { land use designation. }\end{array}$ & $\begin{array}{l}\text { Signifies core commercial and mixed-use } \\
\text { districts where the City encourages } \\
\text { pedestrian uses in pedestrian oriented } \\
\text { locations, and encourages public spaces, } \\
\text { public sidewalks and street trees and related } \\
\text { amenities. }\end{array}$ \\
\hline Architectural Design (-A) & $\begin{array}{l}\text { As specified in underlying } \\
\text { land use designation. }\end{array}$ & $\begin{array}{l}\text { Uses permitted by the underlying land use } \\
\text { category; must be designed in accordance } \\
\text { with Spanish Colonial Revival standards } \\
\text { pursuant to the Urban Design Element, } \\
\text { Design Guidelines and Zoning Code. }\end{array}$ \\
\hline Coastal (CZ) & $\begin{array}{l}\text { As specified in underlying } \\
\text { land use designation. }\end{array}$ & $\begin{array}{l}\text { Refer to goals and policies of the Land Use } \\
\text { Plan and standards in the Local Coastal Plan } \\
\text { (LCP). }\end{array}$ \\
\hline Affordable Housing $(\mathrm{AH})$ & $\begin{array}{l}\text { As specified in underlying } \\
\text { land use designation. }\end{array}$ & $\begin{array}{l}\text { Refer to goals and policies of the Housing } \\
\text { Element. }\end{array}$ \\
\hline Medical Office & 0.75 FAR & $\begin{array}{l}\text { More intense development of medical and } \\
\text { professional offices. }\end{array}$ \\
\hline
\end{tabular}

\section{G. Planning and Development}




\section{Policy Intent}

Plan policy provides for planning and development principles that address the protection of San Clemente's Coastal Zone. In order to maintain coastal resources, it is important that development be designed in consideration of the following:

1) Public access to the beach

2) Minimize energy consumption, reduce air emissions, improve water quality

3) The visual resources of the Coastal Zone

4) Minimize risk to life and property

5) Ole Hanson Spanish Colonial Revival design traditions

6) Protection of sensitive habitat

7) Protection of coastal landforms

\section{Goal}

7. Ensure that planning and development within the Coastal Zone are sensitive to the area's unique character and maintain and enhance Coastal Zone resources.

\section{Policies}

Energy, Air Quality, and Water Quality

7.1 Design and manage development to minimize the introduction of pollutants into coastal waters (including the ocean, estuaries, wetlands, rivers, streams and lakes) to the maximum extent practicable.

7.2 Design and manage development to minimize increases in peak runoff rate, to avoid detrimental water quality impacts caused by excessive erosion or sedimentation.

7.3 Promote both the protection of unimpaired water quality and the restoration of impaired waters.

7.4 New development shall be sited and designed to protect water quality and minimize impacts to coastal waters by incorporating measures designed to ensure the following:

1) Protecting areas that provide important water quality benefits, areas necessary to maintain riparian and aquatic biota and/or that are susceptible to erosion and sediment loss.

2) Limiting increases of impervious surfaces.

3) Limiting land disturbance activities such as clearing and grading, and cut-and-fill to reduce erosion and sediment loss.

4) Limiting disturbance of natural drainage features and vegetation.

7.5 New development shall Minimize water consumption rates in San Clemente through site design, use of efficient systems, drought tolerant landscape and other techniques and implement National Pollutant Discharge Elimination System (NPDES) to prevent storm 
water run-off pollution in accordance with the Federal Clean Water Act. It shall not result in the degradation of the water quality of groundwater basins or coastal waters including the ocean, coastal streams, or wetlands.

7.6 Development must be designed to minimize, to the maximum extent feasible, the introduction of pollutants of concern that may result in significant impacts from site runoff from impervious areas.

7.7 New development shall:

1) Be consistent with requirements imposed by an air pollution control district or the State Air Resources Control Board as to each particular development

2) Minimize energy consumption and vehicle miles traveled

3) Implement the regional Air Quality Management Plan (AQMP) air quality mitigation measures for new development

Visual Resources

7.8 The scenic and visual qualities of coastal areas shall be considered and protected as a resource of public importance. Permitted development shall be sited and designed:

1) To protect public views to and along the ocean and scenic coastal area

2) To minimize the alteration of coastal bluffs and canyons

3) Where feasible, to restore and enhance visual quality in visually degraded areas

4) Require that projects be designed and developed to achieve a high level of quality, distinctive character, and compatibility with existing uses and development in accordance with this Element and the Urban Design Element

5) Encourage building elevations above the second floor to be set back from the street facing facade within the first 35 feet of property depth to minimize the impacts of height and bulk on abutting sidewalks and streets

6) Require that structures located in the Pedestrian Overlay Zone, as designated on the Coastal Land Use Plan, be sited and designed to enhance pedestrian activity along the sidewalks

7.9 The City's Coastal Development Permit process shall apply to all commercial and industrial developments within the Coastal Zone, as well as any residential development located along a coastal canyon or bluff (including public parking structures). The Coastal Development Permit process shall address itself to the potential for obstructing public views and the potential for altering or degrading an established public view. The standard of review shall be as follows:

1) Permitted development shall be sited and designed to protect views to and along the ocean and to scenic coastal areas, such as bluffs and canyons 
2) Permitted development shall be visually compatible with the character of the surrounding area

3) Permitted development shall, where feasible, restore and enhance visual quality in visually degraded areas

Hazardous Areas

7.10 New Development shall:

1) Minimize risks to life and property in areas of high geologic, flood, and fire hazard

2) Assure stability and structural integrity, and neither create nor contribute significantly to erosion, geologic instability, or destruction of the site or surrounding area or in any way require the construction of protective devices that would substantially alter existing landforms along bluffs and cliffs (PRC 30253)

7.11 Seek hazard avoidance as the primary method of minimizing exposure to coastal hazards.

7.12 Review all applications for new development, land divisions and plan amendments to determine the presence of hazards and, if they are present, ensure the hazards are avoided and/or mitigated.

7.13 Wide Beaches provide critical protection against storm surges and tsunami run-up, and we Participate in state and regional initiatives that address the protection, enhancement, and restoration of sand and other sedimentary deposits on our coastal beaches.

7.14 Monitor the issue of potential future sea level rise, both in the short term via permitting actions and a long-term response to address future development impacts along the shoreline.

7.15 Require shoreline development and bluff retention devices to be sited and designed to take into account predicted future changes in sea level. New structures shall be set back a sufficient distance landward to eliminate or minimize, to the maximum extent feasible, hazards associated with anticipated sea level rise, as established by Federal or State authorities, over the expected economic life of the structure.

7.16 Support efforts by other agencies to study the potential impacts of continued and accelerated sea level rise and flooding of water ways on the existing or proposed structures within all development zones, including impacts to development zones, traffic flow, public access, natural areas and water quality.

\section{Cultural Resources}

7.17 Protect cultural resources, including historical, archaeological or paleontological features, as identified by the State Historic Preservation Officer.

7.18 Ensure the City's architecture in key community and coastal-visitor serving areas maintains a high quality of design consistent with the City's history. 
7.19 Require that new, adaptively reused, and renovated buildings located in the Pier Bowl, Downtown and North Beach district be designed to reflect the City's Spanish Colonial Revival heritage in accordance with the Urban Design Element.

7.20 Require that the Casa Romantica building be preserved and that any rehabilitation or adaptive reuse be in accordance with the Secretary of Interior's Standards for the Treatment of Historic Properties.

7.21 We promote workshops, exhibits, programs, and events that celebrate the City's heritage and recognize the value and importance of San Clemente's historic resources as an economic development tool.

7.22 We work with public agencies, private and nonprofit organizations, property owners, area businesses and other interested groups and individuals to coordinate historic preservation activities, promote heritage tourism and provide public information on the value of historic preservation.

7.23 We work with property owners, businesses and non-profit organizations to promote walking tours, house tours, commercial building tours, signs, public art, and visitor attractions that showcase the City's history.

Sensitive Habitats

7.24 Protect Environmentally Sensitive Habitat Areas (ESHAs) by:

- Restricting development in ESHAs to those that are resource dependent, such as restoration, limited public access improvements, signage, placement of boardwalks, fencing minor educational, interpretative and research activities consistent with the California Coastal Act.

7.25 Utilize the Development Review process to protect and improve the natural biological value, integrity, and corridor function of coastal canyons and bluffs by prohibiting the encroachment of development, incompatible land uses and sensitive habitat disturbance into canyon and bluff areas.

7.26 A biological survey shall be conducted for all development potentially affecting environmentally sensitive habitat.

7.27 The City shall consult with the California Department of Fish and Game and U.S.F.W.S. on any project that could affect a species which is listed as rare, threatened or endangered. 
7.28 Require a Biological Assessment Report for any development located along a coastal canyon or bluff when the development results in the removal of any native vegetation and when an Initial Study has determined that there is a potential for a significant adverse impact to biological resources. The Biological Assessment Report shall:

1) Be prepared by a qualified professional and addresses the proposed project's impact on state and federally listed and candidate plants and animals; California Department of Fish and Game (CDFG) Special Animals; natural communities of high inventory priority with the CDFG's Nongame Heritage Program, and any other special interest species or communities identified in the General Plan Technical Background Report, or those hereafter named by state or federal trustee agencies;

2) Identify mitigation measures necessary to eliminate significant adverse impacts to sensitive biological resources; and

3) Define a program for monitoring and evaluating the effectiveness of the specified mitigation measures

7.29 Prohibit development and grading which alters the biological integrity of the Coastal Canyons as depicted on Coastal Canyon Map, Figure 2-1, unless it is replaced with habitat of equivalent value.

7.30 Encourage activities which improve the natural biological value, integrity and corridor function of the coastal canyons through vegetation restoration, control of alien plants and animals, and landscape buffering.

\section{Alteration of Landform Policies}

7.31 Development shall be concentrated on level areas (except on ridgelines and hilltops) and hillside roads shall be designed to follow natural contours. Grading, cutting, or filling that will alter landforms (e.g.: bluffs, cliffs, ravines) shall be discouraged except for compelling reasons of public safety. Any landform alteration proposed for reasons of public safety shall be minimized to the maximum extent feasible. Bluff stabilization and public safety is especially a concern along the bluffs that are adjacent to the Pacific Coast Highway north of Avenida Pico. It is, therefore, imperative that these bluffs be repaired and stabilized at the earliest possible date in a manner that maintains the public safety and is consistent with this Element.

7.32 Proposed development on bluff top lots shall be set back at least 25 feet from the bluff edge, or set back in accordance with a string line drawn between the nearest comers of adjacent structures on either side of the development. This minimum setback may be altered to require greater setbacks when required or recommended as a result of a geotechnical review.

7.33 New development shall not encroach into coastal canyons and shall be set back either: 
1) A minimum of $30 \%$ of the depth of the lot, and not less than 15 feet from the canyon edge; or

2) A minimum of $30 \%$ of the depth of the lot, and setback from the line of native vegetation (not less than 15 feet from coastal sage scrub vegetation or not less than 50 feet from riparian vegetation); or

3) In accordance with house and deck/patio string lines drawn between the nearest comers of the adjacent structures. The development setback shall be established depending on site characteristics and determined after an on site visit.

7.34 In developed areas, where new construction is generally infill, no part of a proposed structure, including decks, shall be built further onto a beachfront than a line drawn between the nearest adjacent comers of the adjacent structures. Enclosed living space in the new unit shall not extend further seaward than a second line drawn between the most seaward portions of the nearest comer of the enclosed living space of the adjacent structures.

7.35 New permanent structures shall not be permitted on a bluff face, except for engineered staircases or access ways to provide public beach access where no feasible alternative means of public access exists.

7.36 All proposed large scale development projects which have, or will have, ocean views shall prepare an analysis of the effect of the proposed project on public views. This analysis shall pictorially or photographically indicate the proposed site in its current state and compare it with an illustration showing the proposed building volume (at the same scale) in its proposed location.

7.37 Require that development be designed and sited to maintain the natural topographic and physiographic characteristics of the City's hillsides and canyons including the:

1) Minimization of the area and height of cuts and fills;

2) Minimization of pad sizes

3) Encouragement of the "stair stepping" of structures to conform to slopes (by use of retaining walls and other elements); and

4) Configuration of sites to reflect natural topography by the clustering of sites and units on lesser slope and avoiding extensive fragmentation of steeper slope and/or other techniques

\subsection{Shoreline Access Goals and Policies}

The Coastal Act directs local governments to provide for maximum public access to the shoreline. Access should be consistent with public safety, protect public rights, protect rights of private property owners, and protect natural resources from over use (PRC 30210). The City has a total of 18 public access points that provide excellent access opportunities to both City and 
State beaches. There are, however a number of private beach areas where public access is presently not available. Providing public access to these private areas and further improvement to existing public access is desirable.

\section{A. Circulation/Transportation/Parking Policies Policy Intent}

Plan policy provides for both the preservation and the addition of transportation and circulation to coastal access points and coastal activity centers.

\section{Goal}

8. Provide a circulation/transportation and parking system within the Coastal Zone to:

1) Support existing, approved, and planned land uses throughout the Coastal Zone while maintaining a desired level of service on all streets and all intersections

2) Support development of regional transportation facilities which ensure the safe and efficient movement of people to, from, and within the Coastal Zone; encourage fewer people to drive, reducing circulation and parking demand and promotes the focal areas within the Coastal Zone as a destination resort area

3) Provide a citywide system of safe, efficient and attractive bicycle and pedestrian routes for commuter, school, and recreational use

4) Provide sufficient, well-designed and convenient on-street parking and off-street parking facilities throughout the City

5) Develop and maintain an effective public trail system, including bicycle, hiking, and equestrian trails

\section{Policies}

\section{Circulation}

8.1 Create a network of accessible and prominent public places with clear perceptual, symbolic, and circulation linkages between them.

8.2 Develop a citywide identity graphics program to clearly mark directions to public buildings, parks, the beach front, Del Mar business district, the Pier Bowl, North Beach, public parking areas, prominent natural features, and City entry points.

8.3 Evaluate and implement, as feasible, a pedestrian "promenade" connecting North Beach with the Pier Bowl and south to Calafia Beach.

8.4 Combine the aims of the State Trails Plan, the County Equestrian Trails Plan, the Local Coastal Plan, and the Circulation Element of the City General Plan into a unified and coordinated trails plan for San Clemente.

Bicycle Circulation 
8.5 Designate pedestrian and bike routes that link selected public places to encourage walking and exercise, and help visitors experience the City's attractions without complete reliance on the automobile, pursuant to the Bicycle and Pedestrian Master Plan.

8.6 Implement the Bicycle and Pedestrian Master Plan, which is consistent with the County of Orange Master Plan of Countywide Bikeways and other adopted master plans, to ensure that local bicycle routes will be compatible with routes of neighboring jurisdictions.

8.7 Require plans for bicycle and pedestrian facilities to give priority to providing continuity and closing gaps in the bikeway and sidewalk network.

8.8 The City shall develop bike routes to the primary and secondary beach access points, and shall place directional signs and bike racks at each primary and secondary access point. The area immediately fronting each access may be considered for red curbing to make the access way more visible.

8.9 The determination of the appropriate type of bicycle facility should primarily be based upon safety requirements. There are three classifications:

- Bicycle paths (Class 1) should be utilized as much as possible for regional and community trails, but not for those designated on small local streets where traffic volume is minimal.

- Bicycle lanes (Class 2) should be utilized as necessary links to bicycle paths or local routes where paths are not feasible.

- Bicycle routes (Class 3) should be utilized for necessary links or as interim links prior to the implementation of bicycle lanes or paths. Implementation includes signage and may include roadway markings.

8.10 Bicycle facilities should be designed to facilitate cycling by incorporating Caltrans Chapter 1000 standards to the extent practical to reduce slopes, sharp curves and interference with vegetation, pedestrians and motor vehicle traffic (See Appendix I: Caltrans Highway Design Manual Chapter 1000).

8.11 Bicycle paths should be incorporated into the design of community land use plans, capital improvement projects and in parks and open space as specified in the General Plan.

8.12 The City should coordinate regional trail and bicycle planning, acquisition and development efforts with adjacent jurisdictions.

8.13 The City should make certain that regional and/or community routes within the City link up with existing or proposed routes within neighboring jurisdictions. 
8.14 Consider every street in San Clemente as a street that cyclists will use and employ bicycle-friendly design using new technologies and innovative treatments as appropriate.

Transportation

8.15 Coordinate with OCTA and other appropriate entities to improve bus service to and within San Clemente.

8.16 Increase commuter trail opportunities for both residents and employees of the City and regional rail service for visitors.

\section{Parking}

8.17 Develop and implement a Parking Management Plan or other programs that identify citywide parking requirements.

8.18 Provide better transit and parking opportunities both on street and in designated lots, and/or inland parking with beach transportation.

\section{B. Coastal Access Policies}

Maximum public coastal access is a fundamental goal of the Coastal Act and a key part of San Clemente's charm. But the Coastal Act goes beyond just ensuring physical access. It also emphasizes the importance of recreation and visitor-serving land uses that meet a wide range of incomes and interests.

\section{Policy Intent}

Provide for maximum shoreline access and recreational opportunities in the Coastal Zone and ensure that new development shall not interfere with the public's right of access to the sea where acquired through use or by legislative authorization.

\section{Goal}

9. To create and maintain outstanding public access in the Coastal Zone, consistent with effective resource conservation practices and the protection of private property rights.

9. Provide and maintain a comprehensive and safe beach access network and improve the City's public coastal access system wherever possible.

\section{Policies}

9.1 The location and amount of new development should maintain and enhance public access to the coast by: 
1) Facilitating the provision or extension of transit service;

2) Providing commercial facilities within or adjoining residential development or in other areas that will minimize use of coastal access roads;

3) Providing multi-modal facilities and access routes within and adjacent to the development;

4) Providing adequate parking facilities or a substitute means of serving the development with public transportation or non-motorized transportation modes;

5) Ensuring the potential for public transit for high intensity uses;

6) Ensuring that the recreational needs of new residents will not overload nearby coastal recreation areas, by correlating the amount of development with local park acquisition and development plans with the provision of on site recreational facilities to serve the new development.

9.2 Improvements to beach facilities and beach access points which are administered by the City of San Clemente shall specifically be intended to maintain, enhance and maximize public use of the beach and ocean.

9.3 The maintenance and enhancement of public non vehicular access to the shoreline shall be of primary importance when evaluating any future public or private improvements in the Coastal Zone. IX.5 The City's five primary beach access points are:
1) North Beach
2) Linda Lane
3) Pier Bowl
4) " $T$ " Street
5) Avenida Calafia (San Clemente State Beach)

9.4 The following five secondary access points are:
1) Dije Court
2) El Portal
3) West Mariposa
4) Lost Winds
5) Riviera

The City shall encourage non vehicular access to these points, in order to minimize conflict with local residential neighborhoods and to maximize the capacity of the primary access points to serve regional visitors.

For the private beach area north of Capistrano Shores and the Capistrano Shores, La Ladera, Cypress Shores and Cotton's Point, private communities shall be prepared when development in one of these private communities is required to dedicate or offer to 
dedicate public access dedication in accordance with this Element and State requirements. The purpose of the access management programs shall be to provide maximum public access consistent with the Coastal Act of 1976, the analysis contained in this Element, and site specific constraints. The access management programs shall be implemented by the City of San Clemente or other public agencies or private associations which have accepted the offers of dedication.

1. The access management program shall include the following:

a. Establishment of hours of public access which shall include, at minimum, the hours between sunrise and sunset.

b. The provision of bicycle racks for a minimum of 25 bicycles at the beach terminus of the vertical access way.

c. The provision of signing at the entrance to the private communities in order to make the public aware of the existence of the access way and its hours of operation.

d. The provision of a public restroom facility. 


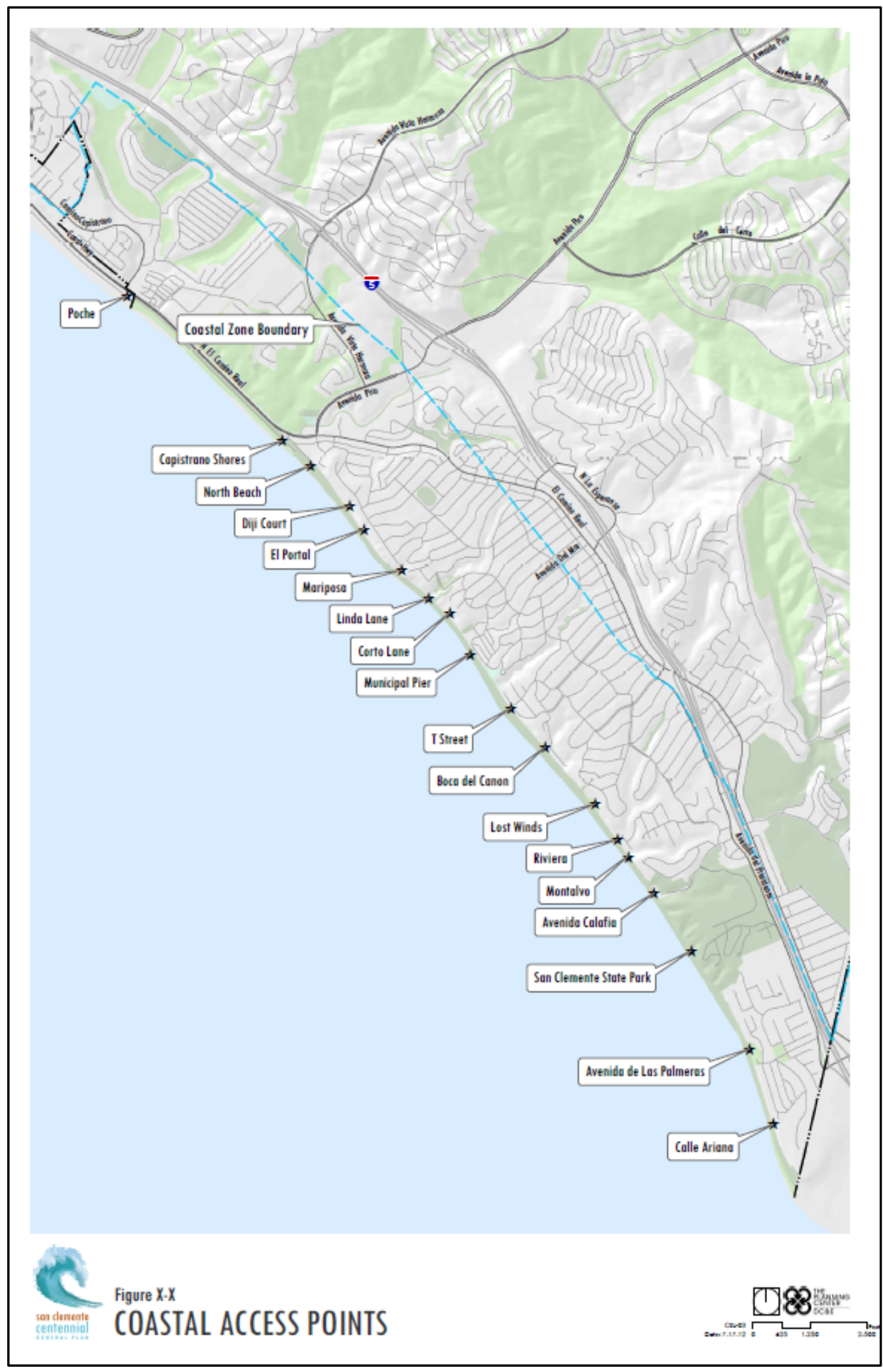

Figure 3.2: Coastal Access Points 


\subsection{Access management programs}

2. The following elements may be incorporated into the management program:

a. The accepting agency may charge a reasonable entrance or use fee, comparable to those charged by the State and City operated day use facilities, in order to defray costs for maintenance.

b. The community association may be allowed, subject to permit approval, to erect small posts, bollards or similar structures at reasonable intervals in order to delineate the public access and recreation areas. Small signs describing the uplands as private property may also be allowed, subject to permit approval. No fences may be erected on the beach.

9.6 Public access from the nearest public roadway to the shoreline and along the coast shall be provided in new development projects except where:

a. It is inconsistent with public safety, military security needs or the protection of fragile coastal resources;

b. Adequate access exists nearby; or

c. Agriculture would be adversely affected.

9.7 New developments lying between the first public roadway and the shoreline shall provide both physical and visual access to the coastline.

1) Any new development proposed by the private communities listed below shall be required to provide an irrevocable offer of dedication of an easement to allow public vertical access to the mean high tide line. Such offers of dedication shall run with the land in favor of a public agency or private association approved by the Executive Director of the Coastal Commission. Such offers shall be in effect for a period of twenty-one (21) years, and shall be recorded free of prior liens, except tax liens. The access easement shall measure at least 10 feet wide. Development permits will require public vertical access for new development at the following private communities:

a. Private beach areas between Capistrano Shores and the northern City limit

b. Capistrano Shores Mobile Home Park

c. La Ladera (La Boca del Canon)

d. Cypress Shores (Avenida de las Palmeras/Calle Ariana)

e. Cotton's Point 
Access dedication requirements shall apply only to the extent permissible under the "takings" clauses of the United States and California Constitutions. (Refer to Shoreline Access Policy IX. 19). Any new development lying between the first public roadway and the coast which has ownership interests to the mean high tide line shall be required to provide an irrevocable offer of dedication of an easement to allow public lateral access along the beach. Such offers of dedication shall run with the land in favor of a public agency or a private association approved by the Executive Director of the Coastal Commission. Such offers shall be in effect for a period of 21 years, and shall be recorded free of prior liens, except tax liens. The lateral access easement shall extend inland from the mean high tide line to the toe of a bluff. In cases where development is not located on a bluff, but on the beach, lateral access shall extend no closer than 10 feet to a residence to allow for a privacy buffer. In no case shall the area available for public use be closer than ten (10) feet to any residence with the exception that in the event that the area seaward of the 10-foot buffer is impassable. For example, at extreme high tides, the public shall have the right of pass and repass within the 10 -foot buffer area.

2) Where no beach area exists and a residential development of greater than twenty units is proposed along a shore front bluff top lot, public access for view purposes shall be provided rather than lateral access along the shoreline. Such access shall run along the bluff edge, and shall extend a minimum of twenty feet inland from the bluff edge, but no closer than ten feet to any residential unit.

3) Modifications to the recommended dimensions of bluff top viewing areas shall be permitted in order to maintain public safety (including bluff stability), habitat values and the rights to privacy of the property owner and adjacent property owners. In areas where a residential structure exists in the vicinity of the proposed access, the access way shall be sited and designed to provide a buffer area between the access way and the structure. Generally, a 10-foot buffer between the access way and the residential structure will be adequate to protect the right to privacy of those potentially affected. This dimension, however, may be enlarged or diminished depending on individual site characteristics.

9.8 For purposes of this section, "new development" does not include:

1) Replacement of any structure pursuant to the provisions of Subdivision (g) of Section 30610 of the Public Resources Code.

2) The demolition and reconstruction of a single family residence, provided that the reconstructed residence shall not exceed either the floor area, height, or bulk of the 
former structure by more than ten percent and that the reconstructed residence shall be sited in the same location on the affected property as the former structure.

3) Improvements to any structure which do not change the intensity of its use, which do not increase either the floor area, height or bulk of the structure by more than 10 percent, which do not block or impede public access, and which do not result in a seaward encroachment by the structure.

4) Any repair or maintenance activity for which the Coastal Commission has determined, pursuant to Section 30601, that a coastal development permit will be required unless the Commission determines that such activity will have an adverse impact on lateral public access along the beach.

9.9 For the purpose of determining when a project is required to provide access, the following shall be considered:

1) Access dedication requirements shall apply only to the extent permissible under the "takings" clauses of the United States and California Constitutions.

2) The provision and protection of public access to the shoreline can be considered a "legitimate governmental interest." If the specific development project places a burden on this interest, then the City may have grounds to deny the development or impose conditions on the development to alleviate the burden.

3) The following questions should be addressed to determine whether or not a development project places a burden on public access which would justify either requiring the dedication of public access or recommending denial of the project:

a. Does the project physically impede or block an area used for public access?

Example -- Does the project block access established by an easement or ownership? If the answer is "yes", then the City may deny the project or require that the project be modified to preserve the existing access easement.

b. Does the project interfere with public access rights that have been "acquired through use"?

Example -- Is there reasonable evidence that the project may block a prescriptive easement? If there is evidence of a prescriptive easement, then the City may recommend postponing the project until the landowner establishes clear title. If a prescriptive easement exists, then the City may deny the project or require that the project be modified to preserve the access easement.

c. Does the project encroach on public land? 
Example -- Development projects located seaward of the terrestrial vegetation line or bluffs may be located on public trustlands. If the project is located seaward of the bluffs then the City may recommend postponing the project until the landowner establishes clear title. If the project encroaches on public land, then the City may deny the project, or require that the project be removed from public land or require that the project be modified to provide public access.

d. Does the project individually or cumulatively impact public access to or along the coast?

Example --Projects which may create impacts or substantially increase use of the shoreline are the construction of seawalls, an increase in the density or intensity of uses through the subdivision of property, and/or the addition of visitor serving commercial uses on the coast.

If the answer is "yes", then the City must make findings supported by evidence which state how the proposed development project negatively impacts public access. These findings may serve as justification for requiring public access as a condition of approval for the project. A yes answer to this question should be accompanied by a yes answer to Question 5 and a no answer to Question 6 in order to create a strong case for requiring access. If the answer is "no", then public access cannot be required as a condition of approval for the development.

e. Will the proposed regulation or condition alleviate the burden imposed on the public access interest?

Example -- There must be a direct connection between the regulation proposed and the burden created by the development.

If the answer is "yes", then public access may be justified as a condition of approval for the development. The City should state clearly how the access condition alleviates the burden. If the answer is "no", then public access cannot be justified as a condition of approval for the development.

f. Does the regulation or condition preclude all reasonable economically viable use of the property?

If the answer is "yes", then the regulation or condition may be considered a "taking." If the answer is "no", then public access may be justified as a condition of approval for the development. 
9.10 Trash receptacles shall be placed at appropriate access ways and should be placed in aesthetically pleasing enclosures.

9.11 Establish, maintain, and, where feasible, expand public coastal access to the shoreline, beaches, tidelands, and recreational facilities in a manner that:

1) Maximizes public access to and along the shoreline;

2) Is safe and feasible;

3) Includes, where appropriate, pedestrian, hiking, bicycle, and equestrian trails;

4) Provides connections to beaches, parks, and recreational facilities and trail networks with adjacent jurisdictions;

5) Includes, where appropriate, well designed and maintained support facilities such as parking, restrooms, fire pits, trash facilities, resting/view places, snack bars, picnic tables, and bike racks.

6) Maximizes coastal views;

7) Facilitates alternative modes of transportation, such as walking and bicycling;

8) Is consistent with policies regarding hazards, bluff, resource, cultural resource and wildlife habitat preservation;

9) Minimizes alterations to natural landforms;

10) Protects environmentally sensitive habitat areas (ESHAs);

11) Meets facility needs to provide public safety services, including lifeguards, fire, and police service;

12) Is managed to be permanently available;

13) Balances the rights of individual property owners with the public's rights of access;

14) Is compatible with adjacent development; and

15) Is developed in cooperation with the State Department of Parks and Recreation, the State Department of Fish and Game, the State Coastal Conservancy, State Lands, the County of Orange, and private organizations.

9.12 Seek public access to private beach areas, where feasible.

9.13 Review proposals for coastal land use and development to ensure they do not interfere with the public's right of access by ensuring that:

1) Public Transit needs are accommodated, as required by OCTA;

2) Commercial and visitor-serving commercial uses are located near housing to encourage walking and bicycling;

3) Non-automobile mobility options are provided within new development;

4) Adequate parking facilities, or a substitute means of serving the development with public transportation, is provided;

5) Proposals are consistent with public safety and security needs; 
6) Proposals protect fragile coastal resources and effectively mitigate potential impacts;

7) Public coastal access is provided unless there is a convenient and easily accessible alternative nearby.

8) Gates, guardhouses, barriers, or other structures that would inhibit public access to and along the shoreline and to beaches, coastal parks, trails, or coastal bluffs are generally not permitted, with the exception of devices associated with safe access along and across the railroad.

9.14 Promote non-vehicular access in the Coastal Zone in order to minimize parking conflicts and to enhance our ability to serve regional visitors.

9.15 Protect and enhance public infrastructure that provide public access to the shoreline, beaches, coastal parks, and trails.

9.16 Support the establishment of the California Coastal Trail by others and where financially feasible, assist in its implementation.

\subsection{Recreation and Coastal Visitor-Serving Facilities Goals and Policies}

Coastal Act policies (PRC 30212.5, 30213, 30220-30223 and 30250 (c)) require provisions for public and low cost recreation and visitor serving facilities by requiring that suitable land be designated for these uses and that they be given priority. This plan contains policies and land uses designed to maintain and expand the mixture of both public and private recreational and visitor serving facilities in the City. Visitor serving facilities include public and private development that provides service, food or accommodations. Some of the existing coastal visitor-serving uses within the San Clemente Coastal Zone include hotels, motels, bed and breakfast inns, youth hostel, time share units, campgrounds, restaurants, public parking lots, motion picture theater, specialty retail and other commercial recreational development.

\section{A. Coastal Visitor-Serving Facilities Policies}

San Clemente offers many opportunities to use and enjoy the coast, including the many public beaches, the historic Municipal Pier, the Ole Hanson Beach Club, ocean front parks, the California Coastal Trail, which includes the City's Beach Trail, runs the length of the City Amtrak and Metrolink train facilities, and numerous public access trails that link the community with the Pacific Ocean. San Clemente also provides 445 rooms in the Coastal Zone which can serve coastal visitors. Coastal visitor-serving facilities are concentrated in the Camino de los Mares, Los Molinos, North Beach, El Camino Real, Del Mar/T-Zone, and Pier Bowl areas. Visitor-serving facilities include hotels, motels, bed and breakfast inns, a youth hostel, time share units, campgrounds, restaurants, public parking lots, specialty retail, and other commercial recreational development. 
There are twelve coastal visitor-serving facilities (hotels, motels and inns) listed in Table 3.2, as well as an estimated 3009 vacation rental units.

Table 3.2: Hotels, Motels and Inns within the Coastal Zone

\begin{tabular}{|l|c|c|}
\hline \multicolumn{1}{|c|}{ Name } & Address & Number of Rooms \\
\hline Beachcomber & 533 Avenida Victoria & 9 \\
\hline Casa Tropicana & 610 Avenida Victoria & 63 \\
\hline Casablanca Inn & 1601 N. El Camino Real & 72 \\
\hline Days Inn & 1301 N. El Camino Real & 100 \\
\hline Holiday Inn & 111 S. Ave. De Estrella & 2 \\
\hline Holiday Inn Express & 35 Calle De Industrias & 14 \\
\hline La Casa Oceana & 507 Avenida Victoria & 34 \\
\hline Patriots Motel & 711 S. El Camino Real & 97 \\
\hline San Clemente Cove & 104 S. Alameda & 11 \\
\hline San Clemente Inn & 6002 Ave. Del Presidente & 8 \\
\hline Sea Horse Inn & 612 Avenida Victoria & 445 \\
\hline Villa Del Mar Inn & & \\
\hline Total & & \\
\hline
\end{tabular}

\section{Policy Intent}

Coastal Land use Plan policies provide for maintaining and enhancing the variety of visitor serving uses in the Coastal Zone. These uses will continue to be located throughout the Coastal Zone.

\section{Goal}

10. Protect, promote, and provide visitor-serving facilities in San Clemente's Coastal Zone.

\section{Policies}

Coastal Act

10.1 Wherever appropriate and feasible, public facilities, including parking areas or facilities, shall be distributed throughout an area so as to mitigate against the impacts of overcrowding or overuse by the public of any single area (PRC 30212.5).

10.2 Provide for oceanfront land suitable for recreational use and development, unless present and foreseeable future demand for public or commercial recreational activities can be accommodated by existing development (PRC 30221).

10.3 The use of private lands suitable for visitor serving commercial recreational facilities designed to enhance public opportunities for coastal recreation shall have priority over 
the private residential, general industrial or general commercial development, but not over agriculture or coastal dependent industry (PRC 30222).

City

10.4 The City shall provide improved public facilities to serve the needs of beach users. These facilities include:

1) Restrooms

2) Snack bars

3) Picnic tables

4) Public parking lots and/or structures

10.5 The City is limited in its ability to implement the policies for beaches, recreation and coastal visitor-serving facilities in that the street and parking system is inadequate and there are not sufficient funds to upgrade and maintain them.

10.6 Protect, promote, and provide sustainably-designed recreational and visitor-serving facilities in San Clemente's Coastal Zone as described in the General Plan Land Use Designations.

10.7 Support the continued improvement of the Pacific Coast Bicycle Route and where financially feasible, assist in its implementation

10.8 The City supports recreational coastal fishing.

10.9 Lower cost visitor and recreational facilities shall be protected, encouraged, and, where feasible, provided. Developments providing public recreational opportunities are preferred.

10.10 The use of private lands suitable for visitor-serving commercial recreational facilities designed to enhance public opportunities for coastal recreation shall have priority over private residential, general industrial, or general commercial development, but not over agriculture or coastal-dependent industry.

10.11 Visitor-serving facilities that cannot feasibly be located in existing developed areas shall be located in existing isolated developments or at selected points of attraction for visitors.

Shore cliffs

10.12 Accommodate the development of a hotel, time share facilities, and ancillary restaurants, gift shops and other facilities at the Shore cliffs Golf Course site. 
Pier Bowl/North Beach

10.13 Existing recreation and visitor serving uses, including public parking facilities, in the Pier Bowl and North Beach areas shall be protected. Mixed use developments which provide for both residential and commercial uses on the same lot or in the same building shall be permitted. In new development proposed for the first block of Avenida Victoria, only visitor serving uses shall be permitted on the ground floor level. Off site parking may be permitted for these commercial uses if provided in the Pier Bowl area. In no case, however, shall off site parking displace existing visitor serving and beach recreational parking on Avenida Victoria or in the Pier Bowl area.

10.14 It is the City's policy to encourage the following proposals/amenities in the Del Mar/Pier Bowl area and the Pico/North Beach area.

Specific proposals for the Del Mar/Pier Bowl area include:

1) The renovation and/or recycling of existing uses along Del Mar and in the Pier Bowl with a trend towards specialty retail uses, such as currently existing along Del Mar.

2) Improvement of design guidelines that encourage Spanish Colonial Revival architecture and pedestrian circulation.

3) A tram which would stop in the shopping areas and service the beach during the peak summer season.

4) A streetscape and sign program that directs traffic from Interstate 5 into and out of the Pier Bowl.

Specific proposals for the Pico/North Beach area include:

1) Accommodate neighborhood community and visitor serving commercial, mixed residential and commercial, and parking uses.

2) The development of a train station and/or multi modal transportation center and ancillary facilities.

3) Allow for the development of expanded recreational uses at the Ole Hanson Beach Club and surrounding areas, including the potential of an active park at the existing parking lot provided that existing parking is adequately replaced.

4) A streetscape and sign program.

5) Development of design guidelines that encourage Spanish Colonial Revival Architecture and pedestrian circulation.

\section{Tourism/Economic Development}

10.15 Allocate public resources among various tourism efforts based on the City Councilapproved Economic Development Strategy. We require those who wish to change the allocation of public resources for tourism to demonstrate that their requests will help 
achieve the Economic Development Strategy in concert with Economic Development Element goals.

10.16 Give priority to City Council decisions, initiatives, investments, and development approvals that provide consistent overnight tourism benefits throughout the year over decisions, initiatives, investments, and development approvals that only increase seasonal or day-trip tourism.

10.17 Give priority to City Council decisions, initiatives, investments, and development approvals that increase tourism outside of the summer season ahead of decisions, initiatives, investments, and development approvals that increase tourism only in summer months, thereby creating a more consistent benefit throughout the year.

10.18 Continuously seek ways to increase the net fiscal benefits from tourism and to efficiently allocate revenues to implement the economic development strategy.

10.19 Recognize the value of surfing and the surfing industry to the City's heritage and economy. We encourage the preservation and growth of this aspect of the City's cultural and economic fabric.

10.20 Recognize heritage tourism as an integral part of our Economic Development Strategy (link to Heritage Promotion section of the Historic Preservation Element).

10.21 Leverage our position as a regional coastal route to capture bicycle tourism.

\section{B. Recreation Policies}

\section{Policy Intent}

The shoreline, Municipal Pier, the Ole Hanson Beach Club and ocean front parks provide the primary recreational resources in the City's Coastal Zone. Plan policy provides for the preservation and enhancement of these existing recreational resources and the development of new recreational opportunities whenever feasible to maintain and enhance the quality of life for the City.

\section{Goal}

11. Protect, and where feasible, expand and enhance recreational opportunities in the Coastal Zone.

11. Protect, promote and provide recreational uses in San Clemente's Coastal Zone.

\section{Policies}


11.1 Protect, and where feasible, expand and enhance recreational opportunities in the Coastal Zone as addressed in the General Plan Land Use Designations and Beaches, Parks and Recreation Element.

11.2 Prohibit uses on beaches that interfere with public access and enjoyment of coastal resources.

11.3 Establish and maintain public beaches and parks to provide free and lower-cost recreational opportunities.

11.4 Maintain, improve and develop our recreational resources in ways that preserves and enhances the natural beauty of the coast.

Coastal Act

11.5 Coastal areas suited for water oriented recreational activities, including surfing, body boarding, body surfing and other activities that can not readily be provided at inland water areas shall be protected for such uses (PRC 30220).

11.6 Upland areas necessary to support coastal recreational uses shall be reserved for such uses, where feasible (PRC 30223).

City

11.7 Designate lands for the provision of recreational open spaces on the Coastal Land Use Plan Map which are sufficient to meet the needs of existing and future residents.

11.8 Protect the City's recreational resources including the recreational facilities, parks, Beaches, surfing areas, and community events identified in this Plan.

11.9 Provide for the acquisition and development of parks and recreational lands and facilities in accordance with the Growth Management Element.

11.10 Expand and continue existing public and private cultural and fine art facilities and activities.

11.11 Maintain a calendar of City sponsored arts and cultural events and local.

11.12 Incorporate elements of art, where feasible, in the City's key activity and pedestrian oriented districts, as defined by the City's Land Use Element.

11.13 Increase the community's involvement in the use of recreational spaces encouraging recreational opportunities unique to San Clemente which will contribute to continuing visitation and economic development.

11.14 Maintain the valuable beach resources as a fundamental element to conserve and develop sensitively, thus enhancing the quality and livability of the City of San Clemente.

11.15 Locate and enhance the beach areas that will accept limited recreational development without destroying existing natural beauty.

11.16 Park sites with significant historic or natural features should be combined with recreational learning opportunities wherever possible. 
11.17 Emphasize the protection, enhancement, and sensitive development of park and open space areas which possess great scenic, environmental, historic, and cultural values.

11.18 Provide for a balance of community needs and public financial constraints when undertaking site-specific park planning and design.

11.19 Require beach concessionaires to provide a good variety, price and quality of service to the general public.

11.20 Prohibit uses on beaches that interfere with public access and enjoyment of coastal resources.

11.21 Establish and maintain public beaches and parks to provide free and lower-cost recreational opportunities.

11.22 Maintain, improve and develop our recreational resources in ways that preserve and enhance the natural beauty of the coast.

11.23 We monitor beach use and quality to help ensure adequate staffing, facility and environmental maintenance, and sand replenishment planning.

11.24 We encourage connectivity by developing and maintaining pedestrian and bicycle trails, where appropriate, along our coastline, including safe railroad crossings for pedestrians.

11.25 We enhance the Pier Bowl and North Beach areas to function as recreational, cultural and economic hubs. We also maximize accessibility for residents, visitors and commuters, including train passengers, to create easy and natural transitions between the beach, beach trail and local businesses or cultural attractions.

11.26 We provide an appropriate level of Marine Safety personnel and facilities for the protection of beach users at City beaches. (See Safety Element Marine Hazards section)

11.27 We support the eventual relocation of the railroad right-of-way away from the beach to the vicinity of the Interstate 5 freeway.

11.28 We encourage public participation in protecting our beaches through educational outreach programs.

11.29 We support sand nourishments programs and other measures to enhance the use, appearance and safety of our beaches.

\section{Temporary Events}

11.30 Temporary events shall minimize impacts to public access, recreation and coastal resources. Such access shall be protected for temporary events that meet the following criteria: 1) held between Memorial Day and Labor Day; and 2) involve a charge for general public admission where no fee is currently charged for use of the same area. Public access shall also be protected during temporary events. 


\subsection{Coastal Visual and Historic Resources Goals and Policies}

Coastal Act policies (PRC 30251 and 30253(5)) require the protection of scenic and visual qualities of coastal areas and the preservation of special communities. The aesthetic resources of the City's Coastal Zone include coastal bluffs, coastal canyons, and scenic public views. Historic resources include areas characterized by a particular cultural, historical, or architectural heritage that is distinctive in the Coastal Zone. Founded by Ole Hanson in 1925, San Clemente was developed as a "Spanish Village by the Sea." Development followed a unifying theme which required white stucco buildings with red tile roofs. Many of San Clemente's earlier Spanish style residential, commercial and public buildings remain, lending a unique Spanish architectural character to San Clemente's Coastal Zone.

\section{A. Visual Resource Policies \\ Policy Intent}

Plan policy provides for maintaining the visual character and aesthetic resources of the City through the preservation of: open space areas, coastal bluffs and canyons and public view corridors.

\section{Goal}

12. Maintain the visual quality, aesthetic qualities and scenic public views in the Coastal Zone.

\section{Policies}

12.1 Preserve the visual character and aesthetic resources of the City, including coastal bluffs, visually significant ridgelines, and coastal canyons, open spaces, prominent, mature trees on public lands, and [significant or designated] public views.

12.2 Provide for the preservation and restoration of the sites, structures and districts and cultural landscapes which have architectural, historical, archaeological, and/or cultural significance.

12.3 Review and require changes to development proposals to minimize obstructions of designated public coastal views and view corridors, and to ensure public and private development projects in the Coastal Zone are of high-quality materials, and designed to be attractive and aesthetically compatible with adjacent structures, site improvements, utilities and landscape features.

12.4 Identify and designate the location and orientation of significant public scenic view corridors.

12.5 Require the following coastal roadways be maintained and preserved as scenic corridors in accordance with the City's Master Landscape Plan for Scenic Corridors:

1) Avenida Pico 
2) El Camino Real/Pacific Coast Highway

3) Ola Vista

4) El Camino Real

5) Camino de Estrella

12.6 Emphasize key entry points into the Scenic Corridors by providing simple design statements such as monument signs, public art and/or plantings to designate key entry points into the scenic highway system.

12.7 Promote the restoration of the coastal canyons as a visual resource in a manner that is consistent with the goals of the California Coastal Commission and the City's Land Use Plan.

12.8 Work in conjunction with the California Coastal Commission with the expressed intent to develop implementation programs that will preserve and maintain the physical features of the Coastal Zone including bluffs, canyons and beaches.

12.9 Promote the preservation of designated public view corridors to the ocean.

\section{B. Historic Resource Policies}

\section{Policy Intent}

Plan policy provides for the preservation and restoration of the sites, structures and districts which have architectural, historical, archaeological and/or cultural significance to the City of San Clemente.

\section{Goal}

13. Ensure that the City's historically and archaeologically significant resources are protected in a manner that preserves and/or enhances the resources' inherent historic values.

\section{Policies}

13.1 We support the preparation of a comprehensive survey of cultural resources, historic vegetation and archaeological resources that encompasses the entire City and its sphere of influence, as well as update the City's inventory of historic resources.

13.2 Through the design review process, encourage that new development is compatible with adjacent existing historic structures in terms of scale, mass, building materials and architectural treatment. 
13.3 Provide incentives to private owners of historic resources to maintain and/or enhance their properties in a manner that will conserve the integrity of such resources in the best possible condition.

13.4 Promote community appreciation for the unique history of the San Clemente area and community involvement in its retention and preservation.

13.5 Commemorate San Clemente's historical significance as location of "The Western White House."

13.6 The updated list of historic properties in San Clemente shall be sent to the State Historic Preservation Officer (SHPO). Liaison between SHPO and the City of San Clemente relative to cultural/historic structures and properties shall be maintained.

13.7 The City Council shall initiate the proceedings for inclusion on the National Register of Historic Places, any historic site of potential national significance, should any such sites be identified.

13.8 Emphasize the protection, enhancement, and sensitive development of park and open space areas which possess great scenic, environmental, historic, and cultural values.

13.9 We provide leadership in the field of historic preservation by preserving and adaptively reusing City-owned historic resources in compliance with the Secretary of the Interior's Standards for the Treatment of Historic Properties and other standards and guidelines as prescribed by the State Office of Historic Preservation.

13.10 Through the City of San Clemente Municipal Code, we require owners of historic resources to maintain their property to preserve its historic integrity.

13.11 We require mitigation of significant, adverse impacts to onsite and nearby historic resources as part of applications for general plan amendments, zoning changes, or any projects requiring environmental review per the California Environmental Quality Act (CEQA).

13.12 We encourage adaptive reuse of historic resources to preserve historic resources and prevent architecturally inappropriate changes, disrepair and demolition.

13.13 We ensure projects follow the Secretary of Interior Standards for the Treatment of Historic Properties and standards and guidelines as prescribed by the State Office of Historic Preservation for any listed historic resources or properties eligible for historic listing. 
13.14 We require that new development adjacent to or within a 300-foot radius from a historic resource be compatible with the historic resource in terms of scale, massing, building materials and general architectural treatment.

13.15 We apply flexible development standards where appropriate and necessary to help preserve historic integrity and character of buildings and sites and comply with zoning regulations. In the event of an earthquake, flood or other natural disaster we take all reasonable steps to promote the preservation, repair and restoration of damaged historic structures. If a historic building is damaged so that it is physically infeasible to restore, we require the replacement building to reflect the former building's architectural character. We incorporate historic and cultural preservation as an integral part of planning, development and environmental review.

\subsection{Water and Marine Resources Goals and Policies}

Coastal Act policies (PRC 30230 and 30231) require the preservation, enhancement and restoration of water and marine resources. Coastal water and marine resources include: the ocean, the beach and flood control channels. The marine environment serves as both a recreational and visual resource, as well as a habitat for marine life. The City is committed to the preservation of water and marine resources to ensure a clean and health marine environment for beach users, and to maintain and enhance habitat to support local populations of sea life.

\section{Policy Intent}

Plan policy provides for maintaining a safe and healthy beach and marine environment for beach users and populations of all local marine species.

\section{Goal}

14. Provide and maintain a safe and healthy beach environment for beach users and the local marine life.

\section{Policies}

Coastal Resources

14.1 Marine resources shall be maintained, enhanced, and where feasible, restored. Special protection shall be given to areas and species of special biological or economic significance. Uses of the marine environment shall be carried out in a manner that will sustain the biological productivity of coastal waters and that will maintain healthy populations of all species of marine organisms adequate for long term commercial, recreational, scientific and educational purposes (PRC 30230). 
14.2 The biological productivity and the quality of coastal waters,... appropriate to maintain optimum populations of marine organisms and for the protection of human health shall be maintained and, where feasible, restored through, among other means, minimizing adverse effects of wastewater discharges and entrainment, controlling runoff, preventing; depletion of ground water supplies and substantial interference with surface water flow and encouraging wastewater reclamation (PRC 3023 1).

14.3 The diking, filling or dredging of open coastal waters, wetlands, estuaries, and lakes shall be permitted in accordance with other applicable provisions of the California Coastal Act and the City of San Clemente Land Use Plan, where feasible mitigation measures have been provided to minimize adverse environmental effects, and shall be limited to the following:

1) In open coastal waters, for new or expanded boating facilities and/or placement of structural pilings for public recreational piers that provide public access and public recreational opportunities.

2) Incidental public service purposes, including, but not limited to, burying cables and pipes or inspection of piers and maintenance of existing intake and outfall lines.

3) Mineral extraction on City beaches shall be prohibited except for sand uses for restorative purposes.

4) Restoration purposes.

5) Nature study, aquaculture, or similar resource dependent activities

Dredging and soils disposal shall be planned and carried out to avoid significant disruption to marine and wildlife habitats and water circulation. Dredge soils suitable for beach replenishment should be transported for such purposes to appropriate beaches or into suitable longshore current systems.

Revetments, breakwaters, groins, harbor channels, seawalls, cliff retaining walls, and other such construction that alters natural shoreline processes shall be permitted when required to serve coastal dependent uses or protect existing structures or public beaches in danger from erosion and when designed to eliminate or mitigate adverse impact on local shoreline sand supply. Existing marine structures causing water stagnation contributing to pollution problems and fish kills should be phased out or upgraded, where feasible (PRC 30235).

City

14.4 Provide a clean and enjoyable beach and marine environment that meets the needs of beach users.

14.5 Maintain and enhance the City's beaches and marine resources. 
14.6 Continue monitoring sand movement, researching the impacts of coastal erosion and methods of mitigating further coastal damage to San Clemente's beaches environment.

14.7 Maintain a healthy coastline, preventing degradation of the community's visual and environmental resources.

14.8 Continue to actively oppose off shore oil drilling of ocean waters along the Pacific Coast where visual and environmental quality have the potential to be severely impacted for residents and beach users .

14.9 Continue to support the creation of a wildlife sanctuary for various habitats along the coast to preserve and protect the natural beach environment while preserving recreational sport fishing opportunities.

14.10 Permit extraction of significant mineral resources, such as borrow material that may be used for beach replenishment, as an interim use prior to development.

14.11 Despite the fact that much of the responsibility for protection of water resources lies with regional and state agencies, there are several measures the City can take to help further protect coastal waters. These include the following:

1) The City shall establish a water monitoring program, if necessary, for selected target areas in the Coastal Zone to ensure water and marine resources are adequately protected.

2) The City shall encourage reduction in storm drain related pollution by requiring baffled catch basins in large scale new developments and require their proper maintenance where drainage could damage sensitive areas.

3) The City shall promote increased water conservation by requiring conservation measures in the design of new projects in the Coastal Zone.

4) The City shall encourage utilization of urban pollutant control devices such as street sweeping, litter removal, irrigation, fertilizer and insecticide control, and landscape debris removal.

5) The City shall require use of landscape materials which impede erosion on sloped surfaces.

6) The City shall encourage use of native plant species for landscaping to minimize water consumption, fertilization and chemical application, and to visually relate development to existing natural landscape.

7) The City shall require that construction be conducted with provisions for the control of sediment transport and debris originating at the construction site as follows:

a. For necessary grading operations, the smallest practical area of land will be exposed at any one time during development, and the length of exposure will be kept to the shortest practical amount of time. The clearing of land should be avoided during the winter rainy season and all measures for removing sediments and stabilizing slopes should be in place before the beginning of the rainy season. 
b. Sediment basins (including debris basins, desilting basins or silt traps) will be installed in conjunction with the initial grading operations and maintained through the development process to remove sediment from runoff waters. All sediment shall be retained on site unless removed to an appropriate dumping location.

c. Temporary vegetation, seeding, mulching or other suitable stabilization methods will be used to protect soil subject to erosion that has been disturbed during grading or development. All cut and fill slopes shall be stabilized immediately with planting of native grasses and shrubs, appropriate nonnative plants, or with accepted landscaping practices.

d. Provisions will be made to conduct surface water to storm drains or suitable watercourses to prevent erosion. Drainage devices shall be designed to accommodate increased runoff resulting from modified soil and surface conditions as a result of development.

8) The construction of revetments, breakwaters, groins, harbor channels, seawalls, cliff retaining walls and other protective devices are discouraged and shall be permitted only when such construction is required to serve coastal dependent uses or to protect existing structures or public beaches in danger from erosion. In no way shall such structures prohibit or impact coastal access, beaches or coastal recreational areas.

14.12 Require that uses of and in the marine environment be conducted to 1) maintain the long-term biological productivity of coastal waters, 2) ensure the continuation of a healthy, self-renewing marine ecosystem, and 3) help ensure the long-term survival of healthy populations of marine plants and animals.

14.13 Provide a litter-free and enjoyable beach and marine environment and protect the natural resources found in the Coastal Zone by evaluating new development proposals, as required under the California Environmental Quality Act and as described in the Local Coastal Program Implementation Plan.

14.14 Protect our coastal and marine resources by implementing the City's Stormwater Management Program or Urban Runoff Management Program as described in Municipal Code (Chapter 13.40), in compliance with Federal, State and regional requirements.

14.15 Ensure landscaping within the Coastal Zone uses primarily plants that are native to the local region and consistent with Orange County Fire Authority and California Coastal Commission approved plant list for fuel modification zones.

14.16 Recognize and protect wetlands for their scenic, commercial recreational, water quality, and habitat values.

14.17 Work with the state and federal resource protection agencies, business and private organizations and individuals to protect our natural and marine resources.

14.18 See to prevent the introduction, reproduction or spread of non-native plant and animal species through public education, maintenance of marine facilities and by assisting local, state and federal agencies enforce laws protecting marine resources. 
14.19 Maintain a comprehensive urban runoff management plan to minimize stormwater impacts on our watershed, beaches and marine resources.

14.20 Ensure that existing and new development does not degrade San Clemente's water resources.

14.21 Review City policies, codes, development fees and service charges to ensure best management practices are utilized to conserve water and ensure that there is adequate funding to support the operations, maintenance, and development of water and wastewater facilities and services.

14.22 Require new and existing operations that involve the use or creation of toxic substances and hazardous materials to control their operations and adequately dispose of these materials to prevent degradation of our water resources.

14.23 Prohibit the use of septic systems in San Clemente.

14.24 Provide and maintain adequate water supplies and distribution facilities capable of meeting existing and future daily and peak demands, including fire flow requirements (link to Safety Element, Fire section).

14.25 Strategically plan for an adequate water supply and distribution system by maintaining and updating the Urban Water Management Plan.

14.26 Use public education to promote rebate programs, water conservation, and household strategies to minimize impacts to water quality (e.g., disposal methods for fats, grease and oils).

14.27 Encourage, and in some cases require the use of recycled water when available, and encourage the use of domestic greywater, for landscape irrigation and other nonpotable, non-contact uses and to maintain landscaping and encourage the extension of recycled water facilities to serve all areas.

14.28 Provide and maintain a system of wastewater collection and treatment facilities to adequately convey and treat wastewater generated in the City of San Clemente service area.

14.29 Monitor wastewater treatment usage and capacity to plan for wastewater infrastructure improvements or new facilities.

14.30 Require the use of low-impact site development designs and strategies to slow urban runoff, improve filtration, and reduce the volume of discharges through best management practices. 
14.31 In coordination with other agencies, enforce local plans and state and federal requirements for stormwater runoff management and mitigation to protect our water quality.

14.32 To conserve water, we require the use of drought-tolerant landscaping, consisting of at least 60 percent (by landscaped area) California Native plants, in new development and encourage its use in existing development.

\subsection{Environmentally Sensitive Habitat Goals and Policies}

Coastal Act policy (PRC 30240) requires that environmentally sensitive habitat areas shall be protected. Environmentally sensitive habitat areas in San Clemente's Coastal Zone include wetlands, riparian areas, habitats of rare or endangered species, and several coastal canyons which still contain native plant communities.

The five coastal canyons contain important natural habitat areas. Development of land in and adjacent to the canyons is subject to the canyon preservation policies noted in this plan. The Marblehead Coastal site also has a variety of sensitive habitat areas that are protected as part of the adopted Marblehead Coastal Specific Plan.

\section{Policy Intent}

Plan policy provides for the protection and preservation of environmentally sensitive habitats within the Coastal Zone.

\section{Goal}

15. Protect and preserve significant plant and wildlife species which exist in the City's Coastal Zone.

\section{Policies}

Coastal Act

15.1 Encourage activities which improve the natural biological value, integrity and corridor function of the coastal canyons through vegetation restoration, control of alien plants and animals, and landscape buffering.

15.2 Environmentally sensitive habitat areas shall be protected against any significant disruption of habitat values, and only uses dependent on such resources shall be allowed within such areas. "Environmentally sensitive area" means any area in which plant or animal life or their habitats are either rare or especially valuable because of 
their special nature or role in an ecosystem and which could be easily disturbed or degraded by human activities and developments (PRC 30240(a)).

15.3 Development in areas adjacent to environmentally sensitive habitat areas and parks and recreation areas shall be sited and designed to prevent impacts which would significantly degrade such areas, and shall be compatible with the continuance of such habitat areas (PRC 30240(b)).

City

15.4 Designate lands for the protection of significant environmental resources and protection of life and property from environmental hazards on the Coastal Land Use Plan Map.

15.5 Balance the preservation of the City's habitat areas with new development.

15.6 Require that applications for development in the areas which an Initial Study has determined there is potential for significant adverse impacts to biological resources [therefore requiring an Environmental Impact Report (EIR) or Mitigated Negative Declaration (MND)] shall include a Biological Assessment Report which:

1) Is prepared by a qualified professional which addresses the proposed project's impact on state and federally listed and candidate plants and animals; California Department of Fish and Game (CDFG) Special Animals; natural communities of high inventory priority with the CDFG's Nongame Heritage Program, and any other special interest species or communities identified in the General Plan Technical Background Report, or those hereafter named by state or federal trustee agencies;

2) Identifies mitigation measures necessary to eliminate significant adverse impacts to sensitive biological resources; and

3) Defines a program for monitoring and evaluating the effectiveness of the specified mitigation measures.

15.7 Review of all projects within the Coastal Zone shall include an assessment of the potential impact on natural habitat areas.

15.8 The City shall pursue grants and other funding sources to perform a biological study of the designated natural habitat areas in the Coastal Zone.

15.9 Review of all development projects located adjacent to parks and recreation areas shall include a site plan and elevation which depicts any potential impact on coastal canyons. The elevation shall be prepared by a certified architect or engineer.

15.10 The analysis and evaluation of large scale development projects shall include a comprehensive inventory of biologic resources prepared by a qualified biologist. A 
determination should be made of the area's importance as a native habitat, including identification of rare and endangered species.

15.11 Mitigation measures identified during site plan review stages to limit a project's effect on the coastal canyon environment shall be incorporated into final project design plans.

15.12 Geotechnical review will be required on all blufftop and canyon edge parcels. If, as a result of geotechnical review, a greater setback is recommended than is required in the policies in this Plan, the greater of the setbacks shall apply.

15.13 The removal of native vegetation and the introduction of non native vegetation in the canyons shall be minimized. The use of native plant species in and adjacent to the canyons shall be encouraged.

15.14 Any subdivision of property in or adjacent to coastal canyons shall be reviewed for consistency with the coastal canyon preservation policies. New parcels that do not have an adequate building site area to comply with the setback standards of these policies shall not be created.

15.15 Identify the key beach areas which are important to protect through land use regulation because of their inherent environmental, ecological, and/or aesthetic contributions.

15.16 Maintain the presence of parklands and open space in the Coastal Zone in order to conserve and enhance the natural environment thereby improving the quality and livability of the City of San Clemente.

15.17 Identify those major areas of the City which are important to protect through land use regulation or public ownership because of their inherent environmental, ecological, and/or aesthetic contribution to the scenic and natural qualities of San Clemente.

15.18 Operate and maintain San Clemente Park and Recreation facilities through programs that are designed for the most effective use and enhancement of the park site at the minimum possible cost.

15.19 Prohibit development and grading which alters the biological integrity of the Riparian Corridors unless no environmentally acceptable alternative exists or it is replaced with habitat of equivalent value. 


\section{CHAPTER 4: IMPLEMENTATION MEASURES}

\subsection{Overview of Coastal Implementation Measures}

The Coastal Act requires cities to develop a Coastal Implementation Program that will implement the requirements of the Coastal Act and the goals and policies of a local jurisdiction's Land Use Plan. This chapter identifies a variety of documents and programs that will be used in implementing the City of San Clemente Land Use Plan.

The implementation measures in Chapter 4 are divided into sections including: land use, shoreline access, recreational and visitor-serving facilities, visual and historic resources, water and marine resources, environmentally sensitive habitats and general implementation. These sections correspond to the goals and policy sections in Chapter 3.

(Implementation measures to be added following General Plan adoption)

\subsection{Land Use}

4.3 Shoreline Access

4.4 Recreational and Visitor-Serving Facilities

4.5 Visual and Historic Resources

4.6 Water and Marine Resources

4.7 Environmentally Sensitive Habitats

4.8 General Implementation 


\section{CHAPTER 5: DEFINITIONS}

For the purpose of the Land Use Plan, certain terms shall be defined as set forth in this chapter. Terms not included shall be defined by the California Coastal Act or in the City of San Clemente General Plan, or if not listed, shall be construed in accordance with Chapter 17.88 of the San Clemente Municipal Code, or if not defined herein, with accepted usage. Words used in the present tense shall include the future; words in the singular shall include the plural; the words "will" and "shall" are mandatory and the word "may" is permissive. The word "should" refers to policy guidance which must be followed in the absence of compelling, opposing considerations identified by the City. The City Planner or his designee shall interpret the meaning and intent of minor definitions if ambiguity, and the Planning Commission does major interpretations if inconsistency or conflict exists.

For the purposes of the Coastal Zone, the following definitions shall apply:

1. "ACTIVE RECREATIONAL AREA" means an area used for a variety of intense uses such as, but not limited to basketball, tennis, volleyball, softball, soccer or other recreational or sports activities.

2. "ADJACENT STRUCTURE" means a structure located on a lot contiguous (sharing a property line) with the proposed structure or development.

3. "AGGRIEVED PERSON" means any person or representative who appeared at a public hearing, or by other appropriate means prior to action on a Coastal Development Permit, informed the City of his or her concerns about an application for such permit, or any person who, for good cause, was unable to do either, of the foregoing objects to the action taken on such permit and wishes to appeal such action to a higher authority.

4. "APPEALABLE AREA" means the area identified on the Local Coastal Program Post Certification Map as "Appeal Jurisdiction."

5. “APPLICANT" means any person, partnership, corporation, or state or local government, agency applying for a Coastal Development Permit.

6. "APPROVING AUTHORITY" means the City Planner, City Council, Planning Commission, or Zoning Administrator approving a Coastal Development Permit.

7. "BEACH" means a sandy, gravel or rocky portion of land along the edge of the ocean.

8. "BEACH FRONT" means an area of land that is adjacent to the beach and the edge of the ocean. 
9. “CERTIFIED LAND USE PLAN LAND USE PLAN (LUP)" means a plan for the use of property within the Coastal Zone which has been adopted by the local government and certified by the California Coastal Commission pursuant to the California Public Resources Code.

10. "CERTIFIED LOCAL COASTAL PROGRAM (LCP)" means a program for the use of property within the Coastal Zone. The Local Coastal Program includes the Land Use Plan and specific regulations, and land use regulation maps, which have been adopted by the local government and certified by the California Coastal Commission pursuant to the Public Resources Code. Local governments with certified LCPs can issue Coastal Development Permits.

11. "COASTAL ACCESS" means an area dedicated to provide public access to the beach or for public viewing of the shoreline.

12. “COASTAL ACT" means the California Coastal Act of 1976, as amended.

13. "COASTAL BLUFF" means any landform that has vertical relief of ten feet or more that is adjacent to the coast.

14. "COASTAL CANYON" means any valley, or similar landform which has a vertical relief of ten feet or more.

15. "COASTAL CLIFF" means any steep vertical landform which has a vertical relief of ten feet or more.

16. “COASTAL BLUFF, CANYON, CLIFF FACE” means a sharp or steep face of rock, decomposed rock, sediment or soil resulting from erosion, faulting, folding, uplifting or excavation of the land mass. The canyon or bluff face may be a simple planar or curved surface or it may be step-like in section (Refer to Figure 15-1).

17. "COASTAL COMMISSION" means the California Coastal Commission.

18. “COASTAL-DEPENDENT DEVELOPMENT OR USE" means any development or use that requires a site-on, or adjacent to, the sea to be able to function at all.

19. “COASTAL DEVELOPMENT PERMIT" means a discretionary entitlement which is required of development in specified areas of the Coastal Zone to ensure that such development is consistent with the City of San Clemente Land Use Plan.

20. "COASTAL LANDFORM" means coastal topographic features that form the landscape of the coastal zone. These features include: canyons, bluffs, cliffs, terraces, foothills, and other similar landforms. 
21. "COASTAL-RELATED DEVELOPMENT" means any use that is dependent on a coastaldependent development or use.

22. "COASTAL SAGE SCRUB" means vegetation which include, but are not limited to, the following: many species of Dudleya, Calandrinia maritima, Cleome isomeris, Coreopsis gigantea, Eriogonum giganteum, Eriogonum grande, Eriophyllum nevinii, Galvesia speciosa, Haplopappus venetus, Hemizonia clementina, Lavatera assurgentiflora, Malacothrix saxatilis, Phacelia lyonii, and Rhus integrifolia, plus two species of Polypodium, Artemisia californica, Crossosoma californicum, Diplacus species, Encelia californica, Eriogonum fasciculatum, Galium, Haplopappus, Helianthemum, Lotus, Lupinus, Malacothamnus, and Opuntia species, Malosma laurina, Salvia spp., Senecio, and Solanum species, and Toxicodendron radicans diversilobum, the sprawling Marah macrocarpus and Calystegia macrostegia, and many other showy herbs like species of Castilleja, Haplopappus, Lotus, Lupinus, and Zauschneria, and Eriophyllum confertiflorum.

23. "COASTAL ZONE" means that land and water area of the City of San Clemente, as described in California Public Resources Code Section 30170 and amendments thereto, and as delineated on the Coastal Zone Boundary Map (Refer to the coastal boundary indicated on the "Zoning Map of the City of San Clemente").

24. "CUMULATIVE EFFECT" means the incremental effects of an individual project reviewed in connection with the effects of past projects, the effects of other current projects and the effects of probable future projects.

25. "DEVELOPMENT, COASTAL" means the placement or erection, on land, in or under water, of any solid material or structure; discharge or disposal of any dredged material or of any gaseous, liquid, solid, or thermal waste; grading, removing, dredging, mining, or extraction of any materials; change in the density or intensity of use of land, including, but not limited to, subdivision pursuant to the Subdivision Map Act (commencing with Section 66410 of the California Government Code), and any other division of land, including lot splits, except where the land division is brought about in connection with the purchase of such land by a public agency for public recreational use; change in the intensity of use of water, or of access thereto; construction, reconstruction, demolition, or alteration of the size of any structure, including any facility of any private, public, or municipal utility; and the removal or harvesting of major vegetation other than for agricultural purposes, kelp harvesting, or timber operations which are in accordance with a timber harvesting plan submitted pursuant to the provision of the Z'berg-Nejedly Forest Practice Act of 1973 (commencing with Section 45.11). 
26. "EDGE" means the upper termination of a bluff, canyon, or cliff. When the top edge is rounded away from the face as a result of erosional processes related to the presence of the steep bluff, canyon, or cliff face, the edge shall be defined as that point nearest the face beyond which the downward gradient of the land surfaces increases more or less continuously until it reaches the general gradient of the bluff, canyon, or cliff. In a case where there is a step-like feature at the top of the bluff face, canyon, or cliff face, the landward edge of the topmost riser shall be taken as bluff edge, canyon edge, or cliff edge (refer to Figure 17.60.050(B).

27. "EMERGENCY" means sudden, unexpected occurrence demanding immediate action to prevent or mitigate loss of or damage to life, health, property or essential public services.

28. "ENVIRONMENTALLY-SENSITIVE HABITAT AREA" means any area in which plant or animal life or their habitats are either rare or especially valuable because of their special nature or role in an ecosystem and which could be easily disturbed or degraded by human activities and developments.

Environmentally-sensitive habitat areas in San Clemente's Coastal Zone include wetlands, riparian areas, habitats of rare or endangered species and several coastal canyons which still contain native plant communities. The environmentally sensitive habitat areas are depicted on the "Environmentally Sensitive Habitat Areas" Map of the City's Land Use Plan. The canyons contain important natural habitat areas. Development of land in and adjacent to the canyons is subject to the canyon-preservation policies noted in the City of San Clemente Land Use Plan. The canyons are as follows: Palizada canyon, Trafalgar canyon, Toledo canyon, Lobos Marinos canyon, Riviera canyon, Montalvo canyon, and Calafia canyon (See Figure 2.3: Coastal Canyons).

29. "EXECUTIVE DIRECTOR" means the Executive Director of the California Coastal Commission.

30. "FIRST PUBLIC ROADWAY" means the nearest through public access route (open to vehicular traffic) paralleling the ocean shoreline, which forms a continuous linkage from the northernmost to the southernmost limits of the City of San Clemente shoreline.

31. "INTENSIFICATION OF USE" means a change in the use of a lot or premises which, based upon the provisions of the underlying zone, requires more off-street parking than did the immediately prior legal use of such lot or premises.

32. "LATERAL ACCESS" means an area of land providing a connection parallel to the beach, along the beach front, toe of bluff or top of bluff. A lateral accessway may be used for 
public pass and repass, passive recreational use, or as otherwise designated in the City of San Clemente Local Coastal Program Land Use Plan.

33. "MAJOR ENERGY FACILITY" means any energy facility as defined by the California Public Resources Code Section 30107 and exceeding $\$ 50,000$ in estimated cost of construction.

34. "MAJOR PUBLIC WORKS PROJECT" means any public works project as defined by the California Code of Regulations Section 13012 and exceeding $\$ 50,000$ in estimated cost of construction.

35. "NATIVE VEGETATION" means vegetation composed of plants which originated, developed, or were produced naturally in the Southern Orange County coastal region and were not introduced directly or indirectly by humans. Native vegetation includes, but is not limited to: marsh vegetation, native grasslands, coastal/inland sage scrub, and oak and riparian woodlands.

36. "PASSIVE RECREATIONAL AREA" means areas used primarily for non-active type of uses such as open quiet areas, walking paths, stationary benches, picnic facilities and hiking and riding trails.

37. "PRIMARY VEGETATION LINE" means one development setback standard that may be utilized for coastal canyons. Characteristics to be established based on an on-site visit, and inventory of existing vegetation and topography.

38. "PUBLIC BENEFIT COASTAL" means project elements that are related to coastal recreation or resources, provide a physical or aesthetic benefit to the public and restore or enhance coastal resources. Examples include but are not limited to public access to the beach, coastal recreational trail, passive and active recreational parks, habitat restoration and public viewing areas.

39. "PUBLIC VIEW" means any publicly accessible location on dedicated or publicly owned property, including but not limited to, roadways, parks, and cultural or recreational facilities, which affords a view to the public of the ocean, a canyon or hillside area, ESHA, or any other open-space area identified in the General Plan, Zoning Ordinance or Specific Plan.

40. "PUBLIC WORKS" means public facilities and infrastructure, including:

1. All production, storage, transmission, and recovery facilities for utilities subject to the jurisdiction of the California Public Utilities Commission, except for energy facilities; 
2. All public transportation facilities, including streets, roads, highways, mass transit facilities and stations and bridges, public parking lots and structures, ports, harbors, airports, railroads, and other related facilities;

3. All publicly financed recreational facilities; and

4. All community college facilities.

41. "RIPARIAN VEGETATION" means an environment associated with plant communities which require high soil moisture conditions maintained by transported fresh water in excess of that otherwise available through local precipitation.

42. "SEA" means the Pacific Ocean and all harbors, bays, channels, estuaries, salt marshes, sloughs, and other areas subject to tidal action through any connection with the Pacific Ocean, excluding nonestuarine rivers, streams, tributaries, creeks, and flood-control and drainage channels.

43. "STREAM" means a natural watercourse identified as a stream on a map adopted pursuant to a certified Local Coastal Program; or as designated by a solid blue line or other symbol on the USGS 7.5 minute quadrangle series map. The bank of the stream shall be defined as the watershed and relatively permanent elevation or acclivity at the outer line of the stream channel which separates the bed from the adjacent upland, whether valley or hill, and serves to confine the water within the bed and to preserve the course of the stream. In areas where the stream has no discernible bank, the boundary shall be measured from the line closest to the stream where riparian vegetation is permanently established.

44. "STRINGLINE" means in a developed area where new construction is generally infilling and is otherwise consistent with the policies of the Land Use Plan of the City of San Clemente Local Coastal Program, no part of a proposed new structure, including decks, shall be built further toward a bluff edge, canyon edge or beach-front than a line drawn between the nearest adjacent corners of the adjacent structures.

45. "STRUCTURE" means any physical construction, including but not limited to, any building, road, pipe, flume, conduit, siphon, aqueduct, telephone line, and electrical power transmission and distribution line.

46. "SUBMERGED LANDS" means lands that lie below the line of mean low tide.

47. "TIDELANDS" means lands that are located between the line of mean high tide and mean low tide.

48. "TOE" means the lowest part of an embankment. 
49. "VERTICAL ACCESS" means an area of land providing a connection between the first public roadway or use area nearest the sea and the publicly-owned tidelands or established lateral accessway. A vertical accessway may be used for public pass and repass, passive recreational use, or as otherwise designated in the City of San Clemente Local Coastal Program Land Use Plan.

50. "WETLANDS" means land within the Coastal Zone which may be covered periodically or permanently with shallow water, and including salt water marshes, freshwater marshes, open or closed brackish water marshes, swamps, mud flats, and fens. 